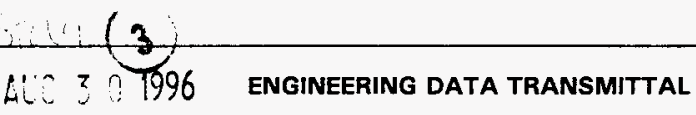

\begin{tabular}{|l|l|}
\hline $\begin{array}{l}\text { 2. To: (Receiving organization) } \\
\text { Distribution }\end{array}$ & $\begin{array}{l}\text { 3. From: coriginating organization) } \\
\text { Data Assessment and } \\
\text { Interpretation }\end{array}$ \\
\hline $\begin{array}{l}\text { 5. Proj./Prog./Dept./Div.: } \\
\text { Tank 241-BY-105/Waste } \\
\text { Management/DAI/TWRS } \\
\text { Technica 1 Basis }\end{array}$ & $\begin{array}{l}\text { 6. cog. Engr.: } \\
\text { Brett C. Simpson }\end{array}$ \\
\hline $\begin{array}{l}\text { 8. originator Remarks: } \\
\text { This document is being released into the supporting document } \\
\text { system for retrievability purposes. }\end{array}$
\end{tabular}

11. Receiver Remarks:

For release.
Not co buikene document
4. Related EDT NO.:

$N / A$

7. Purchase Order No.:

$N / A$

9. Equip./Component No.:

$N / A$

10. System/Bldg./Facility: $241-B Y-105$

12. Major Assm. Dwg. No.: $N / A$

13. Permit/Permit Application No.: $\mathrm{N} / \mathrm{A}$

14. Required Response Date: $08 / 14 / 96$

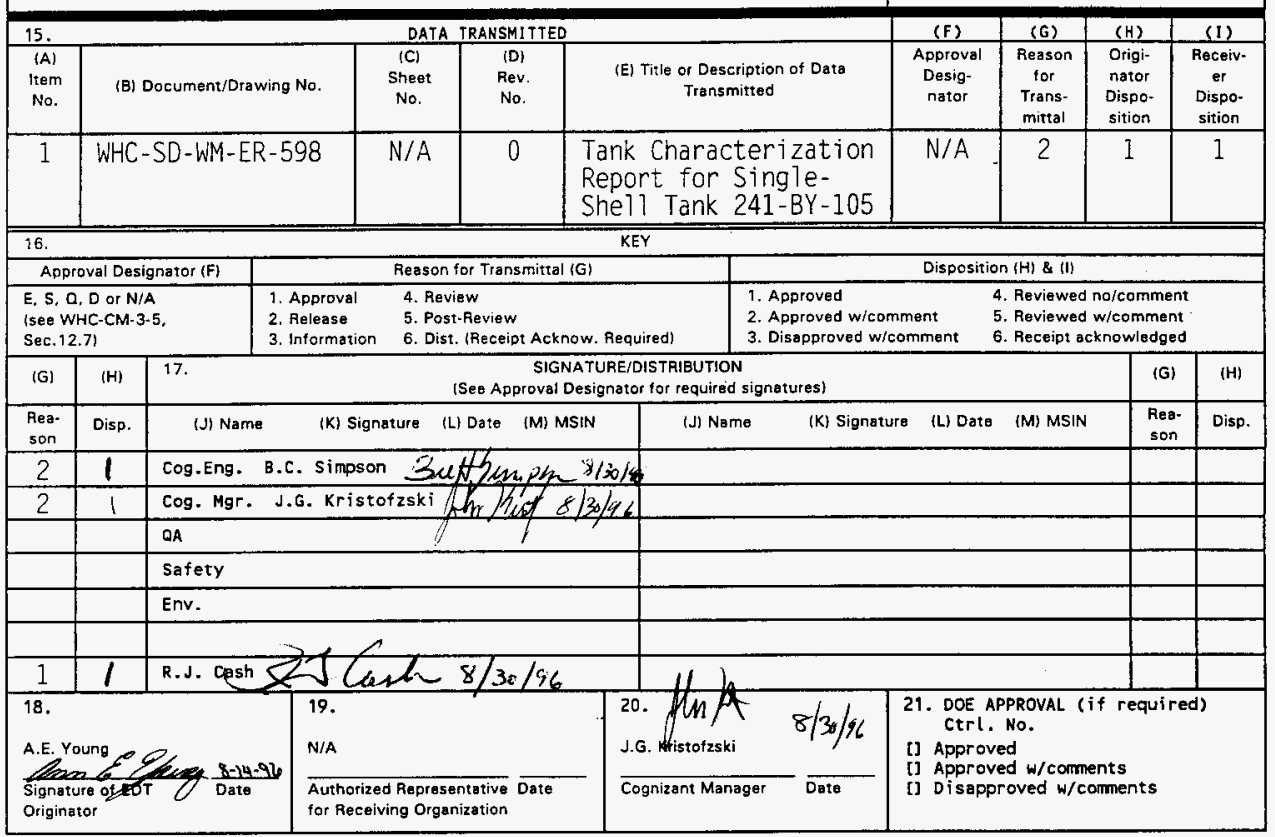




\section{Tank Characterization Report for Single-Shell Tank 241-BY-105}

Brett C. Simpson

Westinghouse Hanford Company, Richland. WA 99352

U.S. Department of Energy Contract DE-AC06-87RL10930

$\begin{array}{lll}\text { EDT/ECN: } & \text { EDT }-617521 & \text { UC: } 2070 \\ \text { Org Code: } & 79400 & \text { Charge Code: N4G4D } \\ \text { B\&R Code: } & \text { EW } 3120074 & \text { Total Pages: } 36\end{array}$

Key Words: Tank 241-BY-105, BY Farm, Tank Characterization Report. TCR. Single-She 11 Tank. SST. Waste Inventory. TPA Milestone M-44.

Abstract: This document summarizes the information on the historical uses, present status, and the sampling and analysis results of waste stored in Tank 241-BY-105. Sampling and analyses were completed to meet Safety Screening. Ferrocyanide and Historical Data Quality Objectives. This report supports the requirements of Tri-Party Agreement Milestone M-44-09.

TRADEMARK DISCLAIMER. Reference herein to any specific comercial product, process, or service by trade name, trademark, manufacturer, or otherwise, does not necessarily constitute or imply its endorsement, recommendation, or favoring by the United States Government or any agency thereof or its contractors or subcontractors.

Printed in the United States of America. To obtain copies of this document, contact: WHC/BCS Document Control Services, P.0. Box 1970, Mailstop H6-08, Richland WA 99352, Phone (509) 372-2420; Fax (509) 376-4989.
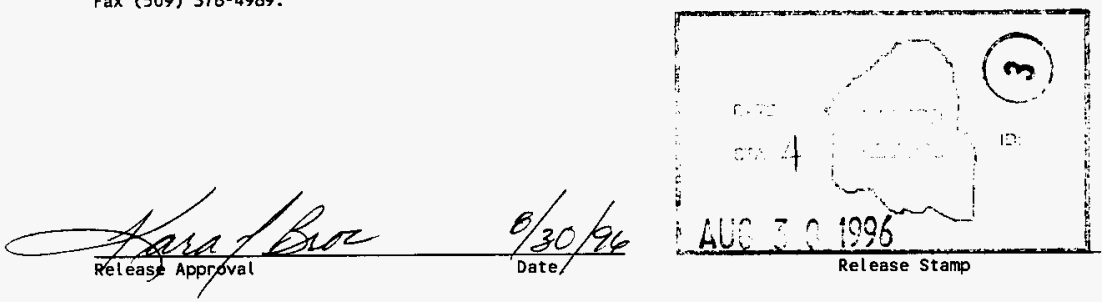

\section{Approved for Public Release}




\title{
Tank Characterization Report for Single-Shell Tank 241-BY-105
}

\author{
B. C. Simpson \\ J. G. Field \\ L. M. Sasaki
}

Date Published

August 1996

Prepared for the U.S. Department of Energy

Assistant Secretary for Environmental Management

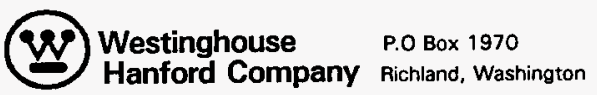

Management and Operations Contractor for the

U.S. Department ôf Energy under Cóntract DE-ACO6-87RL70930

Approved for public release; distribution is unlimited 


\section{EXECUTIVE SUMMARY}

This tank characterization report summarizes information on the historical uses, current status, and recent sampling and analysis results of waste stored in single-shell underground tank 241-BY-105. This report supports the requirements of the Hanford Federal Facility Agreement and Consent Order (Ecology et al. 1996), Milestone M-44-09 and the Ferrocyanide Safety Program, Milestone T22-96-020 (WHC 1995b). According to the analyses addressed by this report, tank 241-BY-105 does not raise safety concerns based on the decision limits of the safety screening data quality objectives (DQO) (Sasaki 1996a and 1996b). However, the sampling and analysis effort associated with this tank is incomplete.

Tank 241-BY-105 is one of 12 single-shell underground waste storage tanks located in the 200 East Area BY Tank Farm on the Hanford Site. Tank 241-BY-105 began receiving metal waste through a cascade during the second quarter of 1951 . In the third quarter of 1954 , the metal waste was sluiced for uranium recovery. In the fourth quarter of 1954 , the tank started receiving ferrocyanide waste from tanks $241-\mathrm{BY}-107$ and $241-\mathrm{BY}-110$. Until the second quarter of 1956 , the tank received ferrocyanide waste intermittently from all of the ferrocyanide settling tanks. From 1954 to 1957 and 1971 to 1974 , the tank occasionally received flush water from miscellaneous sources (Agnew et al. 1996). Tank 241-By-105 received PUREX cladding waste from tanks.241-C=108 and $241-C-107$ in 1961. From the second to the fourth quarter of 1966 , additional cladding waste was sent to the tank. Also in 1966, 63 tons of Portland cement was added as part of a tank solidification pilot operation. 
From the last half of 1967 to the fourth quarter of 1974, the tank received in-tank solidification bottoms waste.

Table ES-1 and Figure ES-1 describe tank 241-BY-105 and its status. The tank has an operating capacity of $2,870 \mathrm{~kL}$ (758 kgal) and presently contains $1,904 \mathrm{~kL}$ (503 kgal) of waste. There are approximately $598 \mathrm{~kL}$ (158 kgal) of sludge and 1,306 kL (345 kgal) of saltcake. No supernatant liquid remains. These values are based on surveillance information and historical data (Hanlon 1996, Grigsby et al. 1992, and Agnew et al. 1996). Section 2.4 discusses sludge and saltcake inventory differences from Hanlon (1996). The sludge is estimated to contain $727 \mathrm{~kL}$ (192 kgal) of drainable interstitial liquid. Waste surface level measurements have remained relatively constant for three years. Tank 241-BY-105 is on the Ferrocyanide Watch List, and it potentially contains organic complexants (WHC 1995a).

The characterization of tank 241-BY-105 is based on three sampling events: a two-part vapor sampling event that took place in May and July 1994, a grab sampling event that took place on March 22, 1995, and a core sampling event that took place between August 29 and October 6, 1995.

During the March, 1995 grab sampling event, two liquid grab samples were obtained from riser 5. Sampling.and.analysis were conducted in accordance with Data Quality and Objectives for the Waste Compatibility Program (Fowler 1995) and Tank 241-BY-105 Tank Characterization Plan (Schreiber 1995). Analyses included volume percent solids, specific gravity, energetics, radionuclides, and selected metals and anions. The results compared 
Table ES-1. Description and Status of Tank 241-BY-105.

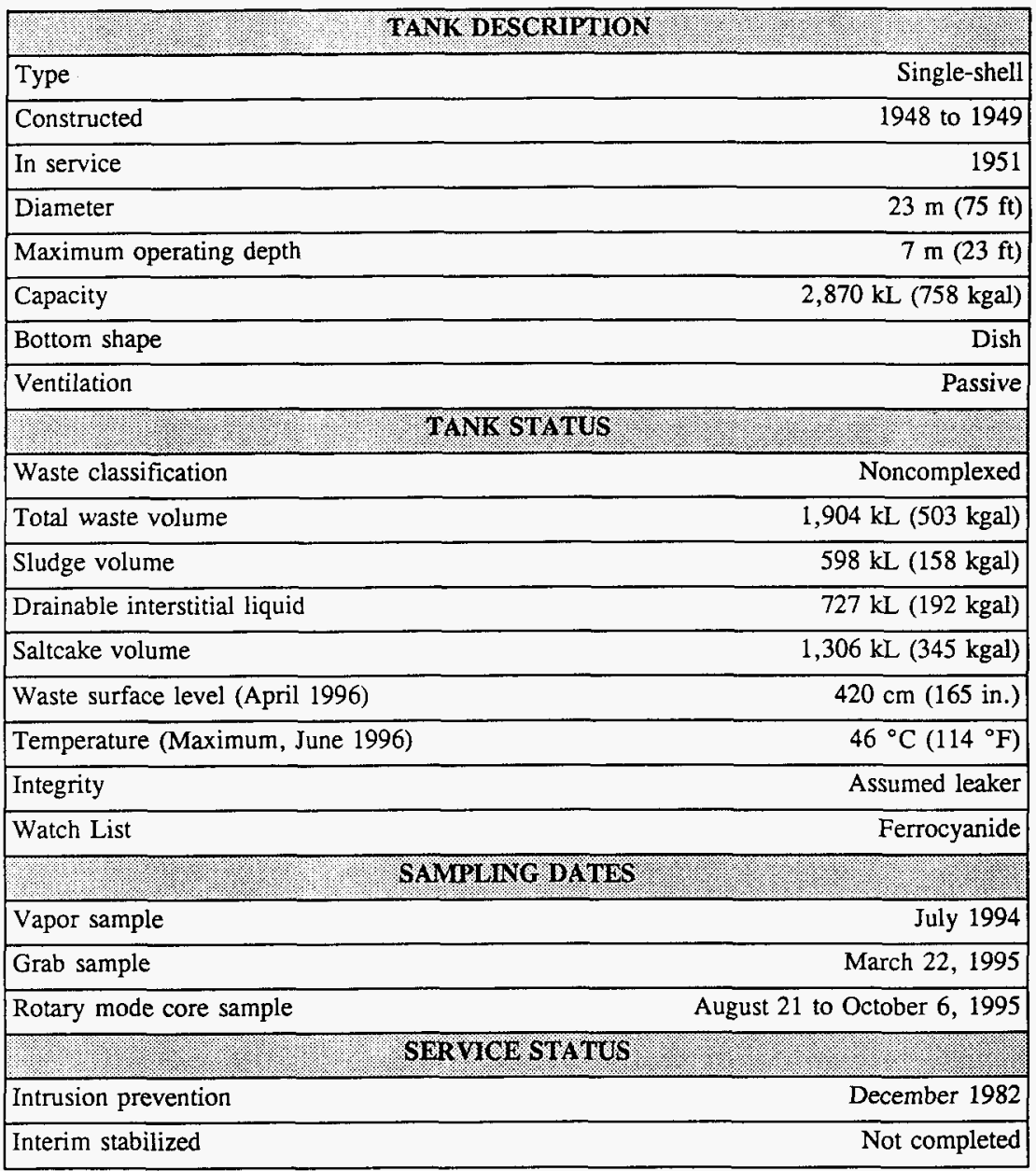


Figure ES-1. Profile of Tank 241-BY-105.
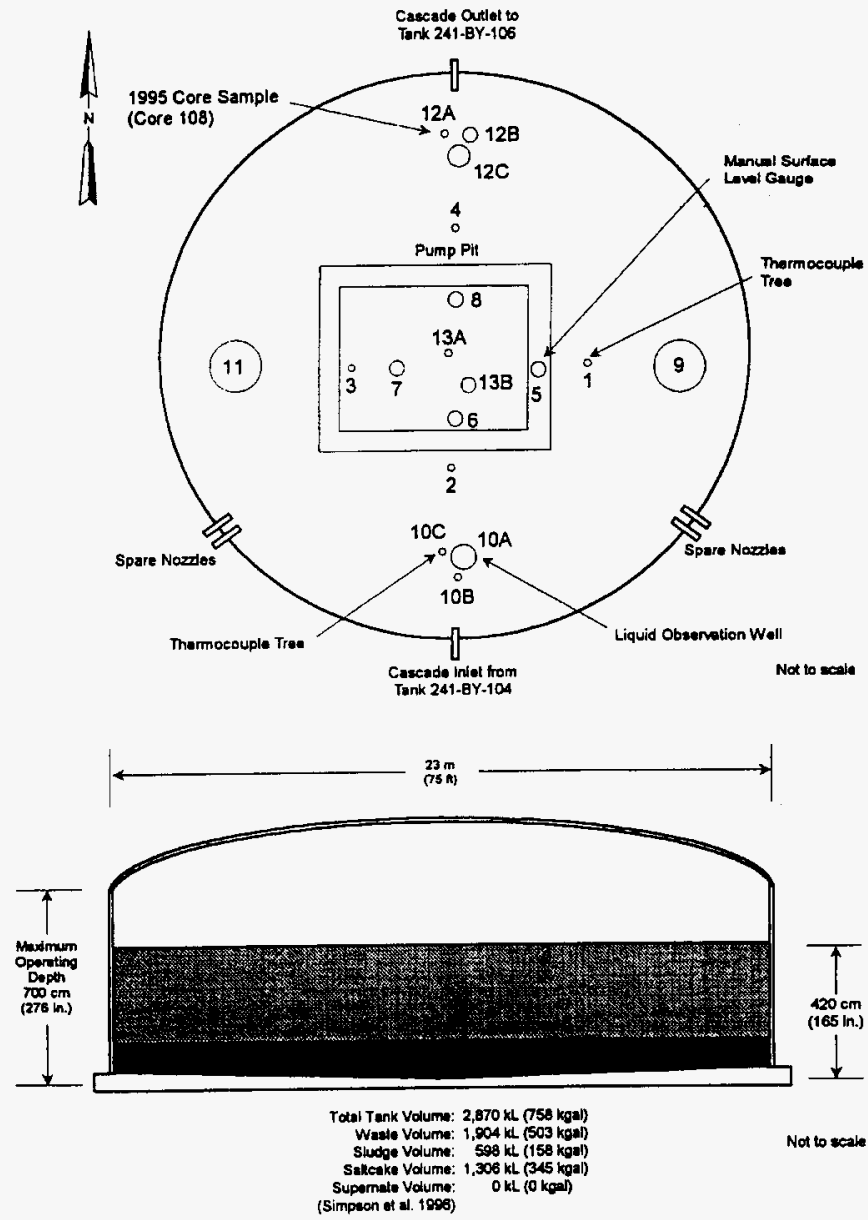
relatively favorably with drainable liquid results from the September 1995 core sampling event.

Based on the sampling and analysis plan (Sasaki 1995), two cores were to be taken and extruded and analyzed at the Westinghouse Hanford Company 222-S Laboratory in accordance with the Tank Safety Screening Data Quality Objective (Dukelow et al. 1995), the Strategy for Sampling Hanford Site Tank Wastes for Development of Disposal Technology (Kupfer et al. 1995), the Data Requirements for the Ferrocyanide Safery Issue Developed through the Data Quality Objectives Process (Meacham et al. 1994), the Test Plan for Samples From Hanford Waste Tanks 241-BY-103, BY-104, BY-105, BY-106, BY-108, BY-110, TY-103, U-105, U-107, U-108, and U-109 (Meacham 1995), Historical Model Evaluation Data Requirements (Simpson and McCain 1995), and Data Quality Objective to Support Resolution of the Organic Complexant Safety Issue (Turner et al. 1995).

During the September 1995 sampling event, core 108 was taken from tank 241-BY-105 using push and rotary core sampling methods. Only the upper portion of core 108 was sampled because the waste surface was too hard for the push core drilling method, and flammable gas restrictions were placed on all tanks in September 1995 just after starting the sampling of segment 3. The flammable gas restrictions prevented further sampling of tank 241-BY-105 using rotary core drilling.-Tank safety program personnel were consulted, and a decision was made to perform only the safety screening and total organic carbon analyses on these samples because of the limited amount of material obtained (Sasaki 1996a). 
Analyses included determinations for energetics, moisture content, total alpha activity, density, and total organic carbon (TOC). Metals and anions were analyzed to assess lithium and bromide ions so that hydrostatic intrusion could be determined. Because ion chromatography (IC) and inductively coupled plasma (ICP) were used for lithium and bromide analyses, results for the other IC and ICP analytes were also obtained. No sample composite or selected segment analyses were performed.

No sample obtained from tank 241-BY-105 had mean exothermic reactions (on a dry-weight basis) exceeding the safety screening and ferrocyanide DQOs limit of an enthalpy change of $-480 \mathrm{~J} / \mathrm{g}$ (dry weight). Although two results were substantially above the limit, subsequent triplicate analysis failed to confirm their presence. The computation of a 95 percent confidence interval on the mean for these samples (required by the safety screening DQO) indicated the highest upper limit for a liquid sample was $-1,895 \mathrm{~J} / \mathrm{g}$ from segment $1 \mathrm{AR}$ (sample S95T003418, drainable liquid).

The average water content for segment $1 \mathrm{AR}$ drainable liquid was 53.84 weight percent, and the TOC was $1,920 \mu \mathrm{g} \mathrm{C} / \mathrm{mL}$. The highest upper limit for a solid sample was $-1,053 \mathrm{~J} / \mathrm{g}$ from segment 3 (sample S99T003399, solid). The average water content was 5.7 weight percent, and the TOC was $669 \mu \mathrm{g} \mathrm{C} / \mathrm{mL}$. Mean cyanide results for these samples were low, $4.89 \mu \mathrm{g} / \mathrm{g}$ (segment $1 \mathrm{AR}$ ) and $10.7 \mu \mathrm{g} / \mathrm{g}$ (segment 3). Adiabatic calorimetry results using a reactive system screening tool showed no self-heating or gas generating response for these samples (Bechtold 1996). Other sample exotherms were below the notification limit. The 
mean total organic carbon results for all samples were $3,870 \mu \mathrm{g} \mathrm{C} / \mathrm{g}$ (dry), well below the notification limit of $30,000 \mu \mathrm{g} \mathrm{C/g}$ (dry).

The heat load in the tank produced by radioactive decay could not be determined from the sample data, but it is estimated between $2.46 \mathrm{~kW} \mathrm{(8,390} \mathrm{Btu/hr)} \mathrm{(Agnew} \mathrm{et} \mathrm{al.} \mathrm{1996)} \mathrm{and}$ $2.55 \mathrm{~kW}(8,700 \mathrm{Btu} / \mathrm{hr})$ (Kummerer 1994). Surveillance data show that the tank temperature has gradually decreased since January 1993 . On June 3,1996 , the maximum tank temperature measured was $46^{\circ} \mathrm{C}\left(114^{\circ} \mathrm{F}\right)$. The current estimated heat load and thermal history indicate that temperatures generated by tank waste are too low to initiate exothermic reactions. During core sampling, combustible gas meter readings were taken in the tank headspace as required by the safety screening DQO (Dukelow et al. 1995). The flammability level in the tank headspace for the breather filter and risers $12 \mathrm{~A}$ and $12 \mathrm{~B}$ was measured at 0 percent of the lower flammability limit (LFL).

Total alpha activity results were well below the safety screening limit of $1 \mathrm{~g} / \mathrm{L}$ of plutonium (equivalent to $31 \mu \mathrm{Ci} / \mathrm{g}$ for tank $241-\mathrm{BY}-105$ samples); the highest upper 95 percent confidence interval on the mean result was $0.06 \mu \mathrm{Ci} / \mathrm{g}$. This indicates the potential for a criticality event in the upper portion of the tank is extremely low. No samples were collected from the waste at the tank bottom.

Table ES-2 shows concentrations for the most prevalent analytes and analytes of concern based on September 1995 core sample analytical results. The tank inventory was not calculated because samples were taken from only one riser and the top three tank segments. 
Table ES-2. Major Analytes and Analytes of Concern ${ }^{1}$.

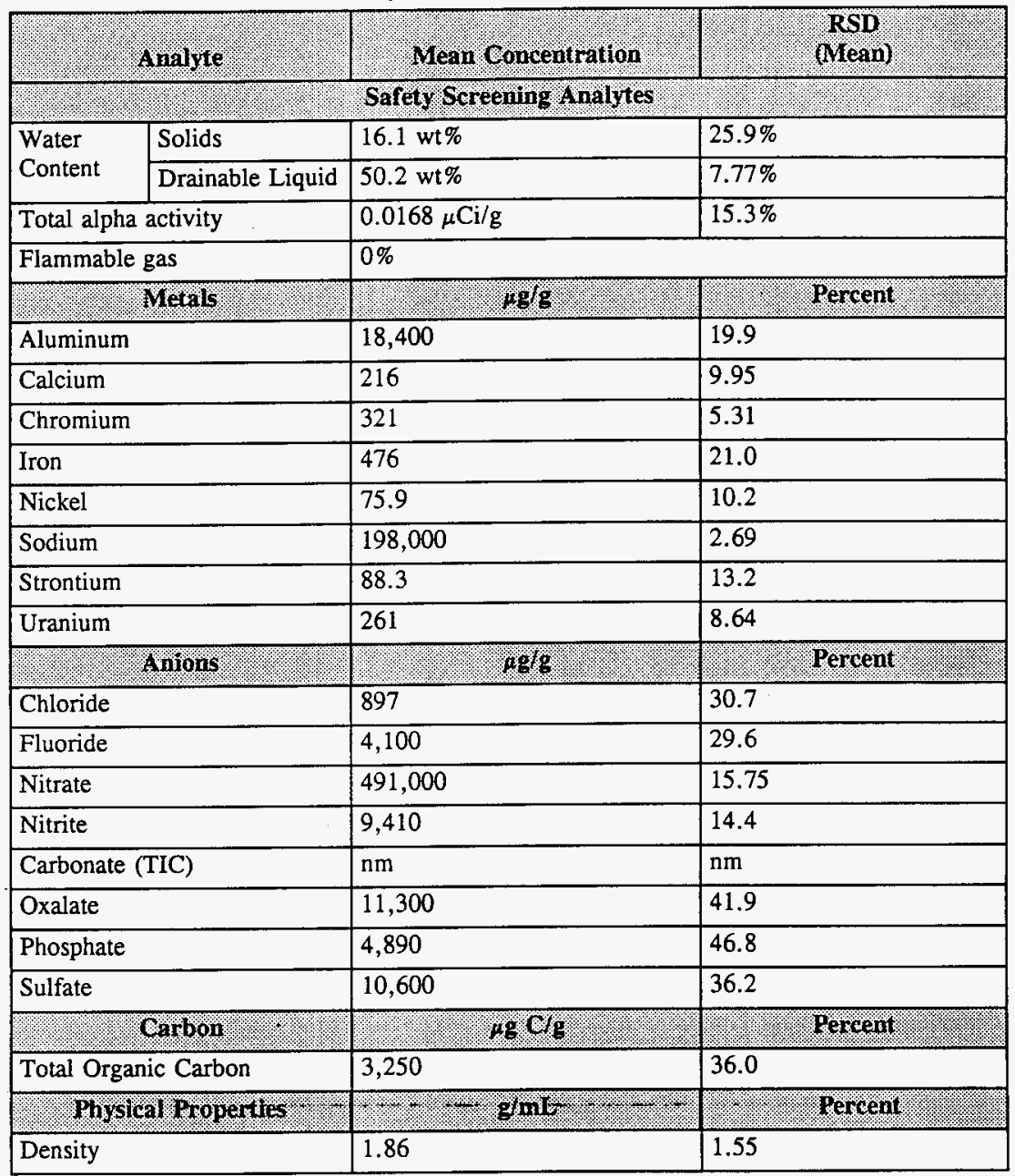

Notes:

$\mathrm{nm}=$ not measured

'Sasaki (1996). These results are limited to the upper portion of one core. 


\section{CONTENTS}

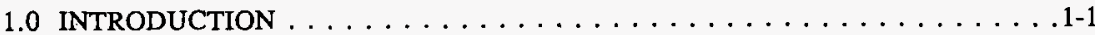

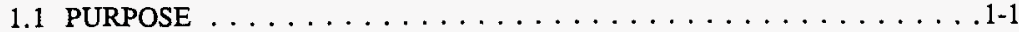

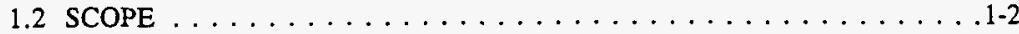

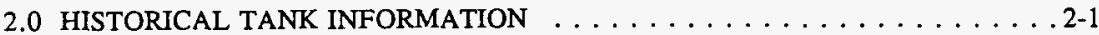

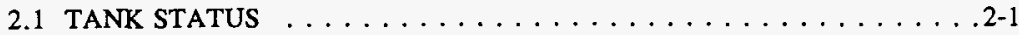

2.2 TANK DESIGN AND BACKGROUND $\ldots \ldots \ldots \ldots \ldots \ldots \ldots \ldots .2-2$

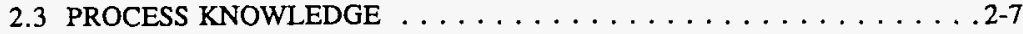

2.3.1 Waste Transfer History . . . . . . . . . . . . . 2-7

2.3.2 Historical Estimation of Tank Contents . . . . . . . . 2-8

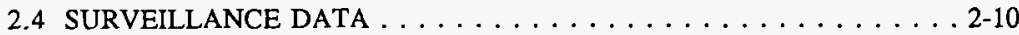

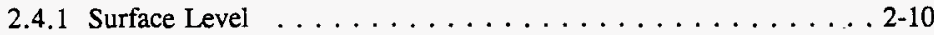

2.4 .2 Dry Wells . . . . . . . . . . . . . . . . 2-14

2.4.3 Internal Tank Temperatures . . . . . . . . . . . 2-14

2.4.4 Tank 241-BY-105 Photographs . . . . . . . . . . . . 2-14

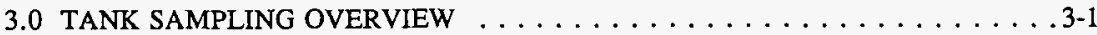

3.1 DESCRIPTION OF THE 1995 CORE SAMPLING EVENT $\ldots \ldots \ldots \ldots$. . . .

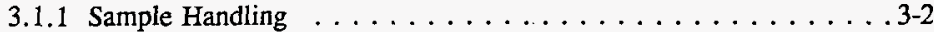

3.1.2 Sample Analysis . . . . . . . . . . . . . 3-3

3.2 DESCRIPTION OF THE 1995 GRAB SAMPLE EVENT . . . . . . 3-3

3.31994 VAPOR ANALYSIS DESCRIPTION $\ldots \ldots \ldots \ldots \ldots \ldots \ldots \ldots .7$

3.4 HISTORICAL SAMPLES $\ldots \ldots \ldots \ldots \ldots \ldots \ldots \ldots \ldots \ldots \ldots$

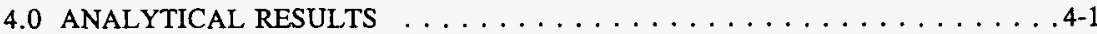

4.1 DATA PRESENTATION . . . . . . . . . . . . . . 4-1

4.2 CHEMICAL DATA SUMMARY . . . . . . . . . . . 4-2

4.2.1 Inductively Coupled Plasma and Ion Chromatography Analyses . . . 4-2

4.2 .2 Total Alpha . . . . . . . . . . . . . . . . . 4-2

4.2.3 Total Organic Carbon . . . . . . . . . . . . . 4-5

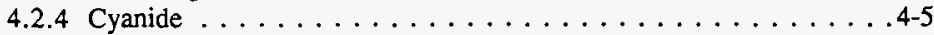

4.2 .5 Separable Organic Layer $\ldots \ldots \ldots \ldots \ldots \ldots \ldots \ldots \ldots \ldots$

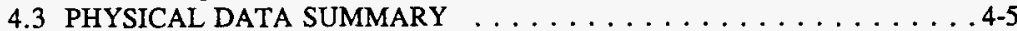

4.3.1 Thermogravimetric Analysis . . . . . . . . . 4-5

4.3.2 Differential Scanning Calorimetry $\ldots \ldots \ldots \ldots \ldots \ldots \ldots$ 4-6

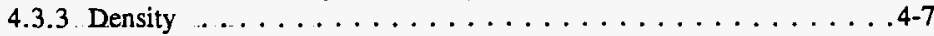

4.4 ANALYSIS FOR HYDROSTATIC HEAD FLUID CONTAMINATION $\ldots .48$

4.5 HEADSPACE VAPOR SAMPLING $\ldots \ldots \ldots \ldots \ldots \ldots \ldots \ldots .8$ 


\section{CONTENTS (Continued)}

5.0 INTERPRETATION OF CHARACTERIZATION RESULTS . . . . . . . 5-1

5.1 ASSESSMENT OF SAMPLING AND ANALYTICAL RESULTS $\ldots \ldots$ 5-1

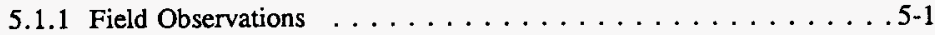

5.1 .2 Quality Control Assessment ............... 5-1

5.1.3 Data Consistency Checks . . . . . . . . . . . . . . 5-2

5.2 COMPARISON OF 1995 CORE SAMPLE and GRAB SAMPLE

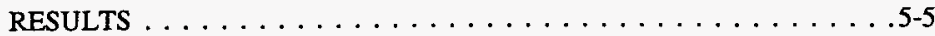

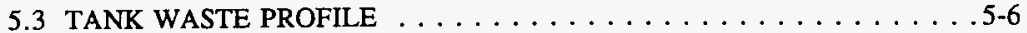

5.4 COMPARISON OF ANALYTICAL AND TRANSFER DATA $\ldots \ldots \ldots 5-7$

5.5 SAFETY EVALUATION $\ldots \ldots \ldots \ldots \ldots \ldots \ldots \ldots \ldots \ldots \ldots$

6.0 CONCLUSIONS AND RECOMMENDATIONS $\ldots \ldots \ldots \ldots \ldots \ldots \ldots$ 6-1

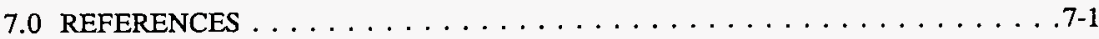

\section{APPENDICES:}

A ANALYTICAL RESULTS FROM 1995 CORE SAMPLING . . . . . . . A A-1

B RESULTS OF HYDROSTATIC HEAD FLUID CONTAMINATION CHECK . . B-1

C MARCH 1995 GRAB SAMPLING RESULTS $\ldots \ldots \ldots \ldots \ldots \ldots$ C-1 


\section{LIST OF FIGURES}

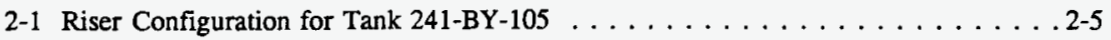

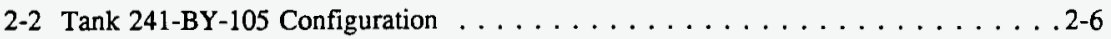

2-3 Tank Layer Model for Tank 241-BY-105 . . . . . . . . . . . . . . . 2-9

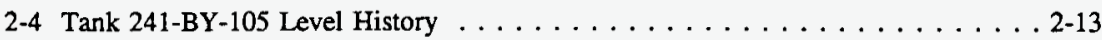

2-5 Tank 24I-BY-105 Weekly High Temperature Plot $\ldots \ldots \ldots \ldots$ 2-15 . . . . .

\section{LIST OF TABLES}

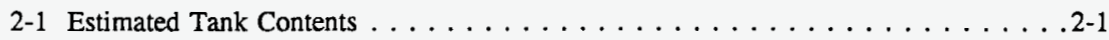

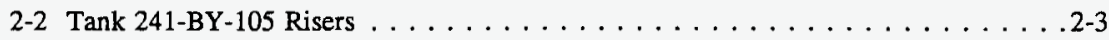

2-3 Summary of Tank 241-BY-105 Waste Transfer History $\ldots \ldots \ldots \ldots$. . . . . . . .

2-4 Tank 241-BY-105 Inventory Estimate $\ldots \ldots \ldots \ldots \ldots \ldots \ldots \ldots \ldots \ldots \ldots \ldots .11$

3-1 Integrated Requirements for Tank $241-\mathrm{BY}-105 \ldots \ldots \ldots \ldots$. . . . . . . . . . .

3-2 Core 108 Sample Description . . . . . . . . . . . . . . . 3-4

3-3 Analytical Procedures $\ldots \ldots \ldots \ldots \ldots \ldots \ldots \ldots \ldots \ldots \ldots . \ldots \ldots$

4-1 Analytical Data Tables $\ldots \ldots \ldots \ldots \ldots \ldots \ldots \ldots \ldots \ldots \ldots \ldots \ldots$ 4-1

4-2 Chemical Data Summary for Tank 241-BY-105 Saltcake . . . . . . . . . 4-3

4-3 Selected Vapor Space Characterization Data . . . . . . . . . . . . . . 4-9

4-4 Vapor Flammability Results from 1994 Vapor Sampling and Analysis Event . . . . 4-9

5-1 Comparison of Phosphate/Phosphorous and Sulfate/Sulfur Concentrations by Different Methods . . . . . . . . . . . . 5-3

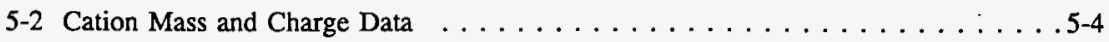




\section{LIST OF TABLES (Continued)}

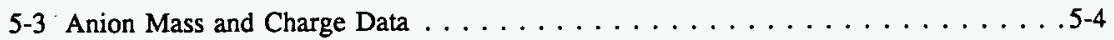

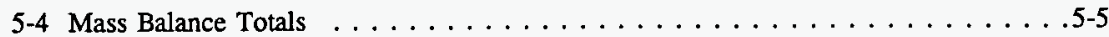

5-5 Comparison of 1995 core sample and grab sample results . . . . . . . . 5-6

5-6 Comparison of BY Saltcake Fingerprint Analytes with Analytical Results . . . . . 5-7

5-7 Comparison of DSC Analytical Results Exceeding the Threshold Limit with TOC and Cyanide Results . . . . . . . . . . . . . . . . 5-9 


\section{LIST OF TERMS}

\begin{tabular}{|c|c|}
\hline ANOVA & analysis of variance \\
\hline Btu & British thermal units \\
\hline C & carbon \\
\hline $\mathrm{Ci}$ & curies \\
\hline $\mathrm{cm}$ & centimeter \\
\hline $\mathrm{cm}^{3}$ & cubic centimeters \\
\hline cl & counts per second \\
\hline DL & drainable liquid \\
\hline DQO & data quality objective \\
\hline $\mathrm{DSC}$ & differential scanning calorimetry \\
\hline $\mathrm{ft}$ & feet \\
\hline g & gram \\
\hline HTCE & Historical Tank Content Estimate \\
\hline IC & ion chromatography \\
\hline ICP/AES & inductively coupled plasma/atomic emission spectrometry \\
\hline in. & inches \\
\hline ITS & in-tank solidification \\
\hline J & joule \\
\hline kg & kilogram \\
\hline kgal & kilogallon \\
\hline kL & kiloliter \\
\hline $\mathrm{kW}$ & kilowatt \\
\hline $\mathrm{L}$ & liter \\
\hline LFL & lower flammability limit \\
\hline $\mathrm{m}$ & meter \\
\hline $\mathbf{M}$ & molar \\
\hline $\mathrm{mg}$ & milligram \\
\hline $\mathrm{mL}$ & milliliter \\
\hline $\mathrm{mR} / \mathrm{hr}$ & milliroentgen per hour \\
\hline $\mathbf{N}$ & Newton \\
\hline PFeCN1 & type 1 in-plant ferrocyanide \\
\hline PFeCN2 & type 2 in-plant ferrocyanide \\
\hline PNNL & Pacific Northwest National Laboratory \\
\hline ppm & parts per million \\
\hline ppmv & parts per million by volume \\
\hline RPD & relative percent difference \\
\hline $\mathrm{RSD}$ & relative standard deviation \\
\hline SAP & sampling and analysis plan \\
\hline TIC & total inorganic carbon \\
\hline TGA & thermogravimetric analysis \\
\hline TLM & Tank Layer Model \\
\hline TOC & total organic carbon \\
\hline
\end{tabular}


WHC-SD-WM-ER-598 Rev. 0

\section{LIST OF TERMS (Continued)}

$\begin{array}{ll}\text { W } & \text { watts } \\ \text { WSTRS } & \text { Waste Status and Transaction Record Summary } \\ \text { wt\% } & \text { weight percent } \\ { }^{\circ} \mathrm{C} & \text { degrees Celsius } \\ { }^{\circ} \mathrm{F} & \text { degrees Fahrenheit } \\ \mu & \text { micro } \\ \mu \mathrm{Ci} & \text { microcurie } \\ \mu \mathrm{g} & \text { microgram } \\ \mu \mathrm{eq} & \text { microequivalent }\end{array}$




\subsection{INTRODUCTION}

This tank characterization report summarizes the information on the historical uses, current status, and sampling and analysis results of waste stored in single-shell tank 241-BY-105. The tank waste was push and rotary core sampled between August and October 1995 to satisfy the requirements of the following documents: the Tank Safety Screening Data Quality Objective (Dukelow et al. 1995), the Data Requirements for the Ferrocyanide Safety Issue Developed through the Data Quality Objectives Process (Meacham et al. 1994), the Data Quality Objective to Support Resolution of the Organic Complexant Safety 7ssue (Turner et al. 1995), Test Plan for Samples From Hanford Waste Tanks 241-BY-103, BY-104, BY-105, $B Y-108, B Y-110, T Y-103, U-105, U-107, U-108$, and $U-109$ (Meacham 1995), the Historical Model Evaluation Data Requirements (Simpson and McCain 1995), and the Strategy for Sampling Hanford Site Tank Wastes for Development of Disposal Technology (Kupfer et al. 1995). Grab sampling was completed in March 1995 to satisfy the requirements of Data Quality and Objectives for the Waste Compatibility Program (Fowler 1995). A previous vapor sample event was taken in May and July 1994 to address sampling operations and industrial safety and health concerns (Huckaby and Bratzel 1995). This report supports the requirements of the Hanford Federal Facility Agreement and Consent Order, Milestone M-44-09 (Ecology et al. 1996) and Ferrocyanide Safety Program, Milestone T22-96-020 (WHC 1995b).

Tank 241-BY-105 has been removed from service, and intrusion prevention has been completed. Interim stabilization is not completed yet, but it is unlikely that waste removals or additions will occur until pretreatment and retrieval activities commence. Sampling and analysis of this tank is not complete. The concentration estimates reported in this document reflect the current composition of the saltcake waste based on available data.

Tank 241-BY-105 is on the Ferrocyanide Watch List and is an assumed leaker. In addition, it potentially contains organic complexants (WHC 1995a).

\subsection{PURPOSE}

This report summarizes information about the use and contents of tank 241-BY-105. When possible, this information will be used to assess issues associated with safety, operations, environmental, and process activities. 


\subsection{SCOPE}

In May and July 1994, vapor samples were taken from the headspace of tank 241-BY-105 to address sampling operations and industrial safety and health concerns. On March 22, 1995, two grab samples were taken from riser 5 for compatibility analyses. Between August and October 1995, push and rotary mode samples were taken from the upper portion of the waste. Only the upper portion of one core was obtained because of difficulties in using the push core drilling method. Poor sample retrieval and flammable gas restrictions placed on all tanks during the tank 241-BY-105 sampling event prevented further attempts using rotary core drilling. As a result of these constraints, tank safety program personnel were consulted, and a decision was made to perform only the safety screening and total organic carbon analysis on these partial samples (Sasaki 1996a). Consequently, the data quality objectives (DQOs) for this tank were not fully met.

A full vapor characterization of the tank headspace gases was done prior to the sampling event. Primary analyses performed on the partial core samples obtained included the following: differential scanning calorimetry (DSC) to evaluate fuel level and energetics, thermogravimetric analysis (TGA) to determine moisture content, total alpha activity analysis and density to evaluate criticality potential, persulfate oxidation to determine the TOC concentration, and ICP metals and IC anions to assess potential intrusion of wash solution (lithium bromide traced water). 


\subsection{HISTORICAL TANK INFORMATION}

This section describes tank 241-BY-105 based on historical information. It details the current condition of the tank and provides information on the tank design and transfer history and the process sources that contributed to the tank waste, including an estimate of the current contents based on the process history. It includes information that may be related to tank safety issues, such as potentially hazardous tank contents or off-normal operating temperatures. This section also summarizes available surveillance data for the tank. Solid and liquid level data are used to determine tank integrity (leaks) and to provide clues to internal activity in the solid layers of the tank. Temperature data are provided to evaluate the heat generating characteristics of the waste.

\subsection{TANK STATUS}

As of February 29, 1996, tank 241-BY-105 contained an estimated 1,904 kL (503 kgal) of waste classified as noncomplexed (Hanlon 1996). Liquid waste volume is estimated by photographic evaluation. Solid waste volume is estimated using a manual tape and by photographic evaluation. The total solids volume was last updated on April 28, 1982. The amounts of existing waste phases in the tank are shown in Table 2-1.

Table 2-1. Estimated Tank Contents.

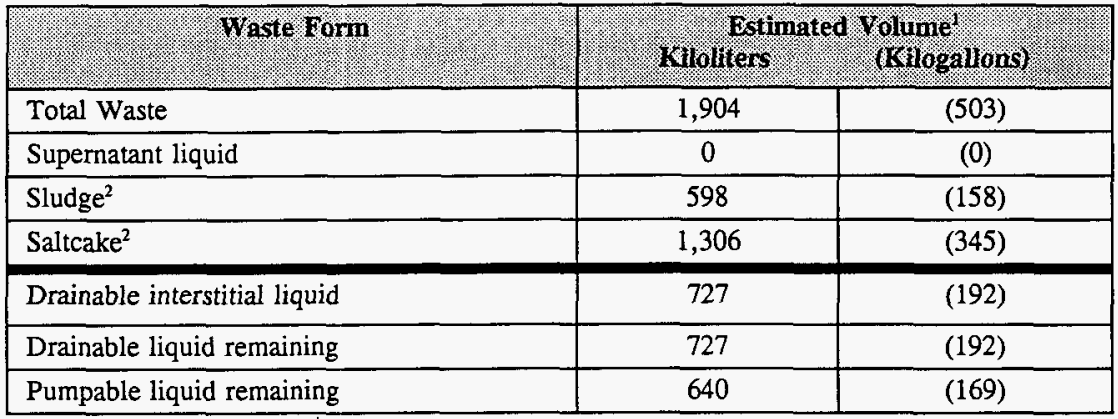

Notes:

'For definitions.and calculation methods, refer to.Hanlon (1996).

'For data used to make these determinations, see Section 2.4.1 
Tank 241-BY-105 is out of service as are all single-shell tanks. The tank was declared an assumed leaker in 1984 with an estimated leak volume of $30 \mathrm{~kL}$ (8 kgal). The tank was partially isolated in December 1982, but interim stabilization has not been completed. The tank is on the Ferrocyanide Watch List. The tank is passively ventilated. All monitoring systems were in compliance with documented standards as of February 29, 1996 (Hanlon 1996).

\subsection{TANK DESIGN AND BACKGROUND}

The 241-BY Tank Farm was constructed between 1948 and 1949 in the 200 East Area of the Hanford Site. The 241-BY Tank Farm contains 12 type II 100-series tanks. The tanks have a $2,870 \mathrm{~kL}$ ( $758 \mathrm{kgal})$ capacity, $23 \mathrm{~m}$ ( $75 \mathrm{ft}$ ) diameter, and a $7 \mathrm{~m}(23 \mathrm{ft}$ ) operating depth (Leach and Stahl 1993). Built as one of the second generation tank farms, the 241-BY Tank Farm was designed for nonboiling waste with a maximum fluid temperature of $104{ }^{\circ} \mathrm{C}$ $\left(220^{\circ} \mathrm{F}\right)$. This tank is part of a six tank cascade that includes tanks 241-BX-104, 241BX-105, 241-BX-106, BY-104, 241-BY-105, and BY-106. Tank 241-BX-106 cascades across tank farms to tank 241-BY-104. However, anecdotal evidence indicates that the cascade from the BX farm to the BY farm did not function well. As a result, the BX Farm and BY Farm cascades often operated separately. In the BY Farm a $7.5 \mathrm{~cm}$ (3 in.) cascade overflow line connects tank $241-\mathrm{BY}-105$ as second in a three-tank cascade series that includes tanks $241-\mathrm{BY}-104$ and 241-BY-106. The cascade overflow height is approximately $6.9 \mathrm{~m}$ $(22.7 \mathrm{ft})$ from the tank bottom and $0.6 \mathrm{~m}(2 \mathrm{ft})$ below the top of the steel liner.

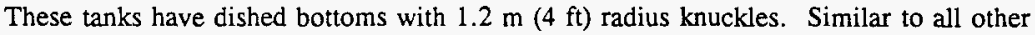
single-shell tank farms, the tanks in the BY Tank Farm are built with primary mild steel liners and concrete domes with various risers. The tanks are set on reinforced concrete foundations. Lead flashing was used to protect the joint where the steel liner meets the concrete dome. The tanks were waterproofed on the sides and top with tar and welded-wire reinforced gunite. Each tank is covered with approximately $2.6 \mathrm{~m}(8 \mathrm{ft})$ of overburden.

Tank 241-BY-105 has 21 risers including three "caissons" that are labeled risers. These risers range in size from $10 \mathrm{~cm}$ (4 in.) to $1.1 \mathrm{~m} \mathrm{(42} \mathrm{in.)} \mathrm{in} \mathrm{diameter.} \mathrm{Table} 2-2$ shows riser and nozzle numbers, sizes and descriptions. Figure 2-1 shows the riser configuration. The tank has three air-lift circulators. Figure 2-2 is a tank cross section that shows the approximate waste level and a schematic of the tank equipment. 
Table 2-2. Tank 241-BY-105 Risers. ${ }^{1,2,3.4}$ (2 sheets)

\begin{tabular}{|c|c|c|}
\hline Nimber & Diameler. & Description and Comments. \\
\hline 1 & 4 & Thermocouple tree, B-221 \\
\hline 2 & 4 & Covered with concrete, below grade \\
\hline 3 & 4 & Drain \\
\hline 4 & 4 & $\begin{array}{l}\text { Blind flange (breather filter [dog leg riser] ECN-617142, } \\
\text { November } 14,1993 \text { ) }\end{array}$ \\
\hline 5 & 12 & $\begin{array}{l}\text { Observation port/B-221 (liquid level reel on } 4 \text { spool CEO-39569, } \\
\text { July } 15,1987 \text { ) }\end{array}$ \\
\hline 6 & 12 & Covered with concrete \\
\hline 7 & 12 & Saltwell pump (observation port CEO-39569, July 15, 1987) \\
\hline 8 & 12 & Covered with concrete \\
\hline 9 & 42 & Sluice pit \\
\hline 10 & 42 & Caisson with cover plate \\
\hline $10 \mathrm{~A}$ & 4 & Liquid observation well \\
\hline $10 \mathrm{~B}$ & 18 & Air duct \\
\hline $10 \mathrm{C}$ & 14 & Thermocouple tree \\
\hline 11 & 42 & Sluice pit, weather covered \\
\hline 12 & 42 & Caisson with cover plate \\
\hline $12 \mathrm{~A}$ & 4 & $\begin{array}{l}\text { Breather filter (vapor assembly/breather offset ECN-189223L March } \\
10,1994 \text { ) (spare ECN-617142 November 14, 1993) }\end{array}$ \\
\hline $12 \mathrm{~B}$ & 18 & Air duct \\
\hline $12 \mathrm{C}$ & 14 & Air lift circulator, below grade \\
\hline 13 & 42 & Caisson cover plate \\
\hline $13 \mathrm{~A}$ & 4 & Observation port (not used CEO-39569 July 15, 1987) \\
\hline $13 B$ & 12 & Air circulator saltwell riser CEO-39569 July 15, 1987) \\
\hline
\end{tabular}


WHC-SD-WM-ER-598 Rev. 0

Table 2-2. Tank 241-BY-105 Risers. 1. 2. 3.4 (2 sheets)

\begin{tabular}{|c|c|l|l|}
\hline $\begin{array}{c}\text { Nozzle } \\
\text { Number }\end{array}$ & $\begin{array}{c}\text { Diameter } \\
\text { In. }\end{array}$ & \multicolumn{1}{|c|}{ Description and Conments } \\
\hline N1 & 3 & Spare inlet, capped \\
\hline N2 & 3 & Spare inlet, capped \\
\hline N3 & 3 & Spare inlet, capped \\
\hline N4 & 3 & Spare inlet, capped \\
\hline N5 & 3 & Overflow inlet \\
\hline N6 & 3 & Overflow outlet \\
\hline
\end{tabular}

Notes:

$\mathrm{CEO}=$ change engineering order

$E C N=$ engineering change notice

'Alstad (1993)

${ }^{2}$ Tran (1993)

${ }^{3}$ WHC (1988)

${ }^{4}$ WHC (1976) 
WHC-SD-WM-ER-598 Rev. 0

Figure 2-1. Riser Configuration for Tank 241-BY-105.

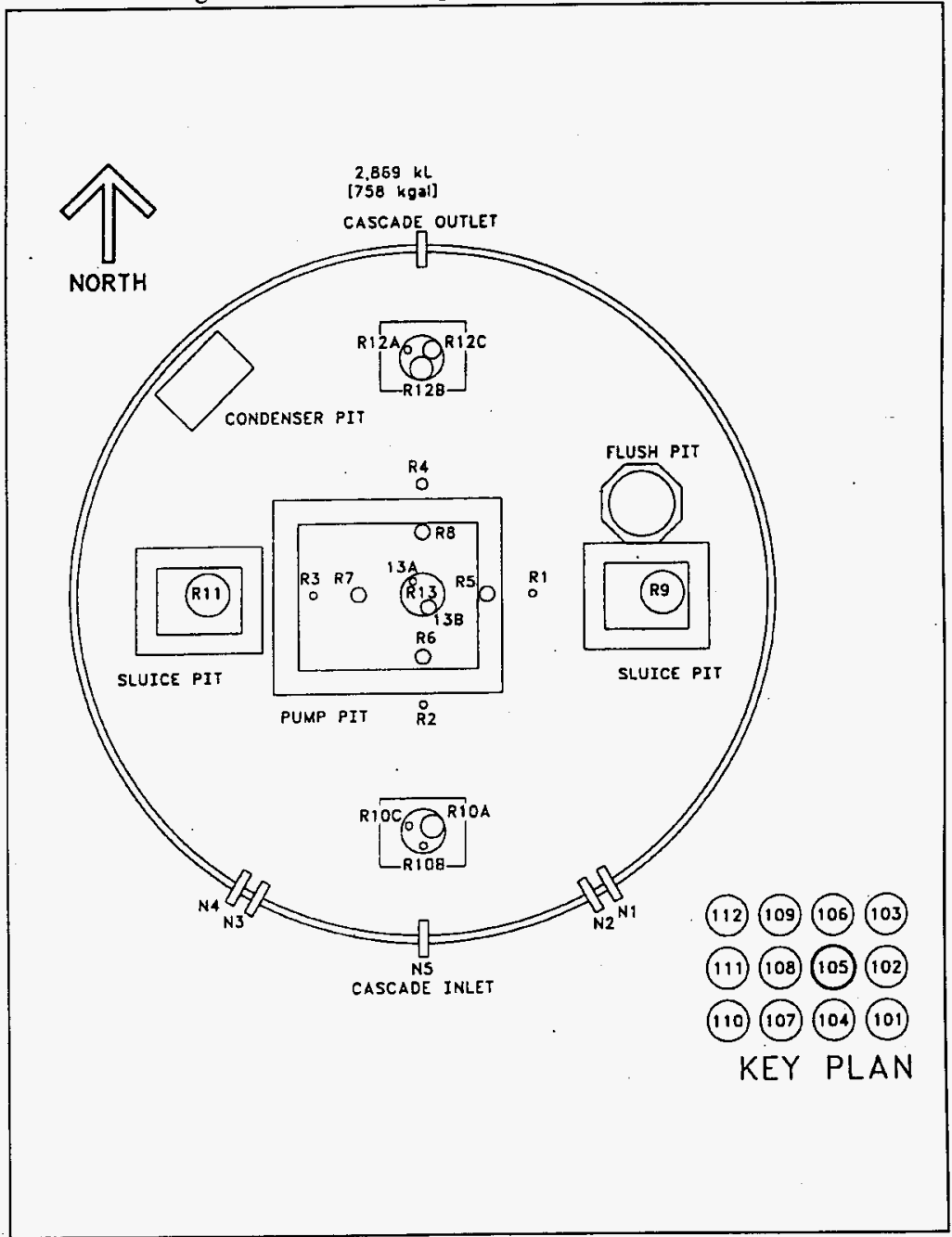


Figure 2-2. Tank 241-BY-105 Configuration.

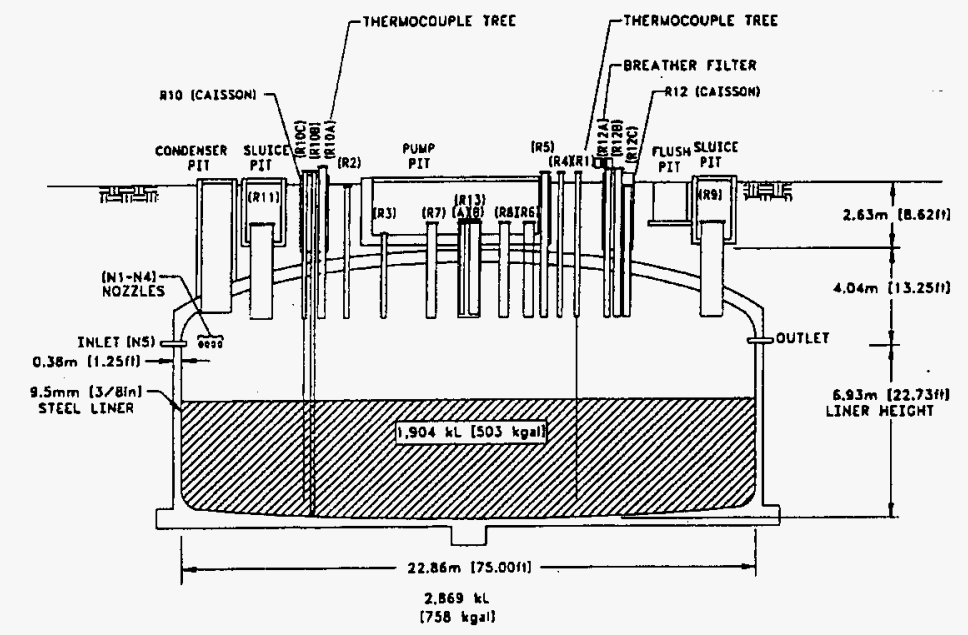




\subsection{PROCESS KNOWLEDGE}

This section describes the transfer history of tank 241-BY-105 and the process wastes that made up the transfers. This is followed by an estimate of current tank contents based on transfer history. Table 2-3 summarizes the waste transfers for tank 241-BY-105.

\subsubsection{Waste Transfer History}

In 1951, metal waste cascaded to tank 241-BY-105 from tank 241-BY-104. Tank 241-BY-105 was sluiced during the third quarter of 1954, and a small heel of metal waste was assumed to remain. From 1954 to 1956, tank 241-BY-105 was a sludge collection tank and received in-plant ferrocyanide waste from tanks 241-BY-106, 241-BY-107, 241-BY-108 and 241-BY-110. However in 1956, the ferrocyanide scavenged waste had completely settled and the supernatant was transferred to $100-\mathrm{B}$ and $100-\mathrm{C}$ area cribs. Flush water from miscellaneous sources was added to tank 241-BY-105 during 1957.

PUREX cladding waste was received by tank 241-BY-105 in 1961. Additional cladding waste originating from tanks 241-C-107, 241-C-108, and 241-BY-101 was received in 1966. In November 1966, the tank received 63 tons of Portland cement as part of a tank solidification effort (Hodgson 1995). In 1967, tank 241-BY-105 was designated as an in-tank solidification (ITS) bottoms receiver. From 1968 until 1974, tank 241-BY-105 received ITS waste, ITS evaporator bottoms waste and evaporator bottoms waste from tanks 241-BY-102, 241-BY-109, or 241-BY-112. During 1971 and 1974, flush water from miscellaneous sources was added to tank 241-BY-105. The Waste Status and Transaction Record Summary (WSTRS) for the Northeast Quadrant (Agnew et al. 1995b) has recorded the addition of BY saltcake waste to tank 241-BY-105 in 1976. It is believed this addition was a further concentration of the ITS waste. Anderson (1990) reported that 63 tons of Portland cement were added in 1977. This is probably incorrect because Anderson also reported the 1966 transfer of cement to the tank. Two cement additions are not consistent with analytical results, and no reference could be found to support the 1977 addition. Approximately 1,904 $\mathrm{kL}(503 \mathrm{kgal})$ of waste were left in tank 241-BY-105 after the final transfer from it in 1982. 
Table 2-3. Summary of Tank 241-BY-105 Waste Transfer History ${ }^{1,2}$.

\begin{tabular}{|c|c|c|c|c|}
\hline \multirow{2}{*}{ Transfer } & \multirow[b]{2}{*}{ Waste Iype Received } & \multirow[b]{2}{*}{ Tinie } & \multicolumn{2}{|c|}{ Waste Yolume } \\
\hline & & & $\mathrm{du}$ & kgal. \\
\hline 241-BY-104 & Metal waste & 1951 & 2,078 & (549) \\
\hline 241-BY-107 & $\begin{array}{l}\text { In-plant (U Plant) ferrocyanide } \\
\text { scavenged waste }\end{array}$ & 1954 to 1956 & 1,620 & $(428)$ \\
\hline $241-B Y-110$ & $\begin{array}{l}\text { In-plant (U Plant) ferrocyanide } \\
\text { scavenged waste }\end{array}$ & 1954 to 1956 & 1,321 & (349) \\
\hline 241-BY-108 & $\begin{array}{l}\text { In-plant (U Plant) ferrocyanide } \\
\text { scavenged waste }\end{array}$ & 1955 to 1956 & 636 & (168) \\
\hline 241-BY-106 & $\begin{array}{l}\text { In-plant (U Plant) ferrocyanide } \\
\text { scavenged waste }\end{array}$ & 1956 & 79 & (21) \\
\hline $241-C-108$ & Cladding waste PUREX & 1961 & 344 & (91) \\
\hline $241-C-107$ & Cladding waste PUREX & 1961 & 727 & (192) \\
\hline 241-BY-101 & Cladding waste & 1966 & 450 & (119) \\
\hline $241-\mathrm{BY}-102$ & $\begin{array}{l}\text { In-tank solidification } \\
\text { evaporator bottoms waste }\end{array}$ & 1968 to 1971 & 11,110 & $(2,935)$ \\
\hline 241-BY-109 & $\begin{array}{l}\text { Evaporator bottoms waste/ } \\
\text { in-tank solidification } \\
\text { evaporator bottoms waste }\end{array}$ & 1970 to 1974 & 2,797 & (739) \\
\hline $241-B Y-112$ & In-tank solidification waste & 1971 to 1974 & 386 & (102) \\
\hline
\end{tabular}

Notes:

'Waste volumes and types are best estimates based on historical data.

${ }^{2}$ Agnew et al. (1995b)

\subsubsection{Historical Estimation of Tank Contents}

The historical data used to estimate the contents of tank 241-BY-105 are from the Waste Status and Transaction Record-Summary for the Northeast Quadrant (Agnew et al. 1995b), the Hanford Tank Chemical and Radionuclide Inventories: HDW Model Rev. 3 (Agnew et al. 1996), the Tank Layer Model for Northeast, Southwest, and Northwest Quadrants (Agnew et al. 1995a), and the tank inventory composition estimates to be placed in the updates of the Historical Tank Content Estimate (HTCE) for the Northeast Quadrant of the Hanford 200 East Area (Brevick et al. 1995). The Waste Status and Transaction Record Summary (WSTRS) is a compilation of available waste transfer and volume status data. The Hanford 
Defined Waste (HDW) provides the assumed typical compositions for Hanford waste types. In most cases, the available data are incomplete thereby reducing the reliability of the transfer data and the derived modeling results. The Tank Layer Model (TLM), uses the WSTRS data to model the waste deposition processes and from the HDW (which may introduce more error), to generate an estimate of the tank contents. Because of the possibility of introducing errors, these model predictions can only be considered an estimate that requires further evaluation using analytical data.

Agnew et al. (1996) estimates that tank 241-BY-105 contains $61 \mathrm{~kL}$ (16 kgal) of type 2 metal waste $(\mathrm{MW} 2)$ from the bismuth phosphate $\left(\mathrm{BiPO}_{4}\right)$ process, $538 \mathrm{~kL}(142 \mathrm{kgal})$ of type 2 in-plant ferrocyanide scavenged waste (PFeCN2), 1,276 kL (337 kgal) of BY saltcake waste (BYSLTCK), and $30 \mathrm{~kL}$ ( $8 \mathrm{kgal}$ ) of cement. Tank 241-BY-105 contains the following waste layers from the bottom to the top: MW2, PFeCN2, BYSLTCK, and a top layer of cement. Figure 2-3 is a graphical representation of the estimated waste types and volumes for the tank layers. Table 2-4 shows an estimate of the expected waste types and quantities in the tank.

Figure 2-3. Tank Layer Model for Tank 241-BY-105.

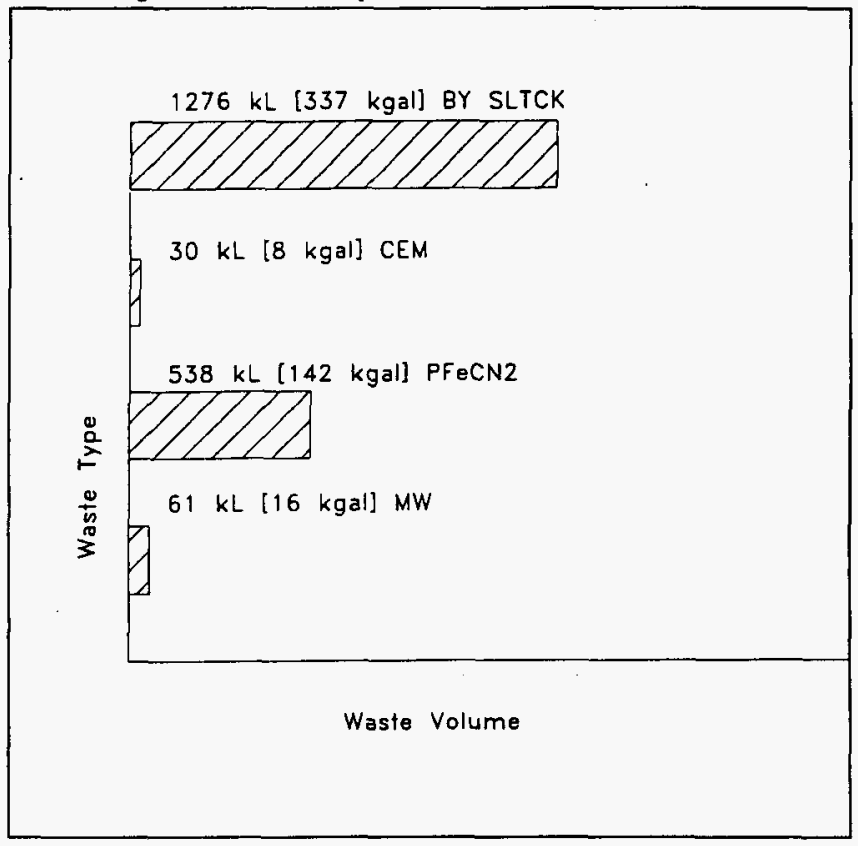




\subsection{SURVEHLANCE DATA}

Tank 241-BY-105 surveillance includes surface level measurements (liquid and solid) and temperature monitoring inside the tank (waste and headspace). The data provide the basis for determining tank integrity.

Liquid level measurements may indicate a tank leak. Solid surface level measurements may indicate physical changes and the consistency of solid layers in a tank. Drywells around the perimeter of the tank may show increased radioactivity because of a leak to the soil.

\subsubsection{Surface Level}

The tank 241-BY-105 waste surface level is monitored quarterly with a manual tape through riser 5 . The liquid waste volume is determined by photographic evaluation and the solid waste by a manual tape surface level gauge and photographic evaluation. The maximum allowable increase from the $4.62 \mathrm{~m}(15.2 \mathrm{ft})$ baseline is $5 \mathrm{~cm}(2 \mathrm{in}$.). The criterion for decrease does not apply to this tank. Tank $241-\mathrm{BY}-105$ has a liquid observation well located in riser $10 \mathrm{~A}$. To determine interstitial liquid levels, the tank is monitored weekly with a neutron probe. It is also monitored on request with a gamma probe. On April 4, 1996, the waste surface level reading was $4.2 \mathrm{~m}(13.9 \mathrm{ft})$. Figure $2-4$ shows the tank volume history based on Hanlon (1966) and Brevick et al. (1995). Swaney (1993) identified discrepancies between the waste surface level measurement and tank volumes reported in Hanlon (1996) and stated that the Hanlon report cannot be updated until new in-tank photographs are taken.

The volumes of saltcake and sludge presently documented in Hanlon (1966) do not agree with historical records or gamma and neutron scans of waste through the salt well. The transfer records of Agnew et al. (1995b) indicated that substantial heels of ferrocyanide waste were transferred to this tank, the sludge was allowed to settle, and supernatant was subsequently disposed to the $100-\mathrm{B}$ and $100-\mathrm{C}$ areas. Agnew et al. specifies a retained sludge heel of $598 \mathrm{~kL}$ (158 kgals $[61 \mathrm{~kL}$ metal waste and $539 \mathrm{~kL}$ in-plant-2 ferrocyanide waste]). Although Hodgson (1995) indicated that ferrocyanide sludge may have been removed from the tank, no tank sluicing was reported between 1965 and 1970 (Rodenhizer 1987); therefore this report assumes the sludge was retained. This value closely corresponds to an estimate derived from interpreting the gamma and neutron scans of Grigsby et al. (1992). There is a substantial drop off in gamma (gross and ${ }^{137} \mathrm{Cs}$ ) and neutron activity at the $1.6 \mathrm{~m}(5.25 \mathrm{ft})$ mark corresponding to approximately $655 \mathrm{~kL}$ (173 kgals). Similar behavior was observed in the gamma and neutron traces from tanks 241-BY-108 and 241-BY-1.10; the corresponding visual cues and analytical observations in these tanks confirm the presence of sludge indicated by the gamma/neutron probes. Given the minor difference in sludge inventory obtained from the two methods (RPD $=9$ percent), the sludge inventory of tank 241-BY-105 will be taken to be $598 \mathrm{~kL}$ (158 kgal [matching the Agnew model estimate]), and the balance of the waste, $1,306 \mathrm{~kL}$ (345 kgals), will be designated saltcake. Forthcoming issues of Hanlon reports will update the change in inventory estimates. 
Table 2-4. Tank 241-BY-105 Inventory Estimate ${ }^{1,2,3}$. (2 sheets)

\begin{tabular}{|c|c|c|c|}
\hline \multicolumn{4}{|l|}{ Physical Properties } \\
\hline Total solid waste & \multicolumn{3}{|c|}{$2.97 \mathrm{E}+06 \mathrm{~kg} \quad(503 \mathrm{kgal})$} \\
\hline Heat load & \multicolumn{3}{|c|}{$2.46 \mathrm{~kW} \quad(8.39 \mathrm{E}+03 \mathrm{BTU} / \mathrm{hr})$} \\
\hline Bulk density & \multicolumn{3}{|l|}{$1.56 \mathrm{~g} / \mathrm{mL}$} \\
\hline Water wt\% & \multicolumn{3}{|l|}{42.5} \\
\hline $\begin{array}{l}\text { TOC } \\
\text { wt\% Carbon (wet) }\end{array}$ & \multicolumn{3}{|l|}{0.416} \\
\hline Ghemical constituents & molos & ppm. & kg \\
\hline $\mathrm{Na}^{+}$ & 9.55 & $1.41 \mathrm{E}+05$ & $4.18 \mathrm{E}+05$ \\
\hline $\mathrm{Al}^{3+}$ & 1.47 & $2.54 \mathrm{E}+04$ & $7.53 \mathrm{E}+04$ \\
\hline $\mathrm{Fe}^{3+}($ total $\mathrm{Fe})$ & 0.293 & $1.05 E+04$ & $3.11 E+04$ \\
\hline $\mathrm{Cr}^{3+}$ & $3.48 \mathrm{E}-02$ & $1.16 \mathrm{E}+03$ & $3.45 \mathrm{E}+03$ \\
\hline $\mathrm{Bi}^{3+}$ & $8.11 \mathrm{E}-02$ & $1.09 \mathrm{E}+04$ & $3.23 \mathrm{E}+04$ \\
\hline $\mathrm{La}^{3+}$ & $2.16 \mathrm{E}-06$ & 0.193 & 0.572 \\
\hline $\mathrm{Hg}^{2+}$ & $2.43 \mathrm{E}-05$ & 3.13 & 9.27 \\
\hline $\mathrm{Zr}$ (as $\left.\mathrm{ZrO}(\mathrm{OH})_{2}\right)$ & $1.99 \mathrm{E}-04$ & 11.6 & 34.5 \\
\hline $\mathrm{Pb}^{2+}$ & $3.80 \mathrm{E}-03$ & 505 & $1.50 \mathrm{E}+03$ \\
\hline $\mathrm{Ni}^{2+}$ & $4.57 \mathrm{E}-02$ & $1.72 \mathrm{E}+03$ & $5.11 \mathrm{E}+03$ \\
\hline $\mathrm{Sr}^{2+}$ & $2.41 \mathrm{E}-06$ & 0.135 & 0.401 \\
\hline $\mathrm{Mn}^{4+}$ & $2.18 \mathrm{E}-03$ & 76.9 & 228 \\
\hline $\mathrm{Ca}^{2+}$ & 0.470 & $1.21 E+04$ & $3.59 E+04$ \\
\hline $\mathbf{K}^{+}$ & $3.00 \mathrm{E}-02$ & 752 & $2.23 E+03$ \\
\hline $\mathrm{OH}^{-}$ & 8.08 & $8.82 E+04$ & $2.62 E+05$ \\
\hline $\mathrm{NO}_{3}^{-}$ & 4.98 & $1.98 \mathrm{E}+05$ & $5.88 \mathrm{E}+05$ \\
\hline $\mathrm{NO}_{2}^{-}$ & 1.21 & $3.59 \mathrm{E}+04$ & $1.06 \mathrm{E}+05$ \\
\hline $\mathrm{CO}_{3}^{2-}$ & 0.482 & $1.86 \mathrm{E}+04$ & $5.50 \mathrm{E}+04$ \\
\hline $\mathrm{PO}_{4}^{3-}$ & 0.173 & $1.06 \mathrm{E}+04$ & $3.13 E+04$ \\
\hline
\end{tabular}


Table 2-4. Tank 241-BY-105 Inventory Estimate ${ }^{1,2,3}$. (2 sheets)

\begin{tabular}{|c|c|c|c|}
\hline Ghemical gonstitients & moler & ppm & $\mathrm{kg}$ \\
\hline $\mathrm{SO}_{4}{ }^{2-}$ & 0.190 & $1.17 \mathrm{E}+04$ & $3.47 \mathrm{E}+04$ \\
\hline $\mathrm{Si}\left(\right.$ as $\left.\mathrm{SiO}_{3}{ }^{2-}\right)$ & 0.172 & $3.11 \mathrm{E}+03$ & $9.21 \mathrm{E}+03$ \\
\hline $\mathbf{F}$ & $9.48 \mathrm{E}-02$ & $1.16 \mathrm{E}+03$ & $3.43 E+03$ \\
\hline $\mathrm{Cl}^{-}$ & 0.107 & $2.43 E+03$ & $7.21 \mathrm{E}+03$ \\
\hline citrate & $1.61 \mathrm{E}-02$ & $1.95 E+03$ & $5.79 \mathrm{E}+03$ \\
\hline $\mathrm{EDTA}^{4}$ & $3.61 \mathrm{E}-03$ & 667 & $1.98 \mathrm{E}+03$ \\
\hline HEDTA $^{3-}$ & $4.87 \mathrm{E}-04$ & 85.7 & 254 \\
\hline glycolate & $1.13 E-02$ & 545 & $1.62 \mathrm{E}+03$ \\
\hline acetate & $2.15 \mathrm{E}-02$ & 813 & $2.41 \mathrm{E}+03$ \\
\hline oxalate & $1.85 \mathrm{E}-06$ & 0.105 & 0.310 \\
\hline DBP & $1.71 \mathrm{E}-02$ & $2.92 \mathrm{E}+03$ & $8.65 E+03$ \\
\hline Butanol & $1.71 \mathrm{E}-02$ & 812 & $2.41 \mathrm{E}+03$ \\
\hline $\mathrm{NH}_{3}$ & $7.00 \mathrm{E}-03$ & 76.4 & 227 \\
\hline $\mathrm{Fe}(\mathrm{CN})_{6}^{4-}$ & $2.21 \mathrm{E}-02$ & $3.83 E+03$ & $1.14 \mathrm{E}+04$ \\
\hline \multicolumn{4}{|l|}{ Radiological gonstitivents. } \\
\hline $\mathrm{Pu}$ & & $7.50 \mathrm{E}-02(\mu \mathrm{Ci} / \mathrm{g})$ & $3.70(\mathrm{~kg})$ \\
\hline $\mathrm{U}$ & $0.115(\mathrm{M})$ & $1.26 \mathrm{E}+03(\mu \mathrm{g} / \mathrm{g})$ & $5.22 \mathrm{E}+04(\mathrm{~kg})$ \\
\hline $\mathrm{Cs}$ & $0.149(\mathrm{Ci} / \mathrm{L})$ & $95.5(\mu \mathrm{Ci} / \mathrm{g})$ & $2.83 \mathrm{E}+05(\mathrm{Ci})$ \\
\hline Sr & $8.81 \mathrm{E}-02(\mathrm{Ci} / \mathrm{L})$ & $56.6(\mu \mathrm{Ci} / \mathrm{g})$ & $1.68 \mathrm{E}+05(\mathrm{Ci})$ \\
\hline
\end{tabular}

Notes:

${ }^{1}$ Agnew et al. (1996)

'The HTCE predictions have not been validated and should be used with caution.

${ }^{3}$ Small differences appear to exist among these values and the inventories calculated from the two sets of concentrations. These differences are being evaluated. 
Figure 2-4. Tank 241-BY-105 Level History.

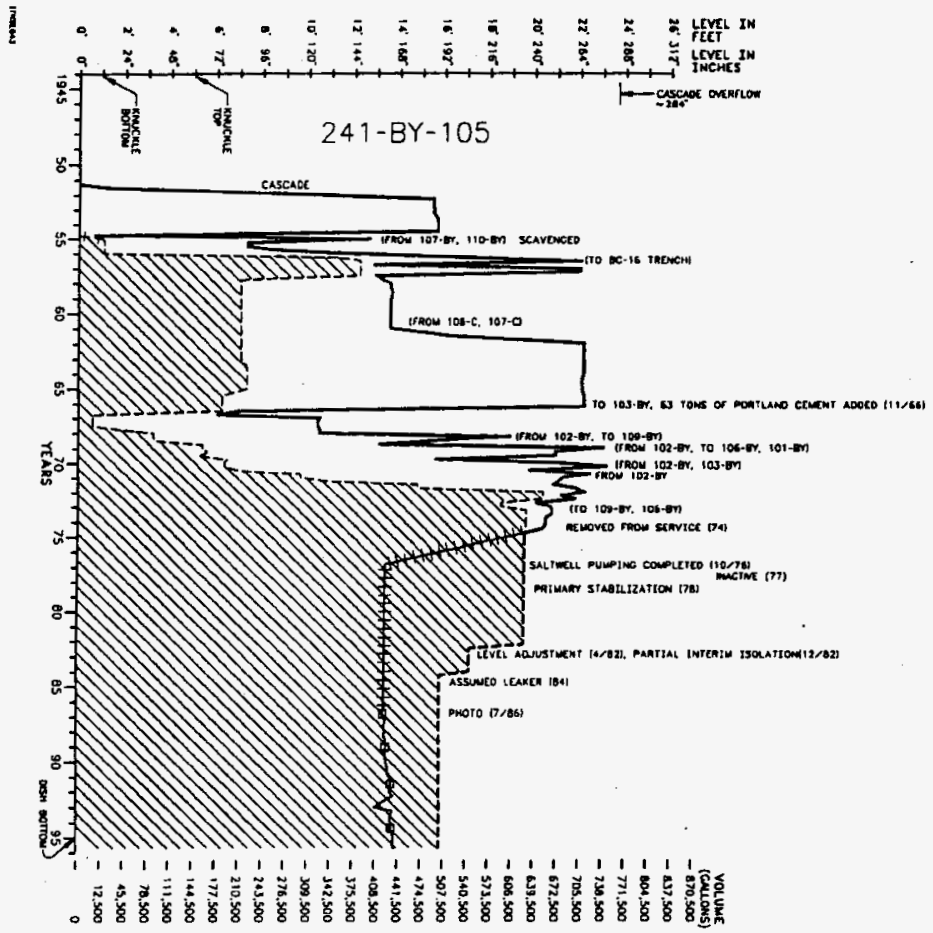




\subsubsection{Dry Wells}

Tank 241-BY-105 has three dry wells. Dry wells 22-05-01 (not active prior to 1990 but with two erratic readings $>50 \mathrm{c} / \mathrm{s}$ ) and 22-05-09 (active prior to 1990, current readings $<200 \mathrm{c} / \mathrm{s}$ ) have or have had readings greater than the $50 \mathrm{c} / \mathrm{s}$ background radiation. For a graphical representation of dry well data from January 1990 to the present, refer to Brevick et al. (1994).

\subsubsection{Internal Tank Temperatures}

Tank 241-BY-105 has two thermocouple trees: tree 1 (riser 1) has 16 thermocouples and tree 2 has 12 thermocouples to record the tank temperature. Lipnicki (1996), Drawing H-2-90342 (WHC 1987), riser configuration drawings, and the Surveillance Analysis Computer System (SACS) provide conflicting data about the location of thermocouple tree 2. For this report, it is assumed that thermocouple tree 2 is located in riser 10A (Lipnicki 1996). Elevations are known for all thermocouples except 15 and 16 (tree 1) and 7 through 12 (tree 2). Between January 1993 and June 1966, the mean temperature for thermocouple tree 1 was $36.1{ }^{\circ} \mathrm{C}\left(96.9^{\circ} \mathrm{F}\right)$, the minimum temperature was $24.82{ }^{\circ} \mathrm{C}\left(76.68^{\circ} \mathrm{F}\right)$ and the maximum temperature was $50.0^{\circ} \mathrm{C}\left(122^{\circ} \mathrm{F}\right)$. The mean temperature for thermocouple three 2 was $38.4^{\circ} \mathrm{C}\left(101.2^{\circ} \mathrm{F}\right)$, and the maximum temperature was $46.4^{\circ} \mathrm{C}\left(115.6^{\circ} \mathrm{F}\right)$ On June 3,1996 , the high temperature in the tank was $46^{\circ} \mathrm{C}\left(114^{\circ} \mathrm{F}\right)$ for tree 1 , thermocouple 1 (located in the waste); the low temperature was $25^{\circ} \mathrm{C}\left(77^{\circ} \mathrm{F}\right)$ for tree 1 , thermocouples 8 , 9 , and 12 (located in the vapor space).

Figure 2-5 shows a plot of the weekly high temperature profiles for each thermocouple tree. The plot shows that since January 1993 temperatures were consistently higher for thermocouple tree 1 (riser 1) than for tree 2 (riser 10C). The reason is believed to be the influence of the tank boundary on the thermocouple measurements. Heat transfer from the tank wall maintains a lower temperature near the tank wall (riser 10C) than at the center (riser 1). The plot also shows that since January 1993, temperatures for all risers have decreased with time. For plots of individual thermocouple readings for tank 241-BY-105, refer to Brevick et al. 1994.

\subsubsection{Tank 241-BY-105 Photographs}

The July 1982 photographic montage (see Figure 2-6) of the tank 241-BY-105 interior indicates a light tan to light brown saltcake surface with a pool of yellowish liquid in the saltwell screen. Visible equipment includes a saltwell screen, a temperature probe, and an airlift circulator descending into a depression in the crust. The tank waste volume at the time of the photographs was $2,067 \mathrm{~kL}$ (546 kgals) of waste, which corresponds to a depth of $5.2 \mathrm{~m}(17.2 \mathrm{ft})$. 
WHC-SD-WM-ER-598 Rev. 0

Figure 2-5. Tank 241-BY-105 Weekly High Temperature Plot.

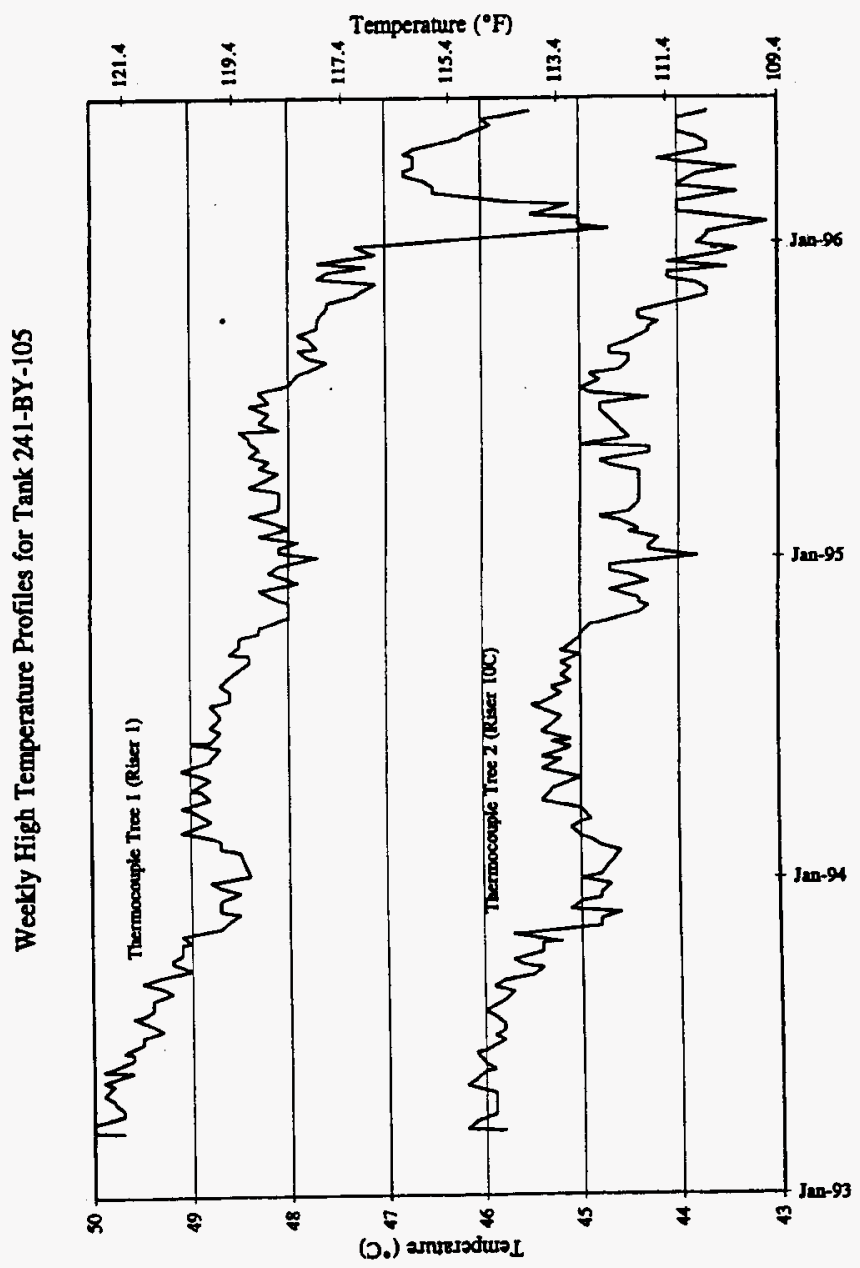


WHC-SD-WM-ER-598 Rev. 0

This page intentionally left blank. 
Figure 2-6. Photographic Montage of Tank 241-BY-105 for July 1986.

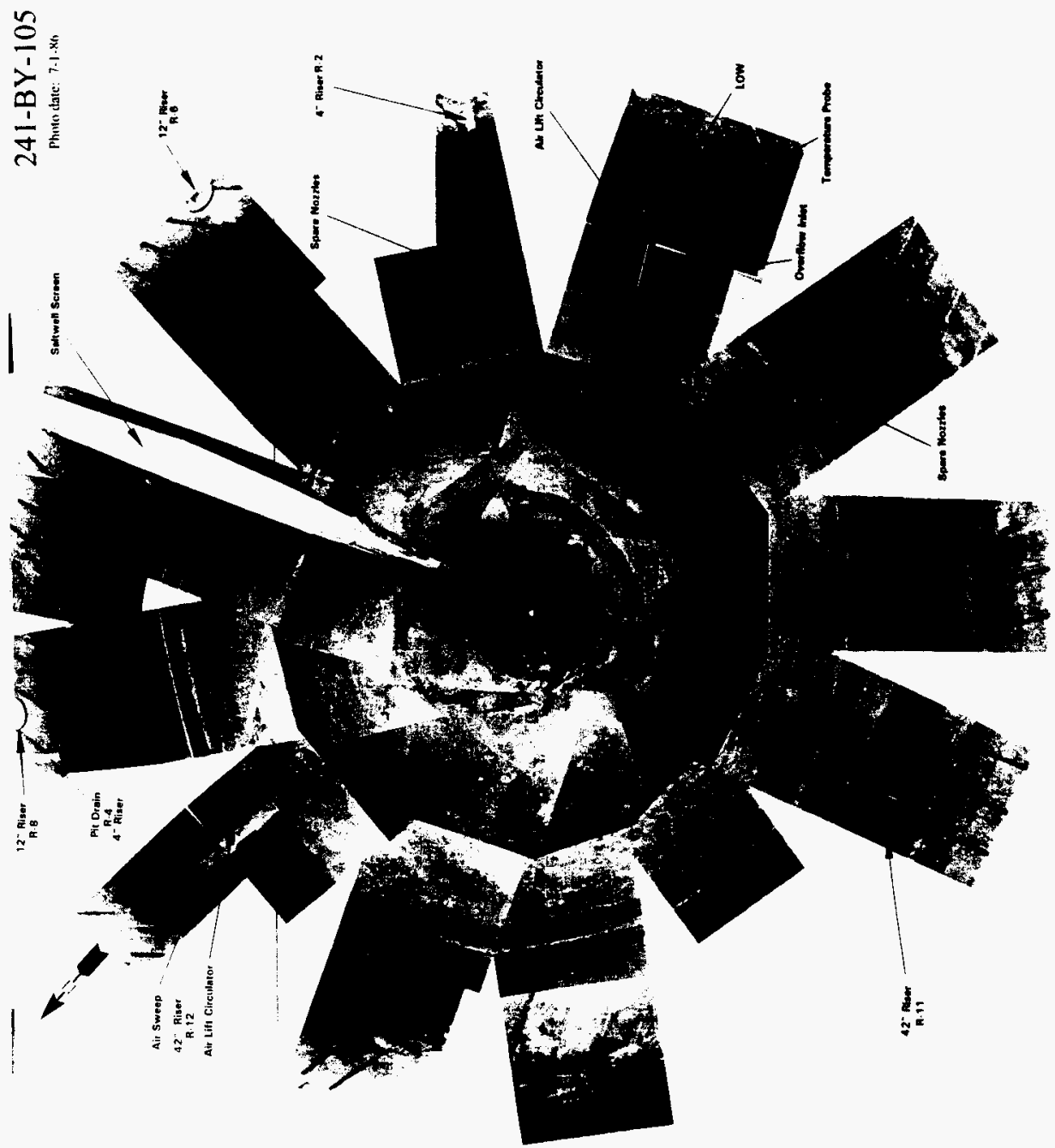


WHC-SD-WM-ER-598 Rev. 0

This page intentionally left blank. 


\subsection{TANK SAMPLING OVERVIEW}

This section describes the August through October 1995 core sampling and analysis, the March 1995 compatibility grab sample event, and the 1994 vapor sample event for tank 241-BY-105. No historical sample information was available. Analytical results for 1995 core samples, 1995 grab samples, and 1994 vapor samples are presented in Appendices A, B, and C, respectively. Table 3-1 summarizes the applicable DQOs and their respective sampling and analysis requirements. For further discussions of the sampling and analysis procedures, refer to the Tank Characterization Reference Guide (DeLorenzo et al. 1994).

\subsection{DESCRIPTION OF THE 1995 CORE SAMPLING EVENT}

One push/rotary mode core sample was collected from tank 241-BY-105 between August and October 1995. Only the top $120 \mathrm{~cm}$ (47 in.) of core 108 from riser $12 \mathrm{~A}$ was sampled because of difficulties in using the push core drilling method. This is within $25.4 \mathrm{~cm}$ (10 in.) of the level of waste after cement was added in 1966. Poor sample retrieval and flammable gas restrictions placed on all tanks during the 241-BY-105 sampling event prevented further attempts using rotary core drilling.

Segments 1, 1A, and 1B, the top $40.6 \mathrm{~cm}$ (16 in.) of the waste, were obtained in push mode. Sampling of segment $1 \mathrm{~B}$ stopped when the sampling downforce reached $2,455 \mathrm{~N}(2,800$ pounds) and a switch to a rotary sampling bit was made. Segment $1 \mathrm{C}$ was obtained at the same location starting from the waste surface: the first $31.8 \mathrm{~cm}(12.5 \mathrm{in})$ of sampling was in push mode, and the last $16.5 \mathrm{~cm}$ (6.5 in) was in rotary mode. Segments 2 and 3 were obtained in rotary mode. After segment 3 was completed, flammable gas restrictions were placed on all tanks, thereby prohibiting further rotary mode sampling. Sampling operations were stopped until a decision was made to try to complete core sampling using only push mode. Starting from the waste surface again, segments $1 R(R=$ resample), $1 A R, 2 R$ and 2AR were obtained before a hard material was encountered, and sampling was abandoned.

As a result of these difficulties, tank safety program personnel were consulted, and a decision was made to perform only the safety screening and total organic carbon analysis on these partial core samples (Sasaki 1996b). Consequently, the safety screening, ferrocyanide, organic, and historical data quality objectives (DQOs) for this tank (Sasaki 1995) were not fully met.

Nitrogen gas was used to maintain hydrostatic head pressure during sampler changeout. Water was used to wash the drill string between core sampling operations. A tracer (lithium bromide) was added to the wash water to gauge contamination of the segments by the wash water. A field blank obtained during the sampling operation and a lithium bromide blank were sent to the 222-S Laboratory for analysis. 
Table 3-1. Integrated Requirements for Tank 241-BY-105. ${ }^{1}$

\begin{tabular}{|c|c|c|c|}
\hline Sampling & Appicable 000 s & Sampling Requirements & Ipplicable References \\
\hline $\begin{array}{l}\text { Push/Rotary } \\
\text {-mode core } \\
\text { sampling }\end{array}$ & $\begin{array}{l}\text { SAFETY SCREENING } \\
\text { - Energetics } \\
\text { - Moisture Content } \\
\text { - Total Alpha } \\
\text { - Flammable Gas } \\
\text { FERROCYANIDE } \\
\text { ORGANIC } \\
\text { SAFETY TEST PLAN } \\
\text { HISTORICAL } \\
\text { PRETREATMENT }\end{array}$ & $\begin{array}{l}\text { Core samples from a } \\
\text { minimum of two risers } \\
\text { separated radially to the } \\
\text { maximum extent } \\
\text { possible. }\end{array}$ & $\begin{array}{l}\text { Dukelow et al. (1995) } \\
\text { Meacham et al. (1994) } \\
\text { Turner et al.(1995) } \\
\text { Meacham (1995) } \\
\text { Simpson and McCain } \\
\text { (1995) } \\
\text { Kupfer et al. (1995) }\end{array}$ \\
\hline $\begin{array}{l}\text { Grab } \\
\text { sampling }\end{array}$ & COMPATIBILITY & 3 grab samples & Fowler (1995) \\
\hline Vapor & $\begin{array}{l}\text { SAFETY SCREENING } \\
\text { GENERIC VAPOR }\end{array}$ & $\begin{array}{l}\text { Multiple samples from } \\
\text { the dome space }\end{array}$ & $\begin{array}{l}\text { Dukelow et al. (1995) } \\
\text { Osborne et al. (1994) }\end{array}$ \\
\hline
\end{tabular}

Note:

$$
\text { 'Sasaki (1995) }
$$

\subsubsection{Sample Handling}

A portion of core 108 was received by the Westinghouse Hanford Company 222-S Laboratory. Samples were extruded between September 11 and October 12, 1995. All core samples were manually homogenized prior to analysis by the 222-S Laboratory. The sample was composed of 3 segments identified as samples 95-197 to 95-199. No liner liquid was collected for any segments or subsegments. Drainable liquid was observed in segments 1 , $1 \mathrm{~A}, 1 \mathrm{AR}$, and $2 \mathrm{AR}$. 
Segments 1A, 1B, 1AR, and 2AR were collected separately as partial segments. The letters $A$ and $B$ denote the relative position of the segment portion; A was at the top of the segment, and $B$ was at the bottom. As stated previously, the letter $R$ identifies resampled segments.

Table 3-2 describes the segments obtained from core 108 , including segment numbers, phase (solid or liquid), color, texture, and amount of material recovered.

\subsubsection{Sample Analysis}

The analytical data provided by the analysis of core 108 were limited to the requirements of the safety program (total alpha activity, energetics, water content, flammable gas, lithium and bromide), TOC, and analysis of additional anions and metals obtained on an opportunistic basis as a result of primary safety analyses for bromide and lithium hydrostatic head fluid intrusion (Kristofzski 1995).

Core 108 was analyzed at the Westinghouse Hanford Company 222-S Laboratory. All solid sample analyses were performed on homogenized samples. Weight percent water was determined by thermogravimetric analysis (TGA). The fuel content of the waste was determined by differential scanning calorimetry (DSC). Metals were measured using ICP/atomic emission spectroscopy (AES); prior to analysis the subsamples were prepared by fusion and acid digestion. Anions were measured on water-leached samples using IC. Total organic carbon was measured using hot persulfate oxidation and coulometry. Total alpha activity and gamma energy analysis was performed on fusion-digested samples. Density was measured using centrifugation. Secondary safety screening analyses performed were cyanide and the adiabatic calorimetry reactive system screening tool tests. Table 3-3 provides information about the laboratory procedures used in the analysis of these samples.

A complete data set including the segments, segment portions, individual sample numbers, and the analyses performed on each sample is included in Appendix A.

\subsection{DESCRIPTION OF THE 1995 GRAB SAMPLE EVENT}

On March 22, 1995, two liquid grab samples were obtained from riser 5. Sampling and analysis were conducted in accordance with Data Quality and Objectives for the Waste Compatibility Program (Fowler 1995) and Tank 241-BY-105 Tank Characterization Plan (Schreiber 1995). Analyses included volume percent solids, specific gravity, energetics, radionuclides, and selected metals and anions. Results are included in Appendix C. The results compare favorably with drainable liquid results from the September 1995 core sampling event (see Section 5.0). 
Table 3-2. Core 108 Sample Description.'

\begin{tabular}{|c|c|c|c|c|c|}
\hline \multirow[b]{2}{*}{ Segrinent } & \multirow{2}{*}{ Sample } & \multirow{2}{*}{$\begin{array}{l}\text { Expected } \\
\text { Sample. } \\
\text { Eength } \\
\text { (em) }\end{array}$} & \multicolumn{2}{|c|}{ Sample Weight (g) } & \\
\hline & & & Solid & Giquid & Segment Description. \\
\hline 1 & $95-197$ & 24 & 56.2 & 123.0 & $\begin{array}{l}\text { Extruded } 15 \mathrm{~cm} \text { of sample. Sample } \\
\text { was a beige slurry with crystalline } \\
\text { solids. Drainable liquid was } \\
\text { recovered. }\end{array}$ \\
\hline $1 \mathrm{~A}$ & $95-197 \mathrm{~A}$ & 11.5 & 51.1 & 50.8 & $\begin{array}{l}\text { Extruded } 2.5 \mathrm{~cm} \text { of sample. Sample } \\
\text { was beige, a mixture of sludge and } \\
\text { crystalline solids. Drainable liquid } \\
\text { was recovered. }\end{array}$ \\
\hline $1 \mathrm{~B}$ & $95-197 \mathrm{~B}$ & 5.0 & 72.1 & 0 & $\begin{array}{l}\text { Extruded } 5 \mathrm{~cm} \text { of sample. Sample } \\
\text { was beige, a mixture of sludge a } \\
\text { crystalline solids. No drainable liquid } \\
\text { was recovered. }\end{array}$ \\
\hline $1 \mathrm{C}$ & $95-197 \mathrm{C}$ & 48 & $<2$ & $<5 \mathrm{~mL}$ & $\begin{array}{l}\text { Extruded less than } 5 \mathrm{~mL} \text { drainable } \\
\text { liquid; less than } 2 \mathrm{~g} \text { beige solids } \\
\text { observed on the end of the sampler } \\
\text { piston. Insufficient sample was } \\
\text { recovered for analysis. }\end{array}$ \\
\hline 2 & $95-198$ & 48 & 18.5 & 0 & $\begin{array}{l}\text { Extruded about } 2.5 \mathrm{~cm} \text { of gray/brown } \\
\text { slushy looking material. The material } \\
\text { appeared crystalline and wet, but } \\
\text { could be broken up with the tip of a } \\
\text { spatula. No drainable liquid was } \\
\text { recovered. }\end{array}$ \\
\hline 3 & $95-199$ & 48 & 43.0 & $<15 \mathrm{~mL}$ & $\begin{array}{l}\text { Near the end of the extrusion, } \\
\text { extruded a small amount of } \\
\text { gray/brown slushy looking material } \\
\text { that appeared similar to segment } 2 \text { of } \\
\text { this core. The material ranged from } \\
\text { clear crystals to dark chunks } \\
\text { resembling small pieces of gravel. } \\
\text { Observed less than } 15 \mathrm{~mL} \text { of } \\
\text { drainable liquid which could not be } \\
\text { collected separately. }\end{array}$ \\
\hline IR & $95-197 R$ & 18 & 240.0 & 0 & $\begin{array}{l}\text { About } 23 \mathrm{~cm} \text { of wet saltcake were } \\
\text { extruded. The first half was light } \\
\text { brown and looked like a light colored } \\
\text { brown sugar. The second half was a } \\
\text { little darker, crystalline and fell off in } \\
\text { chunks onto the sample tray. The } \\
\text { solids were wet and broke apart } \\
\text { easily, but there was no drainable } \\
\text { liquid. }\end{array}$ \\
\hline
\end{tabular}


Table 3-2. Core 108 Sample Description. ${ }^{1}$

\begin{tabular}{|c|c|c|c|c|c|}
\hline (4. & 1.6 .1 .8 .1$. & $\begin{array}{l}\text { Expected } \\
\text { Sample }\end{array}$ & Sample & Verght $(\mathrm{g})$ & \\
\hline Segmerit & $1 \mathrm{D}$ & $(.6 \mathrm{H})$ & Solld & Liquid & Segment Description \\
\hline $1 \mathrm{AR}$ & 95-197AR & 1.3 & 14.5 & 149.5 & $\begin{array}{l}\text { Cloudy light brown drainable liquid } \\
\text { was collected when the sampler valve } \\
\text { was opened. A small amount of light } \\
\text { brown crystalline solids were extruded } \\
\text { in about the first } 10 \mathrm{~cm} \text {. Wet light } \\
\text { brown crystalline solids (similar to } \\
\text { solids in segment } 1 \mathrm{~A} \text {, but wetter) } \\
\text { were extruded in the last } 5 \mathrm{~cm} \text {. }\end{array}$ \\
\hline $2 \mathrm{R}$ & $95-198 R$ & 24 & 105.9 & 0 & $\begin{array}{l}\text { A small amount of brown liquid with } \\
\text { some solids came out of the sampler } \\
\text { when the valve was opened. Slushy } \\
\text { crystalline solids and some liquid were } \\
\text { extruded in the last } 15 \text { to } 18 \mathrm{~cm} \text { of the } \\
\text { extrusion. Solids and liquids were } \\
\text { brown with a small amount of light } \\
\text { colored soils mixed in. Liquid could } \\
\text { not be collected separate from the } \\
\text { solids. }\end{array}$ \\
\hline $2 \mathrm{AR}$ & $95-198 \mathrm{AR}$ & 24 & 126.6 & 306.8 & $\begin{array}{l}\text { Cloudy light brown liquid drained } \\
\text { from the sampler when the sample } \\
\text { valve was opened. A small amount of } \\
\text { solids were extruded in the first } 3 \mathrm{~cm} \text {. } \\
\text { Yellowish-brown drainable liquid was } \\
\text { observed. } 10 \text { to } 13 \mathrm{~cm} \text { of saltcake } \\
\text { were extruded at the end. Solids were } \\
\text { a mix of light and medium brow. The } \\
\text { texture was similar to segment } 1 \mathrm{R} \text { and } \\
\text { lAR. Solids contained a few dark } \\
\text { hard chunks that looked like rocks. }\end{array}$ \\
\hline
\end{tabular}

Note:

'Sasaki (1996a) 
Table 3-3. Analytical Procedures'.

\begin{tabular}{|c|c|c|c|}
\hline (1) Analysis & Instriment & $\begin{array}{l}\text { Preparation } \\
\text { Procedure. }\end{array}$ & Procedure Number \\
\hline Energetics by DSC & $\begin{array}{l}\text { Mettler }^{2} \\
\text { Perkin-Elmer }\end{array}$ & Direct & $\begin{array}{l}\text { LA-514-113, Rev. B-1 } \\
\text { LA-514-114, Rev. B-0 }\end{array}$ \\
\hline $\begin{array}{l}\text { Percent water by } \\
\text { TGA }\end{array}$ & $\begin{array}{l}\text { Mettler }^{2} \\
\text { Perkin-Elmer }^{3}\end{array}$ & Direct & $\begin{array}{l}\text { LA-560-112, Rev. A-2 } \\
\text { LA-514-114, Rev. B-0 }\end{array}$ \\
\hline Total alpha activity & $\begin{array}{l}\text { Alpha proportional } \\
\text { counter }\end{array}$ & $\begin{array}{l}\text { LA-549-141, Rev. } \\
\text { D-0 }\end{array}$ & LA-508-101, Rev. D-2 \\
\hline Flammable gas & $\begin{array}{l}\text { Combustible gas } \\
\text { analyzer }\end{array}$ & Direct & $\begin{array}{l}\text { WHC-IP-0030 } \\
\text { IH } 1.4 \text { and IH-2.1 }\end{array}$ \\
\hline TOC & Coulometer & Persulfate oxidation & LA-342-100, Rev. C-0 \\
\hline Metals by ICP/AES & $\begin{array}{l}\text { Inductively coupled } \\
\text { plasma spectrometer }\end{array}$ & $\begin{array}{l}\text { LA-549-141, Rev. } \\
\text { D-0 }\end{array}$ & $\begin{array}{l}\text { LA-505-151, Rev. D-2 } \\
\text { LA-505-161, Rev. A-1 }\end{array}$ \\
\hline Anions by IC & Ion chromatograph & & $\begin{array}{l}\text { LA-533-105, Rev. C-2 } \\
\text { LA-533-105, Rev. D-1 }\end{array}$ \\
\hline Cyanide & Microdistillation & Direct & LA-695-102, Rev. E-0 \\
\hline $\begin{array}{l}\text { Reactive System } \\
\text { Screening Tool }\end{array}$ & $\begin{array}{l}\text { Adiabatic } \\
\text { calorimeter }\end{array}$ & Direct & WHC-SD-WM-TP-104 \\
\hline
\end{tabular}

Notes:

\footnotetext{
'Sasaki (1995)

${ }^{2}$ Mettler is registered trademark of Mettler Electronics, Anaheim, California.

${ }^{3}$ Perkin-Elmer is a registered trademark of Perkins Research and Manufacturing Company, Inc., Canoga Park, Califormia.

${ }^{4} \mathrm{WHC}$ (1992)

IH 1.4, Industrial Hygiene Direct Reading Instrument Survey

IH 2.1, Standard Operating Procedure, MSA Model 260 Combustible Gas and Oxygen Analyzer.

SBechtold (1992)
} 


\subsection{VAPOR ANALYSIS DESCRIPTION}

Tank 241-BY-105 headspace gas and vapor samples were collected and analyzed to help determine the potential risks of fugitive emissions to tank farm workers. The drivers and objectives of waste tank headspace sampling and analysis are discussed in Program Plan for the Resolution of Tank Vapor Issues (Osborne and Huckaby 1994). Tank 241-BY-105 headspace was sampled in May 1994 in accordance with the Safety Assessment for Gas Sampling All Ferrocyanide Tanks (Farley 1991) using the in situ sampling method. However, because the in situ sample volume flow measurement used was less accurate than the vapor sampling system method (Huckaby et al. 1995), and other not fully understood discrepancies existed between the in situ sampling and vapor sampling system methods, these sample results are suspect and are not reported here (Huckaby 1994).

Tank 241-BY-105 was vapor sampled in July 1994 using the vapor sampling system method. Samples were collected in accordance with the Data Quality Objectives for Generic In-Tank Health and Safety Issue Resolution (Osborne et al. 1994). Samples are thought to represent the tank headspace when the tank was sampled (Meacham et al. 1995). The sample analyses were designed to provide a reasonably accurate and complete characterization of the significant headspace constituents. No assessment was made of how tank 241-BY-105 headspace composition changed, although studies of other tanks suggest that composition changes probably occur very slowly in passively ventilated tanks such as tank 241-BY-105 (Huckaby and Story 1994). Section 4.5 discusses the results.

\subsection{HISTORICAL SAMPLES}

No historical records indicating that the tank has been previously sampled and analyzed were available for tank 241-BY-105. 
WHC-SD-WM-ER-598 Rev. 0

This page intentionally left blank. 


\subsection{ANALYTICAL RESULTS}

This section provides the analytical results associated with the September 1995 sampling of tank 241-BY-105 and selected vapor results from the 1994 vapor sampling event. See Section 5.0 for comparisons with March 1995 grab sample analyses.

Except as noted in Section 3.0, sampling and analysis were performed as directed in the Tank 241-BY-105 Rotary Mode Core Sampling and Analysis Plan (SAP) (Sasaki 1995). The SAP integrated all documents related to sampling and analytical requirements including applicable DQOs. Sampling and analytical requirements were taken from the safety screening DQO (Dukelow et al. 1995), the ferrocyanide DQO (Meacham et al. 1994), the historical model evaluation data requirements (Simpson and McCain 1995), the organic DQO (Turner et al. 1995), and the safety program test plan (Meacham 1995). Because of drilling difficulties, only the top $1.2 \mathrm{~m}(3.94 \mathrm{ft})$ of one core sample from riser $12 \mathrm{~A}$ were taken, and only safety screening and total organic carbon analyses were performed. Analysis of the samples was performed at the Westinghouse Hanford Company 222-S Laboratory.

\subsection{DATA PRESENTATION}

Analytical results are indexed in Table 4-1. Analytical data may also be found in Sasaki (1996a) or the Tank Characterization Database. ${ }^{1}$

Table 4-1. Analytical Data Tables.

\begin{tabular}{|l|l|}
\hline \multicolumn{1}{|c|}{ Data lype. Uocation } & Table 4-2 \\
\hline Chemical Data Summary & Table 4-3 \\
\hline 1994 Vapor Space Analytical Data & Table 4-4 \\
\hline Flammable Gas & Table A-47 \\
\hline Percent Moisture & Table A-48 \\
\hline Energetics & Appendix A \\
\hline September 1995 Push Core Analytical Data & Appendix C \\
\hline March 1995 Grab Sample Results & Appendix B \\
\hline Hydrostatic Head Fluid contamination check data & \\
\hline
\end{tabular}

'Described in Adams (1996). The database is accessible on the internet at URL: http: lltwins.pnl.gov:8001/refmain.htm 
Data from core 108 samples were combined to calculate a mean for each segment and an overall mean based on the three segment means. Restricted maximum likelihood (REML) methods were used to calculate means and a relative standard deviation (RSD) of the mean for each analyte (Hartley et al. 1995). The estimates are based on a statistical analysis of variance (ANOVA) method. Projected inventories were not calculated because data could only be obtained for the top three segments. The usefulness of mean concentrations and uncertainty estimates is limited because of the incomplete data set. Based on tank transfer information and Agnew et al. (1996), the lower segments in the tank are not assumed to be similar to the three segments sampled. Drainable liquid results were separated from the solids results, and separate means and RSDs were calculated.

\subsection{CHEMICAL DATA SUMMARY}

Table 4-2 shows the tank average (REML mean) and RSD analytical results for metals, anions, total alpha and total organic carbon. Segment results and drainable liquid results are shown in Appendix A.

\subsubsection{Inductively Coupled Plasma and Ion Chromatography Analyses}

Metals and cations were detected using ICP/AES analyses. The only metals found at a concentration of $10,000 \mu \mathrm{g} / \mathrm{g}$ or higher were aluminum and sodium. All other metals and cations were found at mean concentrations less than $750 \mu \mathrm{g} / \mathrm{g}$. Tables A-1 to A-36 show segment level ICP analytical results. Anions in all segments were detected using IC analyses. High concentrations $(>10,000 \mu \mathrm{g} / \mathrm{g}$ ) of nitrate, sulfate, and oxalate were observed. The nitrate/nitrite ratio is about 52:1 (mass basis). Segment level IC analytical results are shown in Tables A-37 to A-43.

\subsubsection{Total Alpha}

Total alpha analyses were performed on a fusion digested sample with an alpha proportional counter according to procedure LA-508-101, Rev. D-2. All total aipha results were well below the DQO notification limit of $33.1 \mu \mathrm{Ci} / \mathrm{g}$. Based on a density of $1.86 \mathrm{~g} / \mathrm{mL}$, the saltcake solids average for total alpha was $0.019 \mu \mathrm{Ci} / \mathrm{g}$, and the RSD was 14 percent. The highest observed value (average of sample and duplicate) was $0.031 \mu \mathrm{Ci} / \mathrm{g}$ for sample number S95T003403 (segment 2). The upper limit to a one-sided 95 percent confidence interval on the mean for this sample was $0.043 \mu \mathrm{Ci} / \mathrm{g}$; approximately 0.13 percent of the notification threshold. Table A-44 shows segment data for total alpha from tank 241-BY-105. Four RPD values exceeded 20 percent. However, no reruns were requested because all results were well below the notification limit. 
Table 4-2. Chemical Data Summary for Tank 241-BY-105 Saltcake.' (2 sheets)

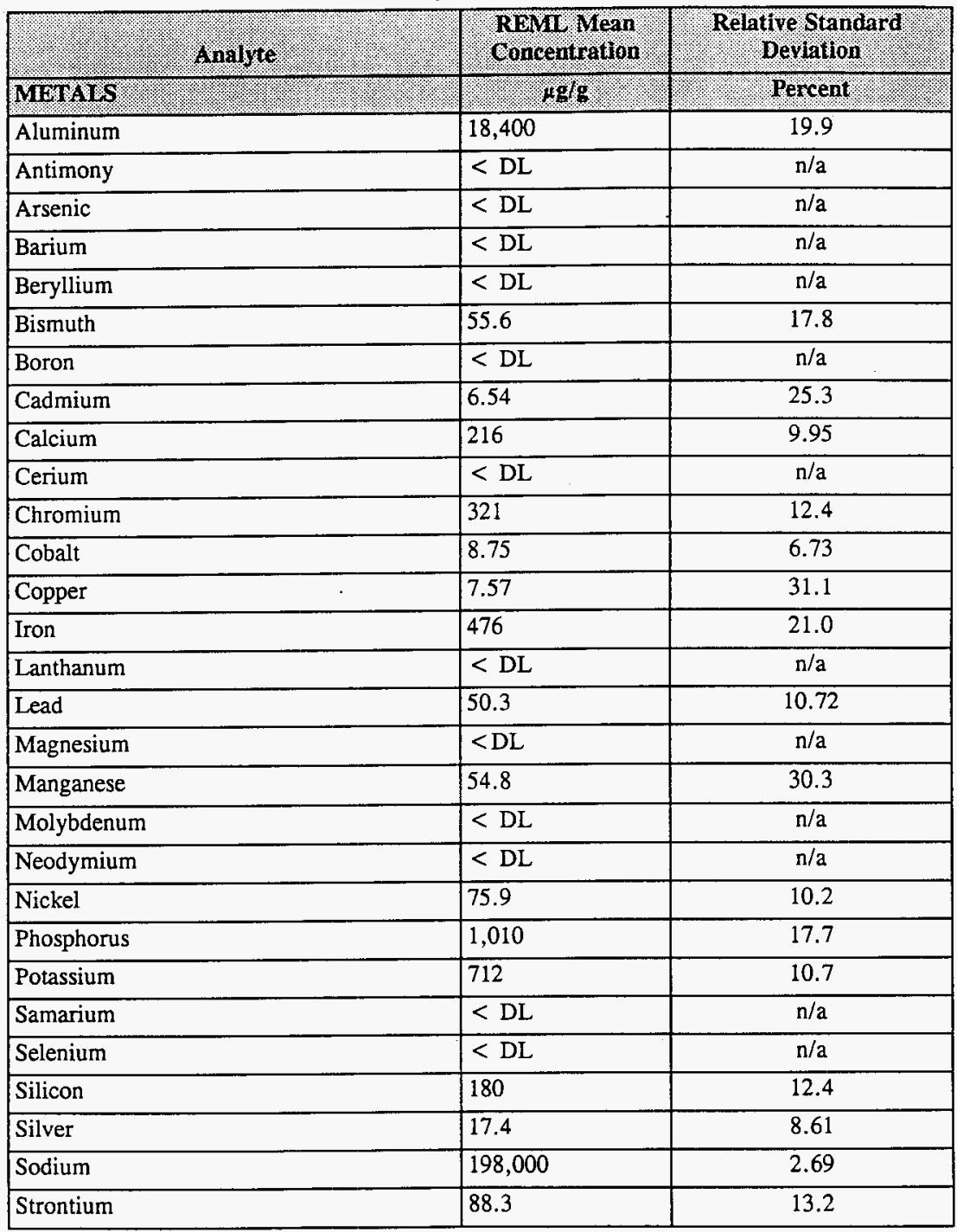


Table 4-2. Chemical Data Summary for Tank 241-BY-105 Saltcake. ${ }^{1}$ (2 sheets)

\begin{tabular}{|c|c|c|}
\hline Analyte & $\begin{array}{l}\text { REMT Mean } \\
\text { Concentration }\end{array}$ & $\begin{array}{l}\text { Relative Standard } \\
\text { Deviation }\end{array}$ \\
\hline METALS (Cont'd) & $\mu \mathrm{g} / \mathrm{g}$ & Percent \\
\hline Sulfur & 3,140 & 30.6 \\
\hline Thallium & $<\mathrm{DL}$ & $\mathrm{n} / \mathrm{a}$ \\
\hline Titanium & $<\mathrm{DL}$ & $\mathrm{n} / \mathrm{a}$ \\
\hline Uranium & 261 & 8.64 \\
\hline Vanadium & $<\mathrm{DL}$ & $\mathrm{n} / \mathrm{a}$ \\
\hline Zinc & 36.8 & 22.6 \\
\hline Zirconium & 5.23 & 8.29 \\
\hline ANIONS & $1.49 / 9$ & Percent. \\
\hline Chloride & 897 & 30.7 \\
\hline Cyanide & 4.89 & 14.5 \\
\hline Fluoride & 4,100 & 29.6 \\
\hline Nitrate & 491,000 & 15.8 \\
\hline Nitrite & 9,410 & 14.4 \\
\hline Oxalate & 11,300 & 41.9 \\
\hline Phosphate (total) & 4,890 & 46.8 \\
\hline Sulfate & 10,600 & 36.2 \\
\hline RADIONUCLDES & $.1 . \mathrm{Cig}$ & Percent \\
\hline Total alpha & 0.0168 & 15.3 \\
\hline CARBON & $\rho \mathrm{g} \mathrm{C} \mathrm{g}$ & Percent: \\
\hline Total organic carbon & 3,250 & 36.0 \\
\hline MOISTURE CONTENT: & Weight Percent & Percent \\
\hline Water & 16.1 & 25.9 \\
\hline
\end{tabular}

Notes:

$\mathbf{n} / \mathbf{a}=$ not applicable

$<\mathrm{DL}=$ below analytical detection limits

'Sasaki (1996) 


\subsubsection{Total Organic Carbon}

Total organic carbon for the solids samples ranged between $668 \mu \mathrm{g} \mathrm{C} / \mathrm{g}$ to $6,970 \mu \mathrm{g} \mathrm{C} / \mathrm{g}$ (wet). The mean concentration was $3,250 \mu \mathrm{g} \mathrm{C} / \mathrm{g}$ (wet). The mean TOC concentration on a dry basis is $3,680 \mu \mathrm{g} \mathrm{C} / \mathrm{g}$, approximately 10 percent of the notification threshold. For drainable liquids TOC ranged between $1,920 \mu \mathrm{g} \mathrm{C} / \mathrm{mL}$ and $2,240 \mu \mathrm{g} \mathrm{C} / \mathrm{mL}$ with a mean concentration of $2,090 \mu \mathrm{g} \mathrm{C} / \mathrm{mL}$ (see Table A-45).

\subsubsection{Cyanide}

Cyanide analysis was performed on two samples that exceeded the notification limit for exothermic reactions. Results for these samples were 4.9 and $10.7 \mu \mathrm{g} / \mathrm{g}$, well below the $39,000 \mu \mathrm{g} / \mathrm{g}$ notification limit for cyanide.

\subsubsection{Separable Organic Layer}

No evidence of a separable organic layer was observed in any sample.

\subsection{PHYSICAL DATA SUMMARY}

Physical analyses required by the sampling and analysis plan (Sasaki 1995) included TGA, DSC, and bulk density. Percent solids, particle size, and rheology were not requested and not performed.

\subsubsection{Thermogravimetric Analysis}

In a TGA, the mass of a sample is measured while its temperature is increased at a constant rate. A gas, such as nitrogen or air, is passed over the sample during the heating to remove any gaseous matter. Any decrease in the mass of a sample represents a loss of gaseous matter from the sample through evaporation or through a reaction that forms gas phase products. The decrease in mass is assumed to be caused by a moisture loss.

Weight percent water by TGA was performed by the 222-S Laboratory under a nitrogen purge using procedures LA-560-112 and LA-514-114.

Table A-47 shows the TGA percent water data for tank 241-BY-105 (16.1 weight percent with an RSD of 25.9 percent). No trends were observed in the data. Seven samples exhibited percent water means below the safety screening DQO notification limit of 17 weight percent. The fact that several samples were below 17 weight percent does not in itself constitute an unsafe condition. The energetics values for these samples must also exceed the safety screening notification limits for the tank to be considered unsafe. Solids average 
segment results ranged from 5.73 to 26.96 weight percent water. Drainable liquid average results ranged from 46.27 to 54.22 weight percent water. Triplicate analyses were run for five samples with the highest RPDs; however, results did not improve indicating that samples within a segment were not homogeneous.

Section 4.3 .4 briefly discusses the tracer used to determine whether a sample has been contaminated. There were no indications that wash water contamination occurred. For more information regarding the correction method, refer to Winkelman (1996).

Potentially, the boiling performed as part of the in-tank solidification process could have contributed to unusual moisture distributions. Other tanks in BY farm, which were part of that process and or the self-boiling tanks in S Farm have exhibited unexpected behavior. However, the addition of Portland cement makes this particular tank even more atypical. Additional and more complete samples (top to bottom) are necessary to assess the moisture content and waste distribution in the tank.

\subsubsection{Differential Scanning Calorimetry}

In a DSC analysis, heat absorbed or emitted by a substance is measured while the temperature of the substance is increased. The onset temperature for an endothermic event (characterized by or causing the absorption of heat) or exothermic event (characterized by or causing the release of heat) is measured with thermocouples and displayed graphically.

The DSC analyses were performed under a nitrogen atmosphere using procedure LA-514-113, Rev. B-1 and a Mettler ${ }^{\mathrm{TM}}$ Model 20 differential scanning calorimeter and procedure LA-514-114, Rev. B-0 and Perkin-Elmer ${ }^{\mathrm{TM}}$ equipment. No quality control problems were noted.

The DSC results are provided in Appendix A. The sample number, sample location, sample weight, temperature at maximum enthalpy change, and the magnitude of the enthalpy change are provided for each transition. A negative enthalpy change in Table A-48 indicates an energy release or exotherm. A positive enthalpy change indicates energy absorbed or an endotherm.

The first transition, which was ambient to approximately $150^{\circ} \mathrm{C}$, represented the endothermic reaction associated with the evaporation of free and interstitial water. The enthalpy changes for the endotherms ranged from $240 \mathrm{~J} / \mathrm{g}$ to over $1,300 \mathrm{~J} / \mathrm{g}$.

In the second transition, which took place between 180 and $330{ }^{\circ} \mathrm{C}$, endothermic and exothermic reactions were observed. The enthalpy changes for endotherms were not as large as in the first transition (between 15 and $400 \mathrm{~J} / \mathrm{g}$ ) and probably represented the energy (heat) required to remove bound water from hydrated compounds such as aluminum hydroxide or to melt salts such as sodium nitrate. Such results are usually found in the upper (saltcake) portions of the core sample. Exotherms were found in three drainable liquid samples 
(enthalpy changes of $-105,-120$, and $-676 \mathrm{~J} / \mathrm{g}$ ) and only one very dry solid sample $(-760 \mathrm{~J} / \mathrm{g})$. This finding is generally consistent with the hypothesis that states that higher energy organics are mostly soluble and usually found in liquid, and lower energy organics are found in the solid waste matrices. The exotherms were probably caused by the fuel components of the sample reacting with the nitrate salts.

The DSC results are reported on a wet weight basis. The safety screening DQO, however, requires that exothermic reactions be evaluated on a dry weight basis to make a decision about tank safety. The dry weight value is calculated from the wet weight value by dividing the reported exothermic value for a subsegment by the solid fraction of the subsegment (that is, one minus the fractional percent water value for that subsegment).

Drainable liquid sample duplicate S95T003418 (1AR drainable liquid) and sample \$95T003399 (segment 3 solids) exhibited dry exotherms with enthalpy changes of $-1,465 \mathrm{~J} / \mathrm{g}$ and $-806 \mathrm{~J} / \mathrm{g}$, respectively, thereby exceeding the safety screening criteria. However, high variability was found in samples and sample duplicates. This may be attributed in part to sample heterogeneity and analytical error. The reactive system screening tool analysis was performed to further assess the two samples with high exotherms. The results showed no self-heating or gas generating response for these samples (Bechtold 1996).

The DSC responses were observed infrequently at higher temperatures (above $330^{\circ} \mathrm{C}$ ) as well (see Transitions 3 and 4 in Table 4-4). These responses were caused by one or more factors. Generally, the results were modestly exothermic; therefore, results could represent additional reactions or a carryover of a reaction that started at a lower temperature and was masked by a concurrent endotherm. However, for DSC results of this type and magnitude ( $<50 \mathrm{~J} / \mathrm{g}$ instrument drift), a more likely cause was a shift in the instrument baseline at higher temperatures. In these cases, the DSC may have indicated a response where none occurred, and observations could be artifacts of the analytical method. Endotherms were not observed at higher temperatures.

\subsubsection{Density}

Density measurements for solids and specific gravity measurements for liquids were performed on all samples (see Table A-49). The REML mean density for the samples taken was $1.86 \mathrm{~g} / \mathrm{mL}$, with a range of 1.85 to $1.98 \mathrm{~g} / \mathrm{mL}$. Because of the limited sample amounts collected, bulk density measurements could not be obtained for segment 1AR, segment 2 , and a duplicate for segment 3 . The REML mean specific gravity for drainable liquids was $1.4 \mathrm{~g} / \mathrm{mL}$. All liquid speeific gravities were within $0.02 \mathrm{~g} / \mathrm{mL}$ range. 


\subsection{ANALYSIS FOR HYDROSTATIC HEAD FLUID CONTAMINATION}

During sampling, drill string wash water was used to clean the drill string after each core was removed. Lithium bromide was added to the wash water as a tracer, and its presence in core samples indicated contamination by the wash water. This check, through analyses for lithium and bromide, was prescribed by the SAP (Sasaki 1995). The SAP established notification limits of $100 \mu \mathrm{g} / \mathrm{g}$ for lithium and $1,200 \mu \mathrm{g} / \mathrm{g}$ for bromide.

Appendix B contains tables with lithium and bromide analytical results. None of the samples analyzed had lithium or bromide results that exceeded the notification limits. As a result, it is concluded that none of the samples analyzed were significantly contaminated by the hydrostatic head fluid.

\subsection{HEADSPACE VAPOR SAMPLING}

The safety screening DQO has established a notification limit of 25 percent of the lower flammability limit (LFL) for headspace vapors. Prior to removing core samples, tank vapors were field tested using a combustible gas meter and an organic vapor meter. Lower flammability limits of 0.0 percent were observed in risers $12 \mathrm{~A}$ and $12 \mathrm{~B}$, with 30 to $40 \mathrm{ppm}$ ammonia. The oxygen concentration was 20.9 percent. This result satisfied the safety screening requirement of $<25$ percent of the LFL. Table 4-3 provides data from Huckaby and Bratzel (1995) about headspace composition. Vapor flammability calculations from the data in Huckaby and Bratzel (1995) indicate a concentration of less than one percent of the LFL (see Table 4-4). 
Table 4-3. Selected Vapor Space Characterization Data.

\begin{tabular}{|c|c|}
\hline Analyte : & Concentration (ppmy) \\
\hline \multicolumn{2}{|c|}{ Inorgance } \\
\hline Ammonia & 43 \\
\hline Hydrogen & 47.9 \\
\hline Carbon dioxide & 94 \\
\hline Carbon monoxide & 0.38 \\
\hline Nitric oxide & 0.10 \\
\hline Nitrogen dioxide & $<0.02$ \\
\hline Nitrous oxide & 49.5 \\
\hline \multicolumn{2}{|l|}{ Organic } \\
\hline Methane & 3.8 \\
\hline Ethanenitrile & 0.081 \\
\hline Propanone (acetone) & 0.25 \\
\hline 1-Butanol & 0.70 \\
\hline n-dodecane & 0.0081 \\
\hline n-tridecane & 0.010 \\
\hline (2) & Concentrafion $(\mathrm{mg} / \mathrm{m}$ ) \\
\hline Water vapor & 14.9 \\
\hline Total non-methane organic carbon & 12.7 \\
\hline
\end{tabular}

Table 4-4. Vapor Flammability Results from 1994 Vapor Sampling and Analysis Event.

\begin{tabular}{|c|c|c|c|}
\hline Analyte: & Irt & Concentration & $\begin{array}{l}\text { Conicentration ass } \\
\text { percent of l.ril }\end{array}$ \\
\hline Hydrogen & $40,000 \mathrm{ppm}$ & $47.9 \mathrm{ppm}$ & $0.12 \%$ \\
\hline TNMOC & $46,000 \mathrm{mg} / \mathrm{m}^{3}$ & $12.7 \mathrm{mg} / \mathrm{m}^{3}$ & $0.03 \%$ \\
\hline Ammonia & $150,000 \mathrm{ppm}$ & $43 \mathrm{ppm}$ & $0.03 \%$ \\
\hline \multicolumn{3}{|l|}{ Total } & $0.18 \%$ \\
\hline
\end{tabular}

Notes:

$\begin{array}{lll}\text { LFL } & = & \text { lower flammability limit } \\ \text { TNMOC } & = & \text { total non-methane organic carbon }\end{array}$ 
WHC-SD-WM-ER-598 Rev. 0

This page intentionally left blank. 


\subsection{INTERPRETATION OF CHARACTERIZATION RESULTS}

Section 5.0 evaluates the overall quality and consistency of the available results for tank 241-BY-105. These results are assessed and compared against historical information and program requirements.

\subsection{ASSESSMENT OF SAMPLING AND ANALYTICAL RESULTS}

The subsection below evaluates sampling and analysis factors that may impact data use or interpretation. These factors are used to assess the overall data quality and consistency and to identify limitations in data use.

\subsubsection{Field Observations}

The safety screening DQO requirement (Dukelow et al. 1995) that at least two widely spaced risers be sampled was not fulfilled because of difficulties in obtaining samples by the push core method and stopping of all rotary drilling because of flammability safety issues. Only a portion of riser $12 \mathrm{~A}$, core 108 was sampled before the job was stopped. Additional samples are required to fully characterize this tank and to meet safety, historical, and ferrocyanide DQOs as set forth in the sample analysis plan; therefore, interpretation is very limited. Sample recovery was irregular and inadequate for the riser sampled. Hydrostatic head fluid intrusions were negligible for the samples taken.

\subsubsection{Quality Control Assessment}

The quality control assessment included an evaluation of the four quality control checks (blanks, duplicates, spikes, and standards) performed in conjunction with the chemical analyses. A general evaluation and summary of some key safety and characterization areas are provided in this section. Additional detail is provided in Sasaki (1996a and 1996b). DOE (1995) provides general laboratory guidance on quality control. The SAP (Sasaki 1995) establishes specific accuracy and precision criteria for the four quality control checks. Samples with one or more quality control results outside of the criteria are identified in Sasaki (1996a and 1996b) and Appendix A.

The precision is estimated-by the retative percent difference (RPD), -defined as the absolute value of the difference between the primary and duplicate samples, divided by their mean, times 100 . Variability in the analytical results may be caused by the very small samples (10 to $20 \mathrm{mg}$ in DSC and TGA and approximately $1 \mathrm{~g}$ in IC and ICP) used in these analyses, which imposes the need for a high degree of homogeneity in the sample to achieve reproducible results. The requisite degree of homogeneity may not have been achievable with the procedures and equipment in place at the time of analysis. Difficulties in producing 
a highly homogeneous subsample are probably responsible for most of the RPD values exceeding 20 percent. Reruns were not performed except for the DSC and gravimetric samples specified in Appendix A because the results that were out of specification were substantially below any established threshold criteria.

Preparation blanks are used to identify any sample contamination introduced in the laboratory during the process of sample breakdown, digestion, and dilution. The blank results indicated contamination was not a problem.

Quality control results are provided in Appendix A. Although some samples did have precision quality control results outside the SAP boundaries, the vast majority of the quality control results were within the boundaries specified in the SAP (Sasaki 1995). However, an evaluation of quality control discrepancies has been made, and no impact to the validity or use of the data has been found.

\subsubsection{Data Consistency Checks}

Comparing different analytical methods helps in assessing data consistency and quality. Data consistency checks included comparing phosphorus and sulfur as analyzed by ICP with phosphate and sulfate as analyzed by IC, and calculating a mass and charge balance to assess data consistency.

5.1.3.1 Comparison of Results from Different Analytical Methods. The following data consistency checks compare the results from IC and ICP analytical methods for sulfate and phosphate. Close agreement between the two methods strengthens the credibility of both results. Discrepancies between the two methods suggest that further examination of the data or the assumptions regarding the data is necessary. Table 5-1 presents the phosphate and sulfate comparisons. All segment analytical mean results were taken from Table 4-2; composite analytical results are in Appendix A.

The analytical phosphorus mean result in the saltcake, as determined by ICP analyses, was $1,010 \mu \mathrm{g} / \mathrm{g}$ which converts to $3,090 \mu \mathrm{g} / \mathrm{g}$ of phosphate (assuming that all the phosphorous is present as phosphate). This result is much lower than the IC phosphate mean result of $4,890 \mu \mathrm{g} / \mathrm{g}$. Typically, there are insoluble phosphates in the waste matrices, and the IC method does not detect them. The ICP method usually does detect them. However, because of biases in the analytical method or sample preparation procedure, discrepancies can occur. The ratio of IC to ICP results usually indicates the solubility of the phosphate. In this case, it was 158 percent which is not a reasonable value. The RPD between these two phosphate estimates was an unreasonable 45.1 percent. Because of this discrepancy, the ion chromatography results were used for the mass and charge balance, and phosphate solubility was considered 100 percent. 
Table 5-1. Comparison of Phosphate/Phosphorous and Sulfate/Sulfur Concentrations by Different Methods.

\begin{tabular}{|l|l|l|}
\hline \multicolumn{1}{|c|}{ Saltcake } \\
\hline $\mathrm{PO}_{4}{ }^{3-}(\mu \mathrm{g} / \mathrm{g})$ & \multicolumn{1}{|c|}{$\mathrm{IC}$} & \multicolumn{1}{c|}{ Solibility: } \\
\hline 3,090 & $\mathrm{PO}_{4}{ }^{3-}(\mu \mathrm{g} / \mathrm{g})$ & $(\mathrm{IC} / \mathrm{ICP})$ \\
\hline $\mathrm{SO}_{4}{ }^{2-}(\mu \mathrm{g} / \mathrm{g})$ & 4,870 & 158 percent $(100$ percent $)$ \\
\hline 9,420 & $\mathrm{SO}_{4}{ }^{2-}(\mu \mathrm{g} / \mathrm{g})$ & $(\mathrm{IC} / \mathrm{ICP})$ \\
\hline
\end{tabular}

Notes:

ICP:A = Inductively coupled plasma - acid prepared sample result

IC $=$ Ion chromatography result

The ICP sulfur value of $3,140 \mu \mathrm{g} / \mathrm{g}$ converts to $9,420 \mu \mathrm{g} / \mathrm{g}$ of sulfate (assuming all the sulfur is present as sulfate). This compares favorably with the IC sulfate result of $10,600 \mu \mathrm{g} / \mathrm{g}$. The ratio of IC to ICP results usually indicates the solubility of the sulfate. In this case, it was 112.5 percent. The RPD between the two sulfate estimates was 11.8 percent, suggesting that almost all of the sulfur/sulfate in the saltcake was soluble. In this case, the ion chromatography results provided better internal consistency and were used in the mass balance, and sulfate solubility was considered 100 percent.

5.1.3.3 Mass and Charge Balance. The principal objective in performing a mass and charge balance is to determine whether measurements are consistent. In calculating the balances, only analytes, which were detected at a concentration of $1,000 \mu \mathrm{g} / \mathrm{g}$ or greater, were considered (see Table 4-2).

Except for sodium, the cations listed in Table 5-2 were assumed to be in their most common oxide/hydroxide form. The concentrations of the assumed species were calculated stoichiometrically. Because precipitates are neutral species, all positive charge was attributed to sodium. Acetate species were assumed for the total organic carbon analysis. The other anionic analytes listed in Table 5-3 were assumed to be present as mostly sodium salts and were expected to balance the positive charge exhibited by the cations. Sulfur was present as the sulfate ion, was assumed to be completely water soluble, and appeared only in the anion mass and charge calculations (see Section 5.1.3.1). The IC phosphate value was included in the anion mass and charge data. The concentrations of the cationic species, the anionic species, and the percent water were ultimately used to calculate the mass balance. The uncertainty estimates (RSDs) associated with each analyte, and the uncertainty estimates for the cation and anion totals also are shown in the tables. 
Table 5-2. Cation Mass and Charge Data.

\begin{tabular}{|c|c|c|c|c|c|}
\hline Analyte & $\begin{array}{r}\text { Concentration } \\
(\mu \mathrm{g} / \mathrm{g})\end{array}$ & $\begin{array}{r}\text { RSD } \\
\text { (Mean) } \\
\text { (percent) }\end{array}$ & $\begin{array}{l}\text { Assumed } \\
\text { Species }\end{array}$ & $\begin{array}{l}\text { Concentration of } \\
\text { Assumed Species } \\
\text { (ug/g) : }\end{array}$ & $\begin{array}{l}\text { Charge } \\
(\mu \text { eq/g) }\end{array}$ \\
\hline Aluminum & 18,400 & 19.9 & $\mathrm{Al}(\mathrm{OH})_{3}$ & 53,000 & 0 \\
\hline Sodium & 198,000 & 2.69 & $\mathrm{Na}^{+}$ & 198,000 & 8,609 \\
\hline Total & & & & 251,000 & 8,609 \\
\hline
\end{tabular}

Table 5-3. Anion Mass and Charge Data.

\begin{tabular}{|c|c|c|c|}
\hline Analyte & $\begin{array}{l}\text { Concentration } \\
(4 \mathrm{~g})\end{array}$ & $\begin{array}{l}\text { RSD (Mean) } \\
\text { (percent) }\end{array}$ & $\begin{array}{l}\text { Charge } \\
(\text { (reg/g) }\end{array}$ \\
\hline Acetate (TOC) & 16,300 & 36.0 & -275 \\
\hline Fluoride & 4,100 & 29.6 & -216 \\
\hline Nitrate & 491,000 & 15.8 & $-7,919$ \\
\hline Nitrite & 9,410 & 14.4 & -205 \\
\hline Oxalate & 11,300 & 41.9 & -128 \\
\hline Phosphate & 4,890 & 46.8 & -154 \\
\hline Sulfate & 10,600 & 36.2 & -221 \\
\hline Totals & 548,000 & & $-9,118$ \\
\hline
\end{tabular}

The mass balance was calculated from the formula below. The factor 0.0001 is the conversion factor from $\mu \mathrm{g} / \mathrm{g}$ to weight percent.

Mass balance $=\%$ water $+0.0001 \times$ \{total analyte concentration $\}$ $=\%$ water $+0.0001 \times\left\{\mathrm{Al}(\mathrm{OH})_{3}+\mathrm{Na}^{+}+\mathrm{C}_{2} \mathrm{H}_{3} \mathrm{O}_{2}^{-}+\mathrm{F}^{-}+\mathrm{NO}_{3}^{-}+\mathrm{NO}_{2}^{-}+(\mathrm{COO})_{2}^{-2}+\right.$ $\left.\mathrm{PO}_{4}^{-3}+\mathrm{SO}_{4}^{-2}\right\}$

The total analyte concentrations calculated from the above equation was $799,000 \mu \mathrm{g} / \mathrm{g}$. The mean weight percent water obtained from thermogravimetric analysis was 16.1 percent (see Table 4-2). The mass balance resulting from adding the percent water to the total analyte concentration is 96 percent (see Table 5-4). Using propagation of error techniques, the RSD of the mass balance is approximately nine percent. 
Table 5-4. Mass Balance Totals.

\begin{tabular}{|c|c|c|}
\hline יר: & $\begin{array}{l}\text { Concemtrations } \\
(\text { gg/g) }\end{array}$ & $\begin{array}{l}\text { Charge } \\
\text { (reatg) }\end{array}$ \\
\hline Total from Table 5-3 (cations) & 251,000 & 8,609 \\
\hline Total from Table 5-4 (anions) & 548,000 & $-9,118$ \\
\hline Water percent & 16.1 & 0 \\
\hline Grand Total & 960,000 & -509 \\
\hline
\end{tabular}

The following equations demonstrate the derivation of total cations and total anions; the charge balance is the ratio of these two values.

Total cations (microequivalents) $=\mathrm{Na}^{+} / 23.0=8,609$ microequivalents

Total anions (microequivalents) $=\mathrm{C}_{2} \mathrm{H}_{3} \mathrm{O}_{2}^{-} / 59.0+\mathrm{F}^{-/ 19.0}+\mathrm{NO}_{3}^{-1 / 62.0}+\mathrm{NO}_{2}^{-1 / 46.0}+$ $(\mathrm{COO})_{2}{ }^{-2} / 44.0+\mathrm{PO}_{4}^{-3 / 31.7}+\mathrm{SO}_{4}^{-2 / 48.1}=$ $-9,118$ microequivalents

The charge balance was 94 percent. It was obtained by dividing the sum of the positive charge by the sum of the negative charge and taking the absolute value. The net negative charge was 509 microequivalents. Using propagation of error techniques, the RSD for total cations is approximately three percent and for total anions is approximately 14 percent. The RSD for the charge balance is also approximately 14 percent. Perfect agreement is $1,000,000 \mu \mathrm{g} / \mathrm{g}$ for the mass balance and 1.00 for the charge balance with no net charge remaining.

In summary, these calculations yield a reasonable mass balance and charge balance ( 96 percent for mass balance and 94 percent for charge balance). The principal components of the samples obtained appear to be sodium nitrate and water.

\subsection{COMPARISON OF 1995 CORE SAMPLE and GRAB SAMPLE RESULTS}

Table 5-5 compares drainable liquid results for the September 1995 core sample event with grab sample results obtained in March 1995. The RPD between the two samples is below 50 percent except for nitrite and fluoride (54 percent) and aluminum (122 percent). 


\subsection{TANK WASTE PROFILE}

One objective of the 1995 sampling event was to obtain a vertical profile of the waste from two or more widely-spaced risers (Sasaki 1995). Only one partial vertical profile was obtained from riser 5. As a result discussion in this section is limited to a comparison of results for the top 3 segments of core 108. Historical estimates of tank contents and tank profile information are available in Agnew et al. (1996) and summarized in Section 3.0 of this report. According to the TLM, the waste in the tank is composed of three layers: a heel of MW waste with PFeCN2 waste on the bottom third of the tank, and BY saltcake in the upper two-thirds. Portland cement is expected to be mixed in with the BY saltcake. Sample analyses to this point appear to be consistent with Agnew et al. (1996) for the top portion of the tank. However, elevated calcium concentrations were not observed in any sample as would be expected if Portland cement was present. The hard layer encountered when attempting to obtain segment 3 may be Portland cement. It is about the right depth in the tank as expected from the 1966 transfer date. Additional core samples are required to verify this to describe the tank profile in greater detail.

Table 5-5. Comparison of 1995 core sample and grab sample results. ${ }^{1}$

\begin{tabular}{|c|c|c|c|}
\hline Analyte: & $\begin{array}{l}\text { Sept, } 1995 \\
\text { Drainable Liquid }\end{array}$ & $\begin{array}{l}\text { March } 1995 \\
\text { Grab Sample }\end{array}$ & RPI) \\
\hline Percent water & 50.2 & 55.7 & 10.4 \\
\hline Specific gravity & 1.43 & 1.23 & 15.0 \\
\hline Aluminum $(\mu \mathrm{g} / \mathrm{mL})$ & 25,400 & 6,128 & 122 \\
\hline Iron $(\mu \mathrm{g} / \mathrm{mL})$ & $<$ detection limit & $\mathrm{nm}$ & $\mathrm{nm}$ \\
\hline Sodium $(\mu \mathrm{g} / \mathrm{mL})$ & 203,000 & 183,500 & 9.36 \\
\hline Sulfate $(\mu \mathrm{g} / \mathrm{mL})$ & 1,680 & $\mathrm{~nm}$ & $\mathrm{~nm}$ \\
\hline Phosphate $(\mu \mathrm{g} / \mathrm{mL})$ & 894 & $n m$ & $\mathrm{~nm}$ \\
\hline Nitrate $(\mu \mathrm{g} / \mathrm{mL})$ & 220,000 & 298,000 & 30.1 \\
\hline Nitrite $(\mu \mathrm{g} / \mathrm{mL})$ & 44,900 & 26,600 & 54.2 \\
\hline Fluoride $(\mu \mathrm{g} / \mathrm{mL})$ & 534 & 805 & 40.5 \\
\hline Chloride $(\mu \mathrm{g} / \mathrm{mL})$ & 3,660 & 2,100 & 54.2 \\
\hline TOC $(\mu \mathrm{g} / \mathrm{mL})$ & 2,090 & 1,665 & 22.6 \\
\hline
\end{tabular}

Notes:

$\mathrm{nm}=$ not measured

${ }^{1}$ Esch (1995) Sasaki (1996a) 


\subsection{COMPARISON OF ANALYTICAL AND TRANSFER DATA}

Although additional samples were not taken or analyzed for the historical $D Q O$, some comparisons can be made with the data obtained. The key fingerprint analytes identified in the historical DQO (Simpson and McCain 1995) for tank BY-105 include the following: sodium, aluminum, nitrate, sulfate, and percent water. Tank BY-105 was selected for historical evaluation because it was expected to contain a thick saltcake layer and a thick ferrocyanide waste layer (Agnew et al. 1996). The first step in the evaluation was to compare the analytical results with DQO-defined concentration levels for the "fingerprint" analytes. This comparison ensures that a predicted waste type is in the tank at the predicted location within the waste matrix. If the analytical results are $\geq 10$ percent of the DQO levels (ratio of 0.1 ), the waste type and layer identification are further investigated (Simpson and McCain 1995). BY saltcake was predicted to comprise the top two-thirds of the tank waste (Agnew et al. 1995a). Therefore, a comparison was made between the mean results for each top three sampled segments from core 108 and fingerprint analyte concentrations for saltcake (see Table 5-6).

Table 5-6. Comparison of BY Saltcake Fingerprint Analytes with Analytical Results.

\begin{tabular}{|l|l|l|}
\hline Tingerprint Analyte: & Mean Analytical Resulits & \multicolumn{1}{|c|}{ CIistorical DogO } \\
\hline Sodium & $198,000 \mu \mathrm{g} / \mathrm{g}$ & $>165,000 \mu \mathrm{g} / \mathrm{g}$ \\
\hline Aluminum & $18,400 \mu \mathrm{g} / \mathrm{g}$ & $18,600 \mu \mathrm{g} / \mathrm{g}$ \\
\hline Nitrate & $491,000 \mu \mathrm{g} / \mathrm{g}$ & $>266,000 \mu \mathrm{g} / \mathrm{g}$ \\
\hline Sulfate & $10,600 \mu \mathrm{g} / \mathrm{g}$ & $33,700 \mu \mathrm{g} / \mathrm{g}$ \\
\hline Percent water & $16.1 \%$ & $35.9 \%$ \\
\hline
\end{tabular}

Note:

'Simpson and McCain (1995)

All of the mean analytical results for the fingerprint analytes were at concentrations greater than 10 percent of the historical DQO concentration level for those analytes. Consequently, this waste type appears to fit the description of BY saltcake. However, because the samples did not meet the DQO requirement for completeness, additional comparisons were not done.

\subsection{SAFETY EVALUATION}

Data criteria identified in the safety screening DQO (Dukelow et al. 1995) were used to assess the waste safety and to check for unidentified safety issues. The DQO requires samples from two widely spaced risers. This requirement was not met because sampling was terminated early: the waste was too hard to push through and rotary drilling was halted by 
potential flammability concerns. The three primary analyses required by the safety screening DQO included the following: DSC to evaluate energetics, TGA to measure weight percent water, and a determination of total alpha activity. For each required analysis, the DQO notification limit was established which, if exceeded, could warrant further investigation to ensure tank safety. A final requirement of the safety screening DQO was to determine the flammability of tank headspace vapors. These measurements were taken prior to removing core samples. Tank flammable vapors were measured at 0.2 percent of the LFL, well below the safety screening limit of 25 percent (Dukelow et al. 1995). To compare tank 241-BY-105 observations and relevant vapor thresholds, see Table 4-4.

The safety screening DQO limit for criticality is $33.1 \mu \mathrm{Ci} / \mathrm{g}$. It was assessed from the total alpha activity. All results obtained were well below this limit; the largest single result was $0.31 \mu \mathrm{Ci} / \mathrm{g}$ with the upper limit to a one-sided 95 percent confidence interval on the mean being $0.43 \mu \mathrm{Ci} / \mathrm{g}$.

The safety screening DQO has established a notification limit of $-480 \mathrm{~J} / \mathrm{g}$ (dry weight basis) for the DSC analysis. Two samples exceeded this limit with dry weight exotherms of $-1,465 \mathrm{~J} / \mathrm{g}$ for sample $595 \mathrm{~T} 003418$ (drainable liquid, segment $1 \mathrm{AR}$ ) and $-806 \mathrm{~J} / \mathrm{g}$ for sample S95T003399 (solid, segment 3). The upper limits of the 95 percent confidence intervals for these samples were $-1,895 \mathrm{~J} / \mathrm{g}$ and $-1,053 \mathrm{~J} / \mathrm{g}$, respectively.

The total organic carbon content notification limit was set at $30,000 \mu \mathrm{g} / \mathrm{g}$. A mean TOC concentration of $3,870 \mu \mathrm{g} \mathrm{C} / \mathrm{g}$ (dry) was found in the saltcake. No sample exceeded the notification limit. No sample with a separable organic layer was observed.

To investigate the relationship between the DSC results and the TOC and cyanide concentrations, the DSC dry weight results for those subsegments, which had exothermic reactions greater than the $-480 \mathrm{~J} / \mathrm{g}$ threshold limit, are compared with the corresponding dry weight TOC and cyanide results and their energy equivalents in Table 5-7. The TOC data were converted to their energy equivalents using the following equation. The $632 \mathrm{~J} / \mathrm{g}$ value represents the energy equivalent of 5 weight percent TOC, based on a sodium acetate average energetics standard. Drainable liquid values were converted from $\mu \mathrm{g} / \mathrm{mL}$ to $\mu \mathrm{g} / \mathrm{g}$ by dividing by the average specific gravity $(1.4 \mathrm{~g} / \mathrm{mL})$. The TOC analytical results were converted from $\mu \mathrm{g} / \mathrm{g}$ to weight percent by dividing by 10,000 .

$$
\text { Energy Equivalent }=w t \% \operatorname{TOC}(\text { dry weight }) \frac{(632 \mathrm{~J} / \mathrm{g})}{5}
$$


Table 5-7. Comparison of DSC Analytical Results Exceeding the Threshold Limit with TOC and Cyanide Results.

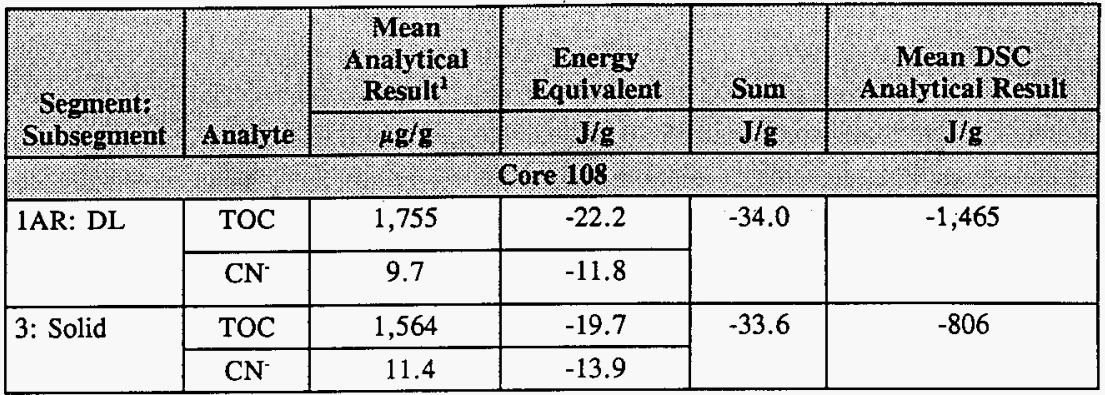

Notes:

'Dry weight basis.

The cyanide fuel content was assumed to exist as the species $\mathrm{Na}_{2} \mathrm{NiFe}(\mathrm{CN})_{6}$ (Meacham et al. 1995). The necessary conversion of the cyanide analytical result (dry weight) to the weight percent of the assumed species was accomplished by the following equation:

$$
\begin{aligned}
& \mathrm{Na}_{2} \mathrm{NiFe}(\mathrm{CN})_{6} w t \%=\left[\frac{X \mu g \mathrm{CN}}{g}\right) *\left(\frac{1 \mu \mathrm{mol} \mathrm{CN}}{26 \mu g \mathrm{CN}}\right) *\left(\frac{1 \mu \mathrm{mol} \mathrm{Na} \mathrm{NiFe}(\mathrm{CN})_{6}}{6 \mu \mathrm{mol} \mathrm{CN}}\right) * \\
& \left(\frac{316.5 \mu \mathrm{g} \mathrm{Na} a_{2} \mathrm{NiFe}(\mathrm{CN})_{6}}{1 \mu \mathrm{mol} \mathrm{Na} a_{2} \mathrm{NiFe}(\mathrm{CN})_{6}}\right) *\left(\frac{1}{1 \times 10 \mathrm{SUP} \mathrm{mug}}\right) * 100 w t \% \mathrm{Na}_{2} \mathrm{NiFe}(\mathrm{CN})_{6}
\end{aligned}
$$

The resulting weight percent was then inserted into the energy equivalent ferrocyanide concentration equation given in Meacham et al. (1995), which was manipulated algebraically to give the following energy equivalent in $\mathrm{J} / \mathrm{g}$ :

$$
\text { (weight\% } \left.\mathrm{Na}_{2} \mathrm{NiFe}(\mathrm{CN})_{6}\right) *\left(\frac{6,000 \mathrm{~J} / \mathrm{g} \mathrm{Na} \mathrm{NiFe}(\mathrm{CN})_{6}}{100 \text { weight\% }}\right)=X \mathrm{~J} / \mathrm{g} \text { waste }
$$

For a given subsegment, the energy equivalent values for cyanide and TOC were added in column 5 of Table 5-7; the mean DSC analytical result is in column 6. The sum of the two energy equivalents were well below the DSC results. Assuming that all of the TOC is present as sodium acetate may have biased the comparison slightly, but it would probably not 
account for the differences observed. Although some exothermic activity was observed, the fuel content estimates based on the TOC and cyanide results observed indicate that excessive fuel sources are not present, and the exotherms are not a safety problem.

Another factor in assessing tank waste safety is heat generation and waste temperature. Heat is generated in the tanks by radioactive decay. The estimated tank head load of $2.46 \mathrm{~kW}$ $(8,400 \mathrm{Btu} / \mathrm{hr}$ ) (Agnew et al. 1996) and $2.55 \mathrm{~kW}(8,700 \mathrm{Btu} / \mathrm{hr}$ ) (Kummerer 1995) were well below the $11.7 \mathrm{~kW}$ limit that separates high-heat and low-heat load tanks (Bergmann 1991). The heat load could not be calculated from the 1995 analytical data because radionuclide analyses were not performed. However, the low levels of alpha activity in the tank and the continuous trend of decreasing tank temperatures since 1993 indicate that exothermic reactions are unlikely. 


\subsection{CONCLUSIONS AND RECOMMENDATIONS}

The waste in tank 241-BY-105 was sampled and analyzed during August to October of 1995 for the purposes of safety screening in accordance with the requirements listed in the following documents: Tank Safety Screening Data Quality Objective (Dukelow et al. 1995), the Data Requirements for the Ferrocyanide Safety Issue Developed through the Data Quality Objectives Process (Meacham et al. 1994), Data Quality Objective to Support Resolution of the Organic Complexant Safery Issue (Turner et al. 1995), Test Plan for Samples From Hanford Waste Tanks 241-BY-103, BY-104, BY-105, BY-108, BY-110, TY-103, U-105, U-107, U-108, and U-109 (Meacham 1995), Historical Model Evaluation Data Requirements (Simpson and McCain 1995), and Strategy for Sampling Hanford Site Tank Wastes for Development of Disposal Technology (Kupfer et al. 1995). Grab Sampling was completed in March 1995 to satisfy the requirements of Data Quality and Objectives for the Waste Compatibility Program (Fowler 1995).

However, as a result of sampling difficulties, samples were obtained from only part of one core. As a result the only DQO that was fully met was the compatibility DQO, which was met by the March 1995 grab sampling event. The September core analyses were conducted for the safety screening and TOC DQOs. The IC and ICP analyses were obtained to assess hydrostatic head fluid intrusion. The IC/ICP values were used for mass balance calculations and to compare gateway historical estimates of tank waste composition.

Analytical results showed that the waste contains some compounds capable of exothermic reactions. Two samples demonstrated exotherms with enthalpy changes in excess of the $-480 \mathrm{~J} / \mathrm{g}$ safety screening limit. One sample had a water content of 7.2 percent. However, TOC and cyanide comparisons with DSC results indicated that this was not a safety concern. The ICP analyses showed that the only metals found at concentrations of one weight percent or greater were aluminum and sodium. Anions detected at concentrations than one weight percent included nitrate, sulfate, and oxalate.

Total alpha activity was approximately 0.1 percent of the safety screening limit. Total organic carbon and cyanide concentrations, required by Meacham et al. (1994), were well below their respective notification limits.

The estimated tank heat load of between 2.46 to $2.55 \mathrm{~kW}(8,390$ to $8,700 \mathrm{Btu} / \mathrm{hr})$ was well below the $11.7 \mathrm{~kW}(40,000 \mathrm{Btu} / \mathrm{hr})$ limit that separates high-heat and low-heat load tanks. The highest LFL measured from the tank headspace was less than 1 percent, which is significantly lower than the 25 percent limit (Dukelow et al. 1995).

The available analytical data suggests that the BY saltcake in this tank is principally sodium nitrate. The measurements appear to be consistent, meaning that no additional assumptions about the composition of these samples were necessary to complete the mass and charge 
balance performed. The samples from this core sample event pass the gateway analysis for historical assessment. However, the current data set does not support further analysis as described in the historical DQO.

In summary, the limited analytical results from the 1995 rotary core sampling indicate that the top portion of tank $241-\mathrm{BY}-105$ is safe when compared to the safety screening data quality objectives (Sasaki 1996b). Although some exothermic activity was observed, the fuel content estimates based on the TOC and cyanide results that excessive fuel sources are not present and this is not a safety concern. The tank heat load estimate given by Agnew et al. (1996) and head space flammability measurements were both well below established limits. However, additional rotary core samples of the full tank profile are required to more conclusively assess tank safety and meet the requirements of the applicable DQOs. 


\subsection{REFERENCES}

Adams, M. K., 1996, Tank Characterization Project Data Management Plan, WHC-SD-WM-MP-002, Rev. 0, Westinghouse Hanford Company, Richland, Washington.

Agnew, S. F., J. Boyer, R. A. Corbin, T. B. Duran, J. R. Fitzpatrick, K. A. Jurgensen, T. P. Ortiz, and B. L. Young, 1996, Hanford Tank Chemical and Radionuclide Inventories, HDW Model Rev. 3, LA-UR-96-858, Rev. 0, Los Alamos National Laboratory, Los Alamos, New Mexico.

Agnew, S. F., P. Baca, R. Corbin, K. Jurgensen, and B. Young, 1995a, Tank Layer Model for Northeast, Southwest, and Northwest Quadrants, LAUR-94-4269, Rev. 1, Los Alamos National Laboratory, Los Alamos, New Mexico.

Agnew, S. F., P. Baca, R. Corbin, T. Duran, and K. Jurgensen, 1995b, Waste Status and Transaction Record Summary for the Northeast Quadrant, WHC-SD-WM-TI-615, Rev. 2, Westinghouse Hanford Company, Richland, Washington.

Alstad, A. T., 1993, Riser Configuration Document for Single-Shell Waste Tanks, WHC-SD-RE-TI-053, Rev. 9, Westinghouse Hanford Company, Richland, Washington.

Bechtold, D. B., 1996 "RSST Adiabatic Calorimetry Results of BY-105 Samples," (Internal Memo 75764-PC596-079, to L. M. Sasaki, August 5, 1996), Westinghouse Hanford Company, Richland, Washington.

Bechtold, D. B., 1992, Laboratory Test Plan for Adiabatic Calorimetry of Single-Shell and Double-Shell Tank Wastes, WHC-SD-WM-TP-104, Rev. 0, Westinghouse Hanford Company, Richland, Washington.

Bergmann, L. M., 1991, Single-Shell Tank Isolation Safery Analysis Report, WHC-SD-WM-SAR-006, Rev. 2, Westinghouse Hanford Company, Richland, Washington.

Brevick, C. H., L. A. Gaddis, and W. W. Pickett, 1995, Historical Tank Content Estimate for the Northeast Quadrant of the Hanford 200 East Area, WHC-SD-WM-ER-349, Rev. 0-A, Westinghouse Hanford Company, Richland, Washington.

Brevick, C. H., L. A. Gaddis, and A. C. Walsh, 1994, Supporting Document for the Northeast Quadrant Historical Tank Contents Estimate Report for BY-Tank Farm, WHC-SD-WM-ER-312, Rev. 0, Westinghouse Hanford Company, Richland, Washington. 
DeLorenzo, D. J., A. T. DiCenso, D. B. Hiller, K. W. Johnson, J. H. Rutherford, B. C. Simpson, and D. J. Smith, 1994, Tank Characterization Reference Guide, WHC-SD-WM-TI-648, Rev. 0, Westinghouse Hanford Company, Richland, Washington.

Dukelow, G. T., J. W. Hunt, H. Babad, and J. E. Meacham, 1995, Tank Safety Screening Data Quality Objective, WHC-SD-WM-SP-004 Rev. 2, Westinghouse Hanford Company, Richland, Washington.

DOE, 1995, Hanford Analytical Services Quality Assurance Plan, DOE/RL-94-55, Rev. 2, U.S. Department of Energy, Richland, Washington.

Ecology, EPA, and DOE, 1996, Hanford Federal Facility Agreement and Consent Order, as amended, Washington State Department of Ecology, U.S. Environmental Protection Agency, and U.S. Department of Energy, Olympia, Washington.

Esch, R. A., 1995, "Results for 241-BY-105 Grab Samples," (Internal Memo 8E480-95-020, to J. M. Jones, April, 6 1995), Westinghouse Hanford Company, Richland, Washington.

Farley, W. G., 1991, Safety Assessment for Gas Sampling All Ferrocyanide Tanks, WHC-SD-WM-SAD-009 Rev. 2, Westinghouse Hanford Company, Richland, Washington.

Fowler, K. D., 1995, Data Quality Objectives for Tank Farms Waste Compatibility Program, WHC-SD-WM-DQO-001, Rev. 1, Westinghouse Hanford Company, Richland, Washington.

Grigsby, J. M., D. B. Bechtold, G. L. Borsheim, M. D. Crippen, D. R. Dickinson, G. L. Fox, D. W. Jeppson, M. Kummerer, J. M. Mclaren, J. D. McCormack, A. Padilla, B. C. Simpson, D. D. Stepnewski, 1992, Ferrocyanide Waste Tank Hazard Assessment--Interim Report, WHC-SD-WM-RPT-032, Rev. 1, Westinghouse Hanford Company, Richland, Washington.

Hanlon, B. M., 1996, Waste Tank Summary Report for Month Ending February 29, 1996, WHC-EP-0182-95, Westinghouse Hanford Company, Richland, Washington.

Hartley, S. A., K. M. Remund, B. C. Simpson, R. D. Cromar, and C. M. Amderson, 1995, Statistical Supplement to he Tark Characterization Reference Guide, WHC-SD-WM-TI-648, Rev. 0, Westinghouse Hanford Company, Richland, Washington.

Hodgson, K. M., 1995, "Portland Cement in Tank 241-BY-105, (Internal memo 71330-95004 to N. W. Kirch, March 29, 1995), Westinghouse Hanford Company, Richland, Washington. 
Huckaby, J. L. and D. R. Bratzel, 1995, Tank 241-BY-105 Headspace Gas and Vapor Characterization Results for Samples Collected in May 1994 and July 1994, WHC-SD-WM-ER-419, Rev. 2A, Westinghouse Hanford Company, Richland, Washington.

Huckaby, J. L., H. Babad, and D. R. Bratzel, 1995, Headspace Gas and Vapor Characterization Summary for the 43 Vapor Program Suspect Tanks, WHC-SD-WM-ER-514 Rev. 0, Westinghouse Hanford Company, Richland, Washington.

Huckaby, J. L., 1994, Vapor Sampling System (VSS) and In Situ Sampling (ISS) Method Comparison, WHC-SD-WM-RPT-101 Rev. 0, Westinghouse Hanford Company, Richland, Washington.

Huckaby, J. L., and M. S. Story, 1994, Vapor Characterization of Tank 241-C-103, WHC-EP-0780 Rev. 0, Westinghouse Hanford Company, Richland, Washington.

Kristofzski, J. G., 1995, "Directions for Opportunistic Analyses," (Letter 75310-95-103 to J. H. Baldwin, September 13), Westinghouse Hanford Company, Richland, Washington.

Kummerer, M. 1994, Topical Report on Heat Removal Characteristics of Waste Storage Tanks, WHC-SD-WM-SARR-010, Rev. 0, Westinghouse Hanford Company, Richland, Washington.

Kupfer, M. J., W. W. Schulz, and J. T. Slankas, 1995, Strategy for Sampling Hanford Site Tank Wastes for Development of Disposal Technology, WHC-SD-WM-TA-154, Rev. 1, Westinghouse Hanford Company, Richland, Washington.

Leach, C. E., and S. M. Stahl, 1993, Hanford Site Tank Farm Facilities Interim Safety Basis, WHC-SD-WM-ISB-001, Rev. 0, Westinghouse Hanford Company, Richland, Washington.

Lipnicki, J., 1996, Waste Tank Risers Available for Sampling, WHC-SD-WM-TI-710, Rev. 2, Westinghouse Hanford Company, Richland, Washington.

Meacham, J. E., 1995, Test Plan for Samples From Hanford Waste Tanks 241-BY-103, $B Y-104, B Y-105, B Y-106, B Y-108, B Y-110, T Y-103, U-105, U-107, U-108$, and $U$-109, WHC-SD-WM-TP-378, Rev. 0A, Westinghouse Hanford Company, Richland, Washington. 
Meacham, J. E., C. M. Anderson, H. Babad, J. W. Buck, R. J. Cash, G. T. Dukelow, B. A. Pulsipher, J. J. Toth, and P. J. Turner, 1994, Data Requirements for the Ferrocyanide Safety Issue Developed through the Data Quality Objectives Process, WHC-SD-WM-DQO-007, Rev. 0, Westinghouse Hanford Company, Richland, Washington.

Osborne, J. W., J. L. Huckaby, E. R. Hewitt, C. M. Anderson, D. D. Mahlum, B. A. Pulsipher, J. Y. Young, 1994, Data Quality Objectives for Generic In-Tank Health and Safery Vapor Issue Resolution, Westinghouse Hanford_Company, Richland, Washington.

Osborne, J. W., and J. L. Huckaby, 1994, Program Plan for the Resolution of Tank Vapor Issues, WHC-EP-0562 Rev. 1, Westinghouse Hanford Company, Richland, Washington.

Rodenhizer, D. G., 1987, Hanford Waste Tank Sluicing History, WHC-SD-WM-TI-302, Westinghouse Hanford Company, Richland, Washington.

Sasaki, L. M., 1995, Tank 241-BY-105 Rotary Core Sampling and Analysis Plan, WHC-SD-WM-TSAP-046 Rev. 0-A, Westinghouse Hanford Company, Richland, Washington.

Sasaki, L. M., 1996a, Final Report for Tank 241-BY-105 Rotary and Push Mode Samples, Core 108, WHC-SD-WM-DP-162 Rev. 1, Westinghouse Hanford Company, Richland, Washington.

Sasaki, L. M., 1996b, 45 Day Safety Screening Results for Tank 241-BY-105 Rotary and Push Mode Samples, Core 108, WHC-SD-WM-DP-162, Rev. 0, Westinghouse Hanford Company, Richland, Washington.

Schreiber, R. D., 1995, Tank 241-BY-105 Tank Characterization Plan, WHC-SD-WM-TP-218, Rev. 1, Westinghouse Hanford Company, Richland, Washington.

Simpson, B. C., and D. J. McCain, 1995, Historical Model Evaluation Data Requirements, WHC-SD-WM-DQO-018, Rev. 0-A, Westinghouse Hanford Company, Richland, Washington.

Swaney, S. L., 1993 "Waste Level Discrepancies Between Manual Level Readings and Current Waste Inventory for Single-Shell Tanks," (Internal memo 7C242-93-038 to G. T. Frater, December 10, 1993, Westinghouse Hanford Company, Richland, Washington. 
Tran, T. T., 1993, Thermocouple Sratus Single-Shell and Double-Shell Waste Tanks, WHC-SD-WM-TI-533, Rev. 0, Westinghouse Hanford Company, Richland, Washington.

Turner, D. A., H. Babad, L. L. Buckley, and J. E. Meacham, 1995, Data Quality Objective to Support Resolution of the Organic Complexant Safety Issue, WHC-SD-WM-DQO-006, Rev. 2, Westinghouse Hanford Company, Richland, Washington.

Winkelman, W. D., 1996, Technical Basis and Spreadsheet Documentation for Correcting Waste Tank Core Samples for Water Intrusion Based on a LiBr Tracer, WHC-SD-WM-CSWD-081, Rev. 0, Westinghouse Hanford Company, Richland, Washington.

WHC, 1995a, Operating Specification for Watch List Tanks, OSD-T-151-00030, Rev/Mod. B-9, Westinghouse Hanford Company, Richland, Washington.

WHC, 1995b, Tank Waste Remediation System Fiscal Year 1996 Multi-Year Program Plan, W.B.S. 1.1, WHC-SP-1101, Rev. 1a, Westinghouse Hanford Company, Richland, Washington.

WHC, 1992, Fire Protection Engineering Surveys Instructions, WHC-IP-0030, Westinghouse Hanford Company, Richland, Washington.

WHC, 1988, Piping and Waste Isolation Drawing, 241-BY-105, H-2-73247, Rev. 5, Westinghouse Hanford Company, Richland, Washington.

WHC, 1987, Piping Thermocouple Tree Drawing, H-2-90342, Rev. 2, sheet 2, Westinghouse Hanford Company, Richland, Washington.

WHC, 1976, 105-BY Tank Arrangement, As-Built Drawing, H-2-37105, Rev. 0, Rev. 0, Westinghouse Hanford Company, Richland, Washington. 
WHC-SD-WM-ER-598 Rev. 0

This page intentionally left blank. 
WHC-SD-WM-ER-598 Rev. 0

APPENDIX A

ANALYTICAL RESULTS FROM 1995 CORE SAMPLING 
WHC-SD-WM-ER-598 Rev. 0

This page intentionally left blank. 


\section{A.0 ANALYTICAL RESULTS FROM 1995 CORE SAMPLING}

\section{A.1 INTRODUCTION}

Appendix A reports the chemical, radiochemical, and physical characteristics of tank 241-BY-105 in terms of the specific concentrations of metals, ions, radionuclides, and physical properties.

Each data table in the appendix lists the following: laboratory sample identification, sample origin (core/segment/subsegment), an original and duplicate result for each sample, a sample mean, a mean result for the tank, an RSD (mean), and a projected tank inventory for the particular analyte using the weighted mean and the appropriate conversion factors. Projected tank inventory is not applicable to the percent water, DSC, or density data. The data are listed in standard notation for values greater than 0.001 and less than 100,000 . Values outside these limits are listed in scientific notation.

Tables are numbered A-1 through A-49. A description of the units and symbols used in the analyte tables and the references used in compiling the analytical data are found in the List of Terms and Section 7.0, respectively. See Section 3.0 for a description of the sampling event and information on sampling rationale and locations.

\section{A.2 ANALYTE TABLE DESCRIPTION}

The "Sample Number" column lists the laboratory sample for which the analyte was measured.

The "Core:Segment" column specifies the core and segment from which each sample was derived.

The "Subsegment" column specifies "Whole" or "DL," depending on whether the sample analyzed was a whole (solid) segment or drainable liquid from a segment.

The "Result" and "Duplicate" columns are self-explanatory. The "Sample Mean" column lists the average of the result and duplicate values. If the result and duplicate values were both detected, or one of the two values is detected and the other nondetected, then the mean is expressed as the detected value. If the result and duplicate values were both nondetected, then the mean is expressed as a nondetected number. The result and duplicate values and the result/duplicate means are reported in the tables exactly as found in the original laboratory data package.

The overall (or analyte concentration) means for the waste in tank 241-BY-105 were calculated using restricted maximum likelihood estimates (REML). Overall means were an average of the three segment means. 
All values, including those below the detection level (indicated by the less-than symbol, " $<$ "), were used in calculating the overall means. If 50 percent or more of all individual sample primary and duplicate results were detected, then the overall mean was expressed as a detected value. If less than 50 percent of all individual results were detected, then the overall mean was expressed as a nondetected value.

The RSD (mean) was computed for applicable analytes using standard ANOVA statistical techniques. Relative standard deviations (of the mean) were calculated for all analytes with "detected" means.

Projected inventories were not calculated for the solids portion of the waste because the samples were only obtained from the top 3 segments of the waste. Projected inventories were not calculated for the drainable liquid samples because the tank contains no supernatant (Hanlon 1996).

The four quality control parameters assessed on the tank 241-BY-105 samples were standard recoveries, spike recoveries, duplicate analyses (RPDs), and blanks. These were summarized in Section 5.1.2. More specific information is provided in the following appendix tables. Sample and duplicate pairs in which any of the quality control (QC) parameters were outside their specified limits are superscripted in the "Sample Mean" column as follows:

QC:a -- indicates that the standard recovery was below the QC range.

$\mathrm{QC}: \mathrm{b}$-- indicates that the standard recovery was above the QC range.

$\mathrm{QC}: \mathrm{c}$-- indicates that the spike recovery was below the QC range.

$\mathrm{QC}: \mathrm{d}$-- indicates that the spike recovery was above the QC range.

QC:e -- indicates that the RPD was greater than the QC limit range.

$\mathrm{QC}: \mathrm{f}$-. indicates blank contamination. 
Table A-1. Tank 241-BY-105 Analytical Results: Aluminum.

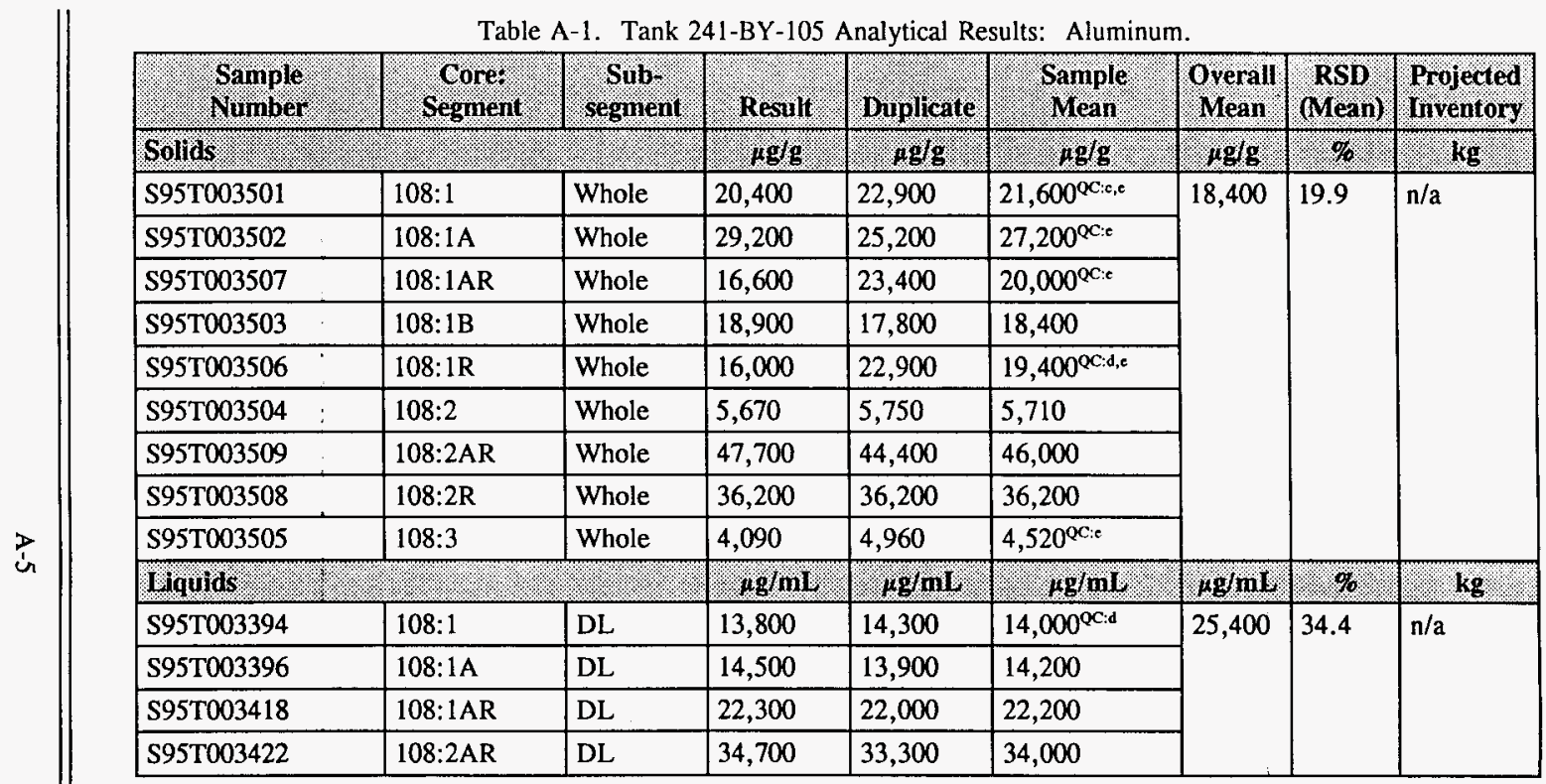


Table A-2. Tank 241-BY-105 Analytical Results: Antimony.

\begin{tabular}{|c|c|c|c|c|c|c|c|c|}
\hline $\begin{array}{l}\text { Sample } \\
\text { Number }\end{array}$ & Segrinent & Sub- & Resull & Duplicate & $\begin{array}{l}\text { Sample } \\
\text { Mean }\end{array}$ & $\begin{array}{l}\text { Overall } \\
\text { Mean }\end{array}$ & $\begin{array}{c}\text { RSD } \\
\text { (Mean) }\end{array}$ & $\begin{array}{l}\text { Projected } \\
\text { Irventory }\end{array}$ \\
\hline Solids & & & cgs & $\mu g / g$ & ig/g/ & $\alpha g / g$ & $\%$ & $\mathrm{~kg}$ \\
\hline S95T003501 & 108:1 & Whole & $<25.90$ & $<23.5$ & $<24.7$ & \multirow[t]{9}{*}{$<24.1$} & \multirow[t]{9}{*}{$n / a$} & \multirow[t]{9}{*}{$\mathrm{n} / \mathrm{a}$} \\
\hline S95T003502 & 108:1A & Whole & $<23.10$ & $<23.3$ & $<23.2$ & & & \\
\hline S95T003507 & 108:1AR & Whole & $<28.00$ & $<27.1$ & $<27.6$ & & & \\
\hline S95T003503 & 108:1B & Whole & $<22.00$ & $<21.4$ & $<21.7$ & & & \\
\hline S95T003506 & 108:1R & Whole & $<21.50$ & $<21.2$ & $<21.4$ & & & \\
\hline S95T003504 & $108: 2$ & Whole & $<26.60$ & $<28.2$ & $<27.4$ & & & \\
\hline S95T003509 & 108:2AR & Whole & $<21.90$ & $<20.8$ & $<21.4$ & & & \\
\hline S95T003508 & 108:2R & Whole & $<27.30$ & $<28.3$ & $<27.8$ & & & \\
\hline S95T003505 & $108: 3$ & Whole & $<22.50$ & $<23.2$ & $<22.9$ & & & \\
\hline Gquids & (2.) & 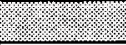 & gg/nI & $28 \mathrm{~g} 1 \mathrm{~m}$ & fg/mil & $\mathrm{gBm}$ & $8.6 \%$ & 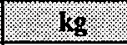 \\
\hline S95T003394 & 108:1 & $\mathrm{DL}$ & $<24.10$ & $<24.1$ & $<24.1$ & \multirow[t]{4}{*}{$<24.1$} & \multirow[t]{4}{*}{$n / a$} & \multirow[t]{4}{*}{$n / a$} \\
\hline S95T003396 & 108:1A & $\mathrm{DL}$ & $<24.10$ & $<24.1$ & $<24.1$ & & & \\
\hline S95T003418 & 108:1AR & $\overline{\mathrm{DL}}$ & $<24.10$ & $<24.1$ & $<24.1$ & & & \\
\hline S95T003422 & 108:2AR & $\mathrm{DL}$ & $<24.10$ & $<24.1$ & $<24.1$ & & & \\
\hline
\end{tabular}


Table A-3. Tank 241-BY-105 Analytical Results: Arsenic.

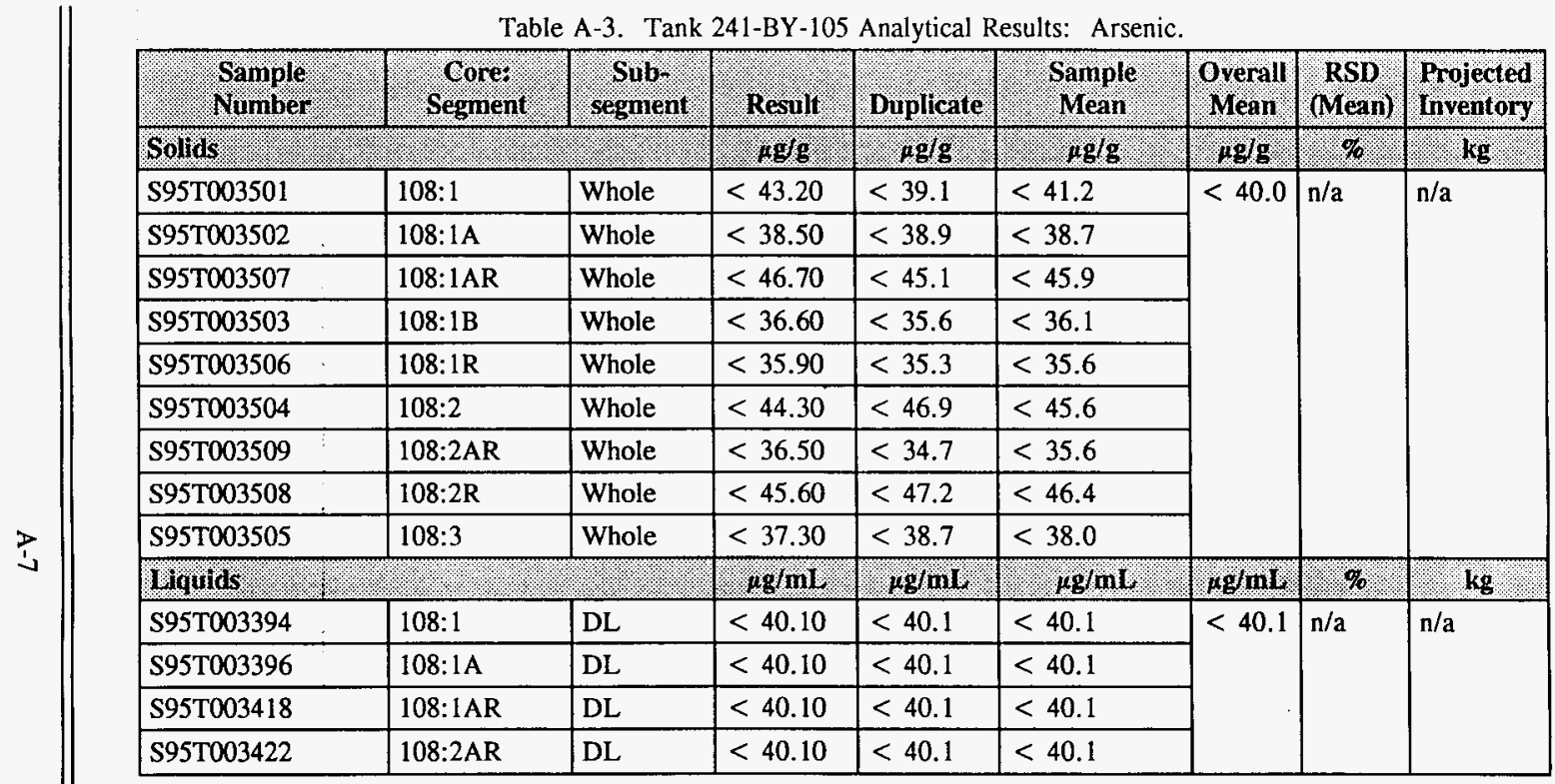


Table A-4. Tank 241-BY-105 Analytical Results: Barium.

\begin{tabular}{|c|c|c|c|c|c|c|c|c|}
\hline Sample & Gore: & Sub & Resull & Duplicate & Sample & $\begin{array}{l}\text { Overall } \\
\text { Mean }\end{array}$ & $\begin{array}{l}\text { RSD } \\
\text { (Vean) }\end{array}$ & $\begin{array}{l}\text { Projected } \\
\text { Inventory }\end{array}$ \\
\hline Solids. & & 4. & $4 \mathrm{glg}$ & 498 & $4 \mathrm{~g} / \mathrm{g}$ & 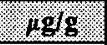 & $\%$ & $\mathrm{~kg}$ \\
\hline S95T003501 & 108:1 & Whole & $<21.60$ & $<19.6$ & $<20.6$ & \multirow[t]{9}{*}{$<20.0$} & \multirow[t]{9}{*}{$n / a$} & \multirow[t]{9}{*}{$n / a$} \\
\hline S95T003502 & 108:1A & Whole & $<19.20$ & $<19.4$ & $<19.3$ & & & \\
\hline S95T003507 & 108:1AR & Whole & $<23.30$ & $<22.6$ & $<23.0$ & & & \\
\hline S95T003503 & 108:1B & Whole & $<18.30$ & $<17.8$ & $<18.1$ & & & \\
\hline S95T003506 & 108:1R & Whole & $<17.90$ & $<17.6$ & $<17.8$ & & & \\
\hline S95T003504 & $108: 2$ & Whole & $<22.10$ & $<23.5$ & $<22.8$ & & & \\
\hline S95T003509 & 108:2AR & Whole & $<18.30$ & $<17.3$ & $<17.8$ & & & \\
\hline S95T003508 & $108: 2 \mathrm{R}$ & Whole & $<22.80$ & $<23.6$ & $<23.2$ & & & \\
\hline S95T003505 & $108: 3$ & Whole & $<18.60$ & $<19.4$ & $<19.0$ & & & \\
\hline Uliguids. & 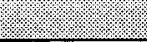 & 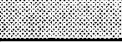 & $4 \mathrm{~g} / \mathrm{ml}$ & $1 \mathrm{~g} / \mathrm{mIl}$ & \%g/mil & $4 \mathrm{giml}$ & $\%$ & 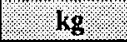 \\
\hline S95T003394 & 108:1 & $\mathrm{DL}$ & $<20.00$ & $<20.0$ & $<20.0$ & \multirow[t]{4}{*}{$<20.0$} & \multirow[t]{4}{*}{$n / a$} & \multirow[t]{4}{*}{$n / a$} \\
\hline S95T003396 & 108:1A & DL & $<20.00$ & $<20.0$ & $<20.0$ & & & \\
\hline S95T003418 & 108:1AR & $\mathrm{DL}$ & $<20.00$ & $<20.0$ & $<20.0$ & & & \\
\hline S95T003422 & 108:2AR & $\mathrm{DL}$ & $<20.00$ & $<20.0$ & $<20.0$ & & & \\
\hline
\end{tabular}


Table A-5. Tank 241-BY-105 Analytical Results: Beryllium. 
Table A-6. Tank 241-BY-105 Analytical Results: Bismuth.

\begin{tabular}{|c|c|c|c|c|c|c|c|c|}
\hline . 4 Sample & Segret & $\begin{array}{l}\text { Sub } \\
\text { segment }\end{array}$ & Result & Duplicate & Sample & Overall & $\begin{array}{l}\text { RSD } \\
\text { (Mean) }\end{array}$ & $\begin{array}{l}\text { Projected } \\
\text { Inventory }\end{array}$ \\
\hline S95T003501 & 108:1 & Whole & 47.60 & 63.10 & $55.35^{\mathrm{QC}: c, \mathrm{c}}$ & \multirow[t]{6}{*}{55.6} & \multirow[t]{6}{*}{17.8} & \multirow[t]{6}{*}{$n / a$} \\
\hline \begin{tabular}{|l|} 
S95T003502 \\
\end{tabular} & 108:1A & Whole & 103 & 43.80 & $73.40^{\mathrm{QC:e}}$ & & & \\
\hline S95T003506 & 108:1R & Whole & $<35.90$ & 48.00 & $42.0^{\mathrm{QC}: \mathrm{c}}$ & & & \\
\hline S95T003504 & $108: 2$ & Whole & $<44.30$ & 128.0 & 86.2 & & & \\
\hline S95T003509 & 108:2AR & Whole & $<36.50$ & 39.70 & 38.1 & & & \\
\hline S95T003508 & $108: 2 \mathrm{R}$ & Whole & $<45.60$ & $<47.2$ & $<46.4$ & & & \\
\hline \$95T003396 & 108:1A & $\mathrm{DL}$ & $<40.10$ & $<40.1$ & $<40.1$ & \multirow{3}{*}{$<40.1$} & \multirow{3}{*}{$n / a$} & \multirow{3}{*}{$n / a$} \\
\hline S95T003418 & 108:1AR & $\mathrm{DL}$ & $<40.10$ & $<40.1$ & $<40.1$ & & & \\
\hline S95T003422 & $108: 2 \mathrm{AR}$ & $\mathrm{DL}$ & $<40.10$ & $<40.1$ & $<40.1$ & & & \\
\hline
\end{tabular}


Table A-7. Tank 241-BY-105 Analytical Results: Boron.

\begin{tabular}{|c|c|c|c|c|c|c|c|c|}
\hline Sample & Sores & Sub- & Resilit. & Dinplicate & Sample & $\begin{array}{l}\text { Overall } \\
\text { Mean }\end{array}$ & $\begin{array}{l}\text { RSD } \\
\text { (Mean) }\end{array}$ & $\begin{array}{l}\text { Projected } \\
\text { Inventory }\end{array}$ \\
\hline Solids & (1. & (1. & $18 \mathrm{~g} / \mathrm{g} / \mathrm{s}$ & $2 \mathrm{~g} / \mathrm{g}$ & $n g / g$ & $\mu \mathrm{g} / \mathrm{g}$ & $\%$ & 18 \\
\hline S95T003501 & $108: 1$ & Whole & $<21.60$ & $<19.6$ & $<20.6$ & \multirow[t]{9}{*}{$<21.5$} & \multirow[t]{9}{*}{$\mathrm{n} / \mathrm{a}$} & \multirow[t]{9}{*}{$n / a$} \\
\hline S95T003502 & 108:1A & Whole & 32.90 & $<19.4$ & 26.2 & & & \\
\hline S95T003507 & 108:1AR & Whole & 25.40 & 23.40 & 24.40 & & & \\
\hline S95T003503 & 108:1B & Whole & $<18.30$ & 20.50 & $<19.4$ & & & \\
\hline \$95T003506 & 108:1R & Whole & $<17.90$ & $<17.6$ & $<17.8$ & & & \\
\hline S95T003504 & $108: 2$ & Whole & $<22.10$ & $<23.5$ & $<22.8$ & & & \\
\hline S95T003509 & $108: 2 \mathrm{AR}$ & Whole & $<18.30$ & $<17.3$ & $<17.8$ & & & \\
\hline S95T003508 & 108:2R & Whole & 35.80 & 25.20 & $30.50^{\text {oC:c }}$ & & & \\
\hline S95T003505 & $108: 3$ & Whole & $<18.60$ & $<19.4$ & $<19.0$ & & & \\
\hline Hiquids & ?. & & $\mu \mathrm{g} / \mathrm{mI}$ & $\mu \mathrm{g} / \mathrm{mi}$ & $\mu \mathrm{g} / \mathrm{mi}$. & $\mu \mathrm{g} / \mathrm{ml}$ & 9 & $\mathrm{~kg}$ \\
\hline \$95T003394 & 108:1 & $\mathrm{DL}$ & 22.70 & 25.30 & 24.00 & \multirow[t]{4}{*}{23.1} & \multirow[t]{4}{*}{11.1} & \multirow[t]{4}{*}{$n / a$} \\
\hline S95T003396 & 108:1A & $\mathrm{DL}$ & 32.50 & 29.10 & 30.80 & & & \\
\hline S95T003418 & 108:1AR & $\overline{D L}$ & 22.70 & 23.30 & 23.00 & & & \\
\hline S95T003422 & 108:2AR & $\mathrm{DL}$ & 20.4 & $<20.0$ & 20.2 & & & \\
\hline
\end{tabular}


Table A-8. Tank 241-BY-105 Analytical Results: Cadmium.

\begin{tabular}{|c|c|c|c|c|c|c|c|c|}
\hline $\begin{array}{l}\text { Sample } \\
\text { Number } \\
\text { Nume }\end{array}$ & $\begin{array}{l}\text { Core? } \\
\text { Segment } \\
\end{array}$ & $\begin{array}{l}\text { Sub- } \\
\text { segument }\end{array}$ & Result & Duplicate & \begin{tabular}{|c|} 
Sample \\
Mean
\end{tabular} & $\begin{array}{l}\text { Overall } \\
\text { Mean }\end{array}$ & $\begin{array}{l}\text { RSD } \\
\text { (Mean) }\end{array}$ & $\begin{array}{l}\text { Projected } \\
\text { Inventory }\end{array}$ \\
\hline Solids: & $\sqrt{15}$ & 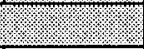 & $1 \mathrm{~g} / \mathrm{g}$ & $\mu \mathrm{gg}$ & $\sqrt{7 g / g}$ & $\mu \mathrm{g} / \mathrm{g}$ & $\%$ & $\sqrt{16 g} \cdot$ \\
\hline S95T003501 & 108:1 & Whole & 5.450 & 6.620 & 6.035 & \multirow[t]{9}{*}{6.54} & \multirow[t]{9}{*}{25.3} & \multirow[t]{9}{*}{$n / a$} \\
\hline S95T003502 & 108:1A & \begin{tabular}{|l|} 
Whole \\
\end{tabular} & 9.650 & \begin{tabular}{|l|}
8.840 \\
\end{tabular} & 9.245 & & & \\
\hline S95T003507 & 108:1AR & Whole & 5.490 & 7.420 & $6.455^{\mathrm{oC}: c}$ & & & \\
\hline S95T003503 & 108:1B & Whole & 8.560 & 8.420 & 8.490 & & & \\
\hline S95T003506 & 108:1R & Whole & 5.310 & 6.940 & $6.125^{\mathrm{QC:c}}$ & & & \\
\hline S95T003504 & $108: 2$ & Whole & 5.610 & 6.280 & 5.945 & & & \\
\hline S95T003509 & 108:2AR & Whole & 11.70 & 10.90 & 11.30 & & & \\
\hline S95T003508 & $108: 2 \mathrm{R}$ & Whole & 11.10 & 11.70 & 11.40 & & & \\
\hline S95T003505 & $108: 3$ & Whole & $<1.860$ & 3.750 & 2.81 & & & \\
\hline \multicolumn{3}{|c|}{ Miquids : } & (19/mis: & 1.g7nil: & $1.1 / \mathrm{gril}$ & $/ \mathrm{g} / \mathrm{ml}$ & 1.9 & .128 \\
\hline S95T003394 & 108:1 & $\mathrm{DL}$ & $<2.000$ & $<2.00$ & $<2.00$ & \multirow[t]{4}{*}{$<2.00$} & \multirow[t]{4}{*}{$n / a$} & \multirow[t]{4}{*}{$n / a$} \\
\hline S95T003396 & $108: 1 \mathrm{~A}$ & DL & $<2.000$ & $<2.00$ & $<2.00$ & & & \\
\hline S95T003418 & 108:1AR & DL & $<2.000$ & $<2.00$ & $<2.00$ & & & \\
\hline S95T003422 & $108: 2 \mathrm{AR}$ & $\overline{D L}$ & $<2.000$ & $<2.00$ & $<2.00$ & & & \\
\hline
\end{tabular}


Table A-9. Tank 241-BY-105 Analytical Results: Calcium.

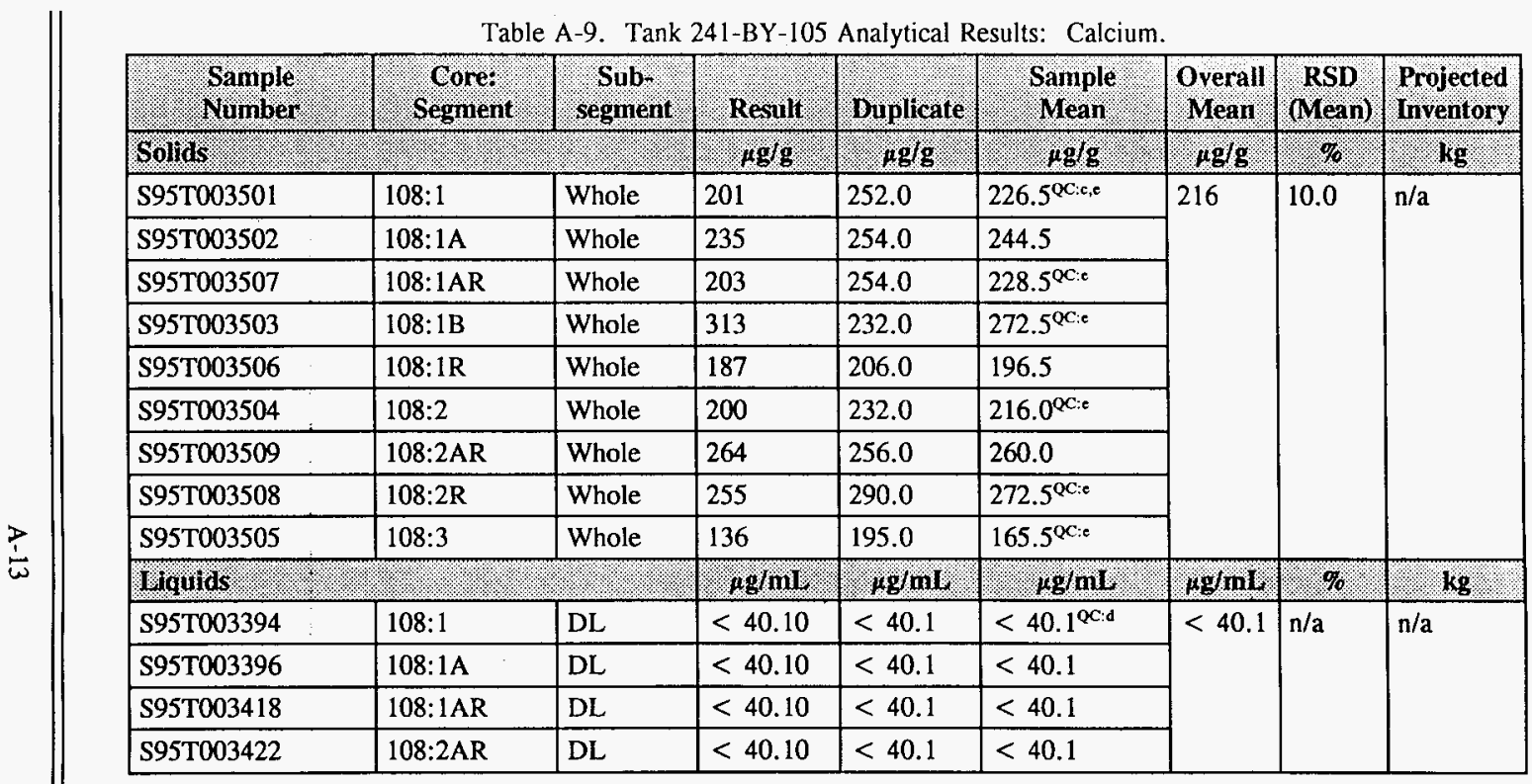


Table A-10. Tank 241-BY-105 Analytical Results: Cerium.

\begin{tabular}{|c|c|c|c|c|c|c|c|c|}
\hline Sample & Segrest & Sub & Resuli & Duplicate. & $\begin{array}{l}\text { Sample } \\
\text { Mean }\end{array}$ & $\begin{array}{l}\text { Orerall } \\
\text { Mean }\end{array}$ & $\begin{array}{c}\text { RSD } \\
\text { (Mean) }\end{array}$ & $\begin{array}{l}\text { Projected } \\
\text { Inventory }\end{array}$ \\
\hline Sollas : & 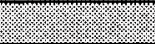 & (1.7. & $1 / \mathrm{g} / \mathrm{g}$ & $\mu \mathrm{g} / \mathrm{g}$. & $r g / g$ & $10 \mathrm{~g} / \mathrm{g}$ & $1 . \%$ & kg \\
\hline S95T003501 & 108:1 & Whole & $<43.20$ & $<39.1$ & $<41.2$ & \multirow[t]{9}{*}{$<40.0$} & \multirow[t]{9}{*}{$n / a$} & \multirow[t]{9}{*}{$n / a$} \\
\hline S95T003502 & 108:1A & Whole & $<38.50$ & $<38.9$ & $<38.7$ & & & \\
\hline S95T003507 & 108:1AR & Whole & $<46.70$ & $<45.1$ & $<45.9$ & & & \\
\hline S95T003503 & 108:1B & Whole & $<36.60$ & $<35.6$ & $<36.1$ & & & \\
\hline S95T003506 & 108:1R & Whole & $<35.90$ & $<35.3$ & $<35.6$ & & & \\
\hline S95T003504 & $108: 2$ & Whole & $<44.30$ & $<46.9$ & $<45.6$ & & & \\
\hline S95T003509 & 108:2AR & Whole & $<36.50$ & $<34.7$ & $<35.6$ & & & \\
\hline S95T003508 & $108: 2 \mathrm{R}$ & Whole & $<45.60$ & $<47.2$ & $<46.4$ & & & \\
\hline S95T003505 & $108: 3$ & Whole & $<37.30$ & $<38.7$ & $<38.0$ & & & \\
\hline \multicolumn{3}{|l|}{ Higuras } & $\mu \mathrm{g} / \mathrm{m}$ & $\mu g / n$ & $.4 \mathrm{gmo}$ & $160 / 11$ & $\%$ & kg. \\
\hline S95T003394 & $108: 1$ & $\mathrm{DL}$ & $<40.10$ & $<40.1$ & $<40.1$ & \multirow[t]{4}{*}{$<40.1$} & \multirow[t]{4}{*}{$n / a$} & \multirow[t]{4}{*}{$n / a$} \\
\hline S95T003396 & 108:1A & $\mathrm{DL}$ & $<40.10$ & $<40.1$ & $<40.1$ & & & \\
\hline S95T003418 & 108:1AR & $\mathrm{DL}$ & $<40.10$ & $<40.1$ & $<40.1$ & & & \\
\hline S95T003422 & 108:2AR & $\mathrm{DL}$ & $<40.10$ & $<40.1$ & $<40.1$ & & & \\
\hline
\end{tabular}


Table A-11. Tank 241-BY-105 Analytical Results: Chromium.

\begin{tabular}{|c|c|c|c|c|c|c|c|c|}
\hline $\begin{array}{l}\text { Sample } \\
\text { Number }\end{array}$ & $\begin{array}{l}\text { Core: } \\
\text { Segment }\end{array}$ & $\begin{array}{l}\text { Sub- } \\
\text { segment }\end{array}$ & Result & Duplicate & $\begin{array}{l}\text { Sample } \\
\text { Mean }\end{array}$ & $\begin{array}{l}\text { Overall } \\
\text { Mean }\end{array}$ & $\begin{array}{c}\text { RSD } \\
\text { (Mean) }\end{array}$ & $\begin{array}{l}\text { Projected } \\
\text { Inventory }\end{array}$ \\
\hline Solids & (I) & 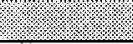 & $1.9 \mathrm{~g} / \mathrm{g}$ & $\mathrm{ag} / \mathrm{g}$ & $\mathrm{mg} / \mathrm{g}$ & $\mu g / g$ & $8 \%$ & kg \\
\hline S95T003501 & 108:1 & Whole & 240 & 266.0 & 253.0 & \multirow[t]{9}{*}{321} & \multirow[t]{9}{*}{12.4} & \multirow[t]{9}{*}{$n / a$} \\
\hline S95T003502 & 108:1A & Whole & 259 & 248.0 & 253.5 & & & \\
\hline S95T003507 & 108:1AR & Whole & 258 & 395.0 & $326.5^{Q C: e}$ & & & \\
\hline S95T003503 & 108:1B & Whole & 300 & 296.0 & 298.0 & & & \\
\hline S95T003506 & 108:1R & Whole & 297 & 352.0 & 324.5 & & & \\
\hline S95T003504 & 108:2 & Whole & 361 & 382.0 & 371.5 & & & \\
\hline S95T003509 & 108:2AR & Whole & 374 & 448.0 & 411.0 & & & \\
\hline S95T003508 & $108: 2 \mathrm{R}$ & Whole & 403 & 433.0 & 418.0 & & & \\
\hline S95T003505 & 108:3 & Whole & 162 & 383.0 & $272.5^{\infty \mathrm{C:e}}$ & & & \\
\hline Gquids & 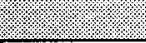 & 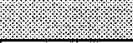 & $18 \mathrm{~g} / \mathrm{ml}$ & jgrint. & ugrmi & $\mu \mathrm{g} / \mathrm{ml}$. & $1.8 \%$ & $=.1 \mathrm{~kg}$ \\
\hline S95T003394 & 108:1 & DL & 1,220 & 1,270 & 1,240 & \multirow[t]{4}{*}{1,320} & \multirow[t]{4}{*}{5.3} & \multirow[t]{4}{*}{$n / a$} \\
\hline S95T003396 & 108:1A & $\mathrm{DL}$ & 1,290 & 1,230 & 1,260 & & & \\
\hline S95T003418 & 108:1AR & DL & 1,260 & 1,230 & 1,240 & & & \\
\hline S95T003422 & 108:2AR & $\mathrm{DL}$ & 1,420 & 1,360 & 1,390 & & & \\
\hline
\end{tabular}


Table A-12. Tank 241-BY-105 Analytical Results: Cobalt.

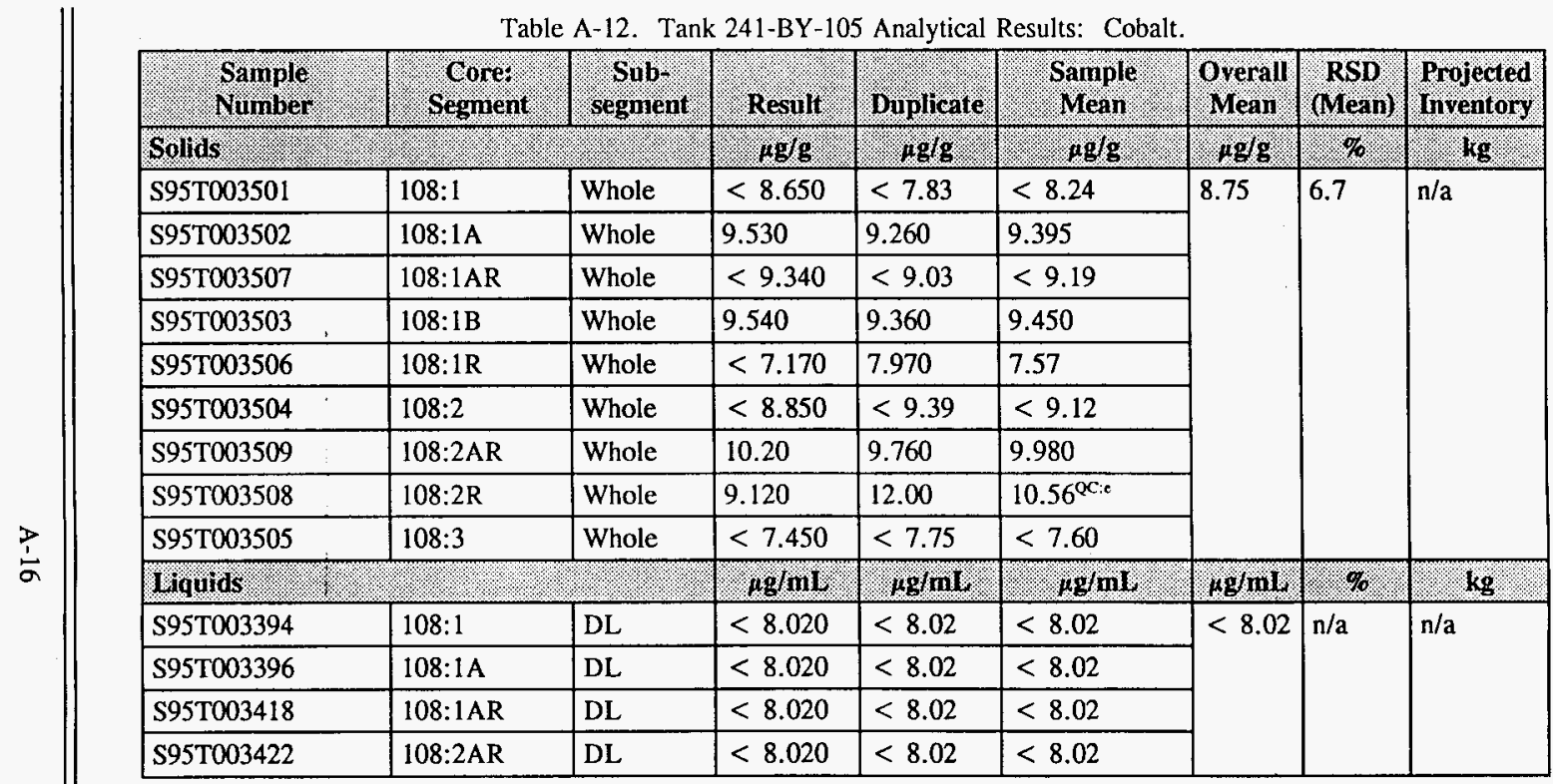


Table A-13. Tank 241-BY-105 Analytical Results: Copper.

\begin{tabular}{|c|c|c|c|c|c|c|c|c|}
\hline $\begin{array}{l}\text { Sample } \\
\text { Number }\end{array}$ & $\begin{array}{l}\text { Cort } \\
\text { Segment }\end{array}$ & $\begin{array}{l}\text { Sub- } \\
\text { segment }\end{array}$ & Result & Duplicate & $\begin{array}{l}\text { Sample } \\
\text { Mean }\end{array}$ & $\begin{array}{c}\text { Overall } \\
\text { Mean }\end{array}$ & $\begin{array}{c}\text { RSD } \\
\text { (Mean) }\end{array}$ & $\begin{array}{l}\text { Projected } \\
\text { Inventory }\end{array}$ \\
\hline Solids & 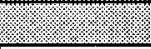 & 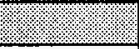 & $\mu g / g$ & $\mu \mathrm{g} / \mathrm{g}$ & ag/g. & $\mu \mathrm{g} / \mathrm{g}$ & 9. & $\mathrm{~kg}$. \\
\hline S95T003501 & 108: 1 & Whole & 5.170 & 4.100 & $4.635^{\text {QC:e }}$ & \multirow[t]{9}{*}{7.57} & \multirow[t]{9}{*}{31.1} & \multirow[t]{9}{*}{$\mathrm{n} / \mathrm{a}$} \\
\hline S95T003502 & $108: 1 \mathrm{~A}$ & Whole & 56.60 & 4.780 & $30.69^{\mathrm{aC}: \mathrm{c}}$ & & & \\
\hline S95T003507 & 108:1AR & Whole & 5.500 & $<4.51$ & 5.01 & & & \\
\hline S95T003503 & 108:1B & Whole & 5.820 & $<3.56$ & 4.69 & & & \\
\hline S95T003506 & 108:1R & Whole & 9.340 & 12.10 & $10.72^{\mathrm{QCec}}$ & & & \\
\hline \$95T003504 & $108: 2$ & Whole & $<4.430$ & $<4.69$ & $<4.56$ & & & \\
\hline S95T003509 & 108:2AR & Whole & 11.20 & 8.250 & $9.725^{\mathrm{QC:e}}$ & & & \\
\hline S95T003508 & $108: 2 \mathrm{R}$ & Whole & 9.100 & 8.870 & 8.985 & & & \\
\hline S95T003505 & $108: 3$ & Whole & $<3.730$ & $<3.87$ & $<3.80$ & & & \\
\hline \multicolumn{3}{|c|}{ Liquids : in : } & $\mu \mathrm{g} / \mathrm{ml}$ & $u \mathrm{~g} / \mathrm{ml}$. & $\mu \mathrm{g} / \mathrm{mL}$ & $\mathrm{kg} / \mathrm{mi}$. & 9 & 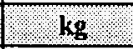 \\
\hline S95T003394 & 108:1 & DL & $<4.010$ & $<4.01$ & $<4.01$ & \multirow[t]{4}{*}{$<4.01$} & \multirow[t]{4}{*}{$\mathrm{n} / \mathrm{a}$} & \multirow[t]{4}{*}{$\mathrm{n} / \mathrm{a}$} \\
\hline S95T003396 & 108:1A & $\mathrm{DL}$ & $<4.010$ & $<4.01$ & $<4.01$ & & & \\
\hline S95T003418 & 108:1AR & $\mathrm{DL}$ & $<4.010$ & $<4.01$ & $<4.01$ & & & \\
\hline S95T003422 & 108:2AR & $\mathrm{DL}$ & $<4.010$ & $<4.01$ & $<4.01$ & & & \\
\hline
\end{tabular}


Table A-14. Tank 241-BY-105 Analytical Results: Iron.

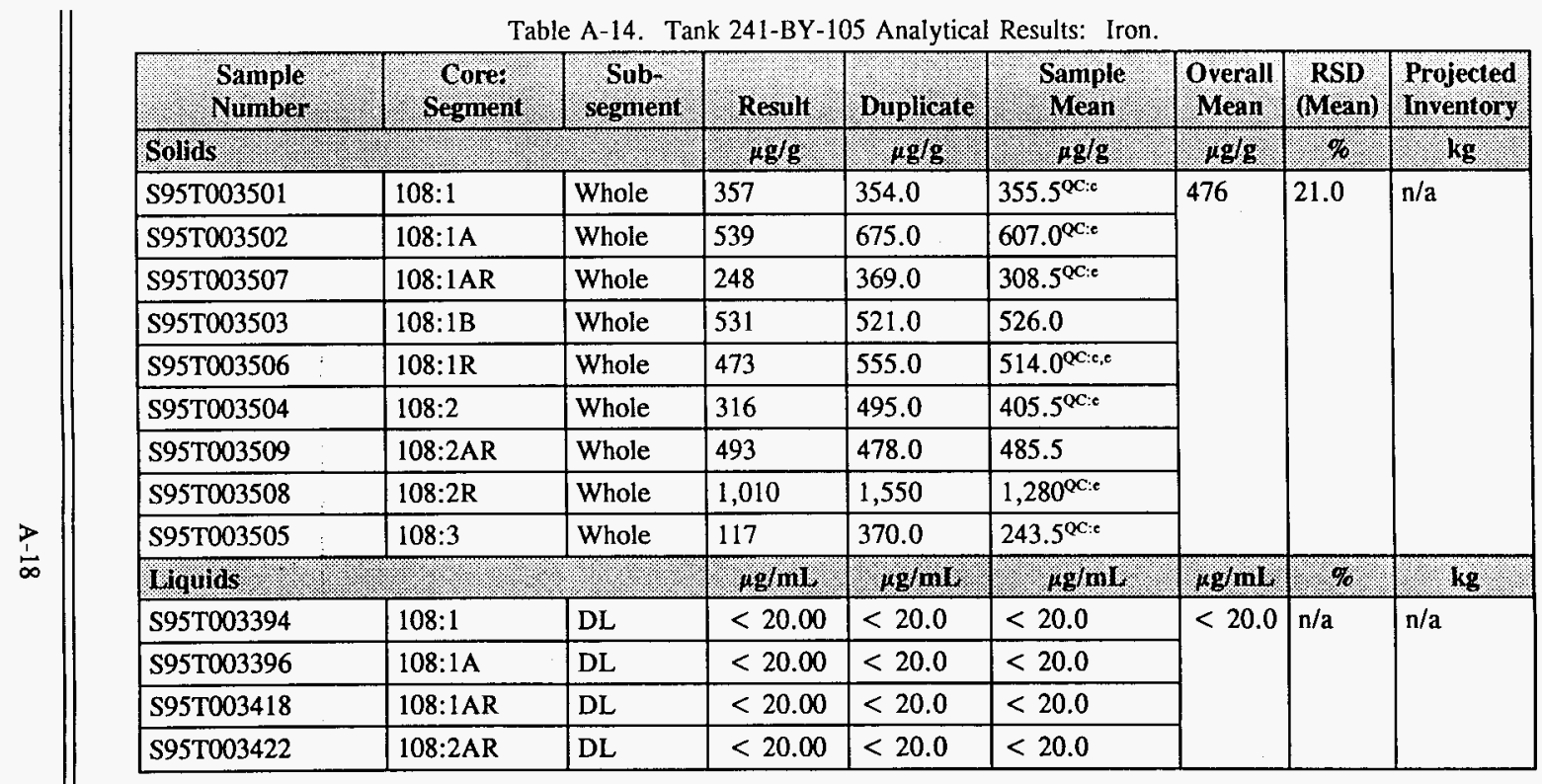


Table A-15. Tank 241-BY-105 Analytical Results: Lanthanum.

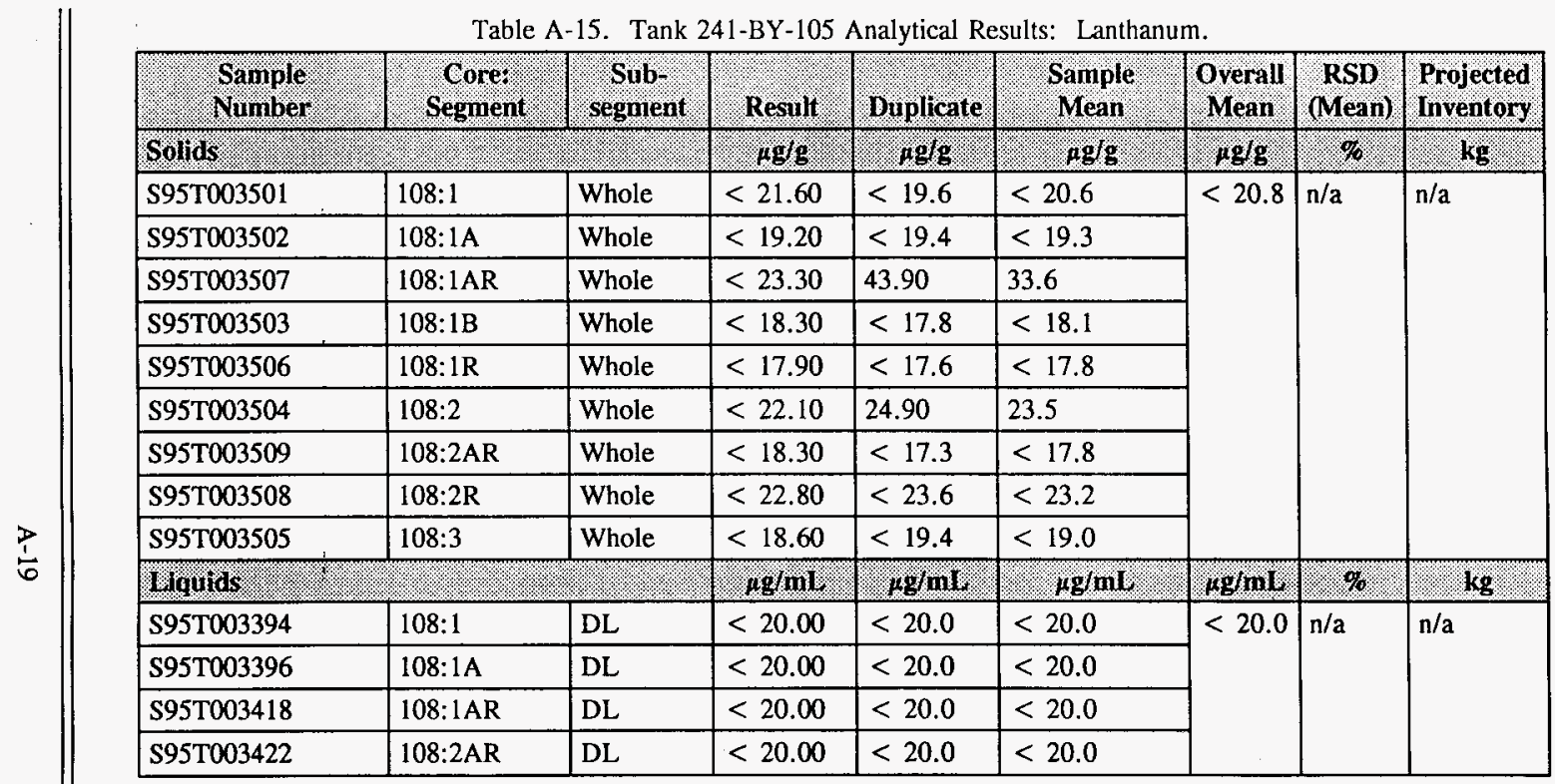


Table A-16. Tank 241-BY-105 Analytical Results: Lead.

\begin{tabular}{|c|c|c|c|c|c|c|c|c|}
\hline Sample & Segment & Sutb & Resuil & Buplicate & Sample & $\begin{array}{l}\text { Orerall } \\
\text { Mean. }\end{array}$ & $\begin{array}{l}\text { RSD } \\
(\text { Mean) }\end{array}$ & $\begin{array}{l}\text { Projected } \\
\text { Inventory }\end{array}$ \\
\hline Solids: & & I & $14 \mathrm{~g} / \mathrm{g}$ & $49 / 8$ & $\mu g / g$ & $14 \mathrm{gr}$ & $\%$ & .48 \\
\hline S95T003501 & 108:1 & Whole & 49.30 & 53.10 & 51.20 & \multirow[t]{9}{*}{50.3} & \multirow[t]{9}{*}{10.7} & \multirow[t]{9}{*}{$\mathrm{n} / \mathrm{a}$} \\
\hline S95T003502 & 108:1A & Whole & 54.40 & 54.70 & 54.55 & & & \\
\hline S95T003507 & 108:1AR & Whole & $<46.70$ & $<45.1$ & $<45.9$ & & & \\
\hline S95T003503 & 108:1B & Whole & 51.00 & 56.50 & 53.75 & & & \\
\hline S95T003506 & 108:1R & Whole & 41.70 & 54.80 & $48.25^{\mathrm{QC}: \mathrm{e}}$ & & & \\
\hline S95T003504 & $108: 2$ & Whole & $<44.30$ & $<46.9$ & $<45.6$ & & & \\
\hline S95T003509 & 108:2AR & Whole & 61.60 & 59.30 & 60.45 & & & \\
\hline S95T003508 & $108: 2 \mathrm{R}$ & Whole & 72.00 & 87.20 & 79.60 & & & \\
\hline S95T003505 & $108: 3$ & Whole & $<37.30$ & 39.50 & 38.4 & & & \\
\hline \multicolumn{3}{|l|}{ biquids } & $19 \mathrm{~g} / \mathrm{ml}$ & $1 / \mathrm{g} / \mathrm{ml}$ & . $1 \mathrm{~g} / \mathrm{mI}$ & $4 \mathrm{~g} / \mathrm{nL}$ & $9 \%$ & kg \\
\hline S95T003394 & 108:1 & DL & 68.00 & 73.90 & 70.95 & \multirow[t]{4}{*}{80.7} & \multirow[t]{4}{*}{10.2} & \multirow[t]{4}{*}{$\mathrm{n} / \mathrm{a}$} \\
\hline S95T003396 & 108:1A & DL & 68.90 & 66.30 & 67.60 & & & \\
\hline S95T003418 & 108:1AR & DL & 79.60 & 78.30 & 78.95 & & & \\
\hline S95T003422 & $108: 2 \mathrm{AR}$ & DL & 91.80 & 85.90 & 88.85 & & & \\
\hline
\end{tabular}


Table A-17. Tank 241-BY-105 Analytical Results: Magnesium.

\begin{tabular}{|c|c|c|c|c|c|c|c|c|}
\hline Sample & $\begin{array}{l}\text { Corre } \\
\text { Segment }\end{array}$ & subs & Ressilt & Diuplicate & Sample & Overall & $\begin{array}{l}\text { RSD } \\
\text { (Mean) }\end{array}$ & $\begin{array}{l}\text { Projected } \\
\text { Inventory }\end{array}$ \\
\hline Solids & (2) & (3. & $4 \mathrm{~g} / \mathrm{g}$ & $109 / \mathrm{g}$ & $198 / 8$ & $19 / 9$ & $\%$ & $\mathrm{~kg}$ \\
\hline \$95T003501 & 108:1 & Whole & $<43.20$ & $<39.1$ & $<41.2$ & \multirow[t]{9}{*}{$<40.0$} & \multirow[t]{9}{*}{$n / a$} & \multirow[t]{9}{*}{$n / a$} \\
\hline S95T003502 & 108:1A & Whole & $<38.50$ & $<38.9$ & $<38.7$ & & & \\
\hline \$95T003507 & 108: 1AR & Whole & $<46.70$ & $<45.1$ & $<45.9$ & & & \\
\hline S95T003503 & 108:1B & Whole & $<36.60$ & $<35.6$ & $<36.1$ & & & \\
\hline S95T003506 & 108:1R & Whole & $<35.90$ & $<35.3$ & $<35.6$ & & & \\
\hline S95T003504 & $108: 2$ & Whole & $<44.30$ & $<46.9$ & $<45.6$ & & & \\
\hline S95T003509 & 108:2AR & Whole & $<36.50$ & $<34.7$ & $<35.6$ & & & \\
\hline S95T003508 & 108:2R & Whole & $<45.60$ & $<47.2$ & $<46.4$ & & & \\
\hline S95T003505 & $108: 3$ & Whole & $<37.30$ & $<38.7$ & $<38.0$ & & & \\
\hline Mquids & (2. & & $\mu \mathrm{g} / \mathrm{mI}$ & $\mu \mathrm{g} / \mathrm{mi}$ & sg/mit & $1 \mathrm{~g} / \mathrm{il}$ & $1 \%$ & 1.68 \\
\hline S95T003394 & 108:1 & DL & $<40.10$ & $<40.1$ & $<40.1$ & \multirow[t]{4}{*}{$<40.1$} & \multirow[t]{4}{*}{$\mathrm{n} / \mathrm{a}$} & \multirow[t]{4}{*}{$n / a$} \\
\hline S95T003396 & 108:1A & DL & $<40.10$ & $<40.1$ & $<40.1$ & & & \\
\hline S95T003418 & 108:1AR & $\mathrm{DL}$ & $<40.10$ & $<40.1$ & $<40.1$ & & & \\
\hline S95T003422 & 108:2AR & $\mathrm{DL}$ & $<40.10$ & $<40.1$ & $<40.1$ & & & \\
\hline
\end{tabular}


Table A-18. Tank 241-BY-105 Analytical Results: Manganese.

\begin{tabular}{|c|c|c|c|c|c|c|c|c|}
\hline $\begin{array}{l}\text { Sample } \\
\text { unmber }\end{array}$ & Sogre. & segub- & t. & Duplicate & $\begin{array}{l}\text { Sample } \\
\text { Mean }\end{array}$ & $\begin{array}{l}\text { Overall } \\
\text { Mean }\end{array}$ & (MSD) & $\begin{array}{l}\text { Projected } \\
\text { Inventory }\end{array}$ \\
\hline Sollds & F/ & 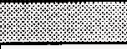 & $\mu \mathrm{gs}$ & $\mu g / g$, & $.4 \mathrm{~g} / \mathrm{g}$ & $\mu \mathrm{g} g$ & $1 \%$ & (3g \\
\hline S95T003501 & 108:1 & Whole & 20.20 & 22.50 & 21.35 & \multirow[t]{9}{*}{54.8} & \multirow[t]{9}{*}{30.3} & \multirow[t]{9}{*}{$n / a$} \\
\hline S95T003502 & 108:1A & Whole & 32.20 & 31.70 & 31.95 & & & \\
\hline S95T003507 & 108:1AR & Whole & 17.30 & 25.10 & $21.20^{Q C: c}$ & & & \\
\hline S95T003503 & 108:1B & Whole & 34.40 & 35.00 & 34.70 & & & \\
\hline S95T003506 & 108:1R & Whole & 19.10 & 25.40 & $22.25^{\mathrm{QC}: \mathrm{e}}$ & & & \\
\hline S95T003504 & $108: 2$ & Whole & 84.90 & 89.60 & 87.25 & & & \\
\hline S95T003509 & 108:2AR & Whole & 34.10 & 35.10 & 34.60 & & & \\
\hline S95T003508 & $108: 2 \mathrm{R}$ & \begin{tabular}{|l|} 
Whole \\
\end{tabular} & 42.20 & 48.80 & 45.50 & & & \\
\hline S95T003505 & $108: 3$ & Whole & 26.80 & 138.0 & $82.40^{\text {oc:e }}$ & & & \\
\hline \multicolumn{3}{|l|}{ Riquids } & $\mu \mathrm{g} / \mathrm{mL}$ & $\mu \mathrm{g} / \mathrm{mi}$ & $1 / \mathrm{g} / \mathrm{ml}$ & Ag/nl: & $\%$ & 1.168 \\
\hline S95T003394 & $108: 1$ & DL & $<4.010$ & $<4.01$ & $<4.01$ & \multirow[t]{4}{*}{$<4.01$} & \multirow[t]{4}{*}{$n / a$} & \multirow[t]{4}{*}{$n / a$} \\
\hline S95T003396 & 108:1A & $\mathrm{DL}$ & $<4.010$ & $<4.01$ & $<4.01$ & & & \\
\hline S95T003418 & 108:1AR & $\mathrm{DL}$ & $<4.010$ & $<4.01$ & $<4.01$ & & & \\
\hline S95T003422 & $108: 2 \mathrm{AR}$ & $\mathrm{DL}$ & $<4.010$ & $<4.01$ & $<4.01$ & & & \\
\hline
\end{tabular}


Table A-19. Tank 241-BY-105 Analytical Results: Molydenum.

\begin{tabular}{|c|c|c|c|c|c|c|c|c|}
\hline $\begin{array}{l}\text { Sample. } \\
\text { Number }\end{array}$ & Segres & Sugment & Resiit: & Duplicate & $\begin{array}{l}\text { Sample } \\
\text { Mean }\end{array}$ & Overall & $\begin{array}{c}\text { RSD } \\
\text { (Mean) }\end{array}$ & $\begin{array}{l}\text { Projected } \\
\text { Inventory }\end{array}$ \\
\hline Solins & (3.6. & (3. & $.9 \mathrm{~g} g$ & $19 g 8$ & $109 / \mathrm{g}$ & $\mu \mathrm{g} / \mathrm{g}$ & \% $\%$ & $.6 \mathrm{~kg}$ \\
\hline S95T003501 & 108:1 & Whole & $<21.60$ & $<19.6$ & $<20.6$ & \multirow[t]{9}{*}{$<20.0$} & \multirow[t]{9}{*}{$n / a$} & \multirow[t]{9}{*}{$\mathrm{n} / \mathrm{a}$} \\
\hline \$95T003502 & 108:1A & Whole & $<19.20$ & $<19.4$ & $<19.3$ & & & \\
\hline S95T003507 & 108:1AR & Whole & $<23.30$ & $<22.6$ & $<23.0$ & & & \\
\hline S95T003503 & 108:1B & Whole & $<18.30$ & $<17.8$ & $<18.1$ & & & \\
\hline S95T003506 & 108:1R & Whole & $<17.90$ & $<17.6$ & $<17.8$ & & & \\
\hline S95T003504 & 108:2 & Whole & $<22.10$ & $<23.5$ & $<22.8$ & & & \\
\hline \$95T003509 & 108:2AR & Whole & $<18.30$ & $<17.3$ & $<17.8$ & & & \\
\hline S95T003508 & $108: 2 \mathrm{R}$ & Whole & $<22.80$ & $<23.6$ & $<23.2$ & & & \\
\hline S95T003505 & $108: 3$ & Whole & $<18.60$ & $<19.4$ & $<19.0$ & & & \\
\hline grquids & & 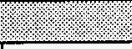 & $1 \mathrm{gin}$ & $1.9 \mathrm{ml}$ & $.4 \mathrm{~g} / \mathrm{ml}$ & $1 / \mathrm{g} / \mathrm{ml}$ & 1.8 & 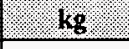 \\
\hline S95T003394 & 108:1 & $\mathrm{DL}$ & 25.10 & 26.80 & 25.95 & \multirow[t]{4}{*}{28.9} & \multirow[t]{4}{*}{7.8} & \multirow[t]{4}{*}{$n / a$} \\
\hline S95T003396 & 108:1A & $\mathrm{DL}$ & 27.50 & 25.00 & 26.25 & & & \\
\hline S95T003418 & 108:1AR & $\mathrm{DL}$ & 27.70 & 27.80 & 27.75 & & & \\
\hline S95T003422 & 108:2AR & $\mathrm{DL}$ & 32.00 & 30.30 & 31.15 & & & \\
\hline
\end{tabular}


Table A-20. Tank 241-BY-105 Analytical Results: Neodymium.

\begin{tabular}{|c|c|c|c|c|c|c|c|c|}
\hline $\begin{array}{l}\text { Sample } \\
\text { Number }\end{array}$ & Sore. & $\begin{array}{l}\text { Sub- } \\
\text { segment }\end{array}$ & Resillt & Duplicate & Sample & $\begin{array}{c}\text { Overall } \\
\text { Mean }\end{array}$ & $\begin{array}{c}\text { RSD } \\
\text { (Mean) }\end{array}$ & $\begin{array}{l}\text { Projected } \\
\text { Inventory }\end{array}$ \\
\hline Solids & (1) & 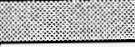 & $10 / 9$ & 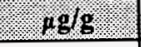 & rgog & $\mu \mathrm{g} / \mathrm{g} / /$ & \%. & lgg \\
\hline S95T003501 & 108:1 & Whole & $<43.20$ & $<39.1$ & $<41.2$ & \multirow[t]{9}{*}{$<40.0$} & \multirow[t]{9}{*}{$n / a$} & \multirow[t]{9}{*}{$n / a$} \\
\hline S95T003502 & 108:1A & Whole & $<38.50$ & $<38.9$ & $<38.7$ & & & \\
\hline \$95T003507 & 108:1AR & Whole & $<46.70$ & $<45.1$ & $<45.9$ & & & \\
\hline S95T003503 & 108:1B & Whole & $<36.60$ & $<35.6$ & $<36.1$ & & & \\
\hline S95T003506 & 108:1R & Whole & $<35.90$ & $<35.3$ & $<35.6$ & & & \\
\hline S95T003504 & $108: 2$ & Whole & $<44.30$ & $<46.9$ & $<45.6$ & & & \\
\hline S95T003509 & 108:2AR & Whole & $<36.50$ & $<34.7$ & $<35.6$ & & & \\
\hline S95T003508 & $108: 2 \mathrm{R}$ & Whole & $<45.60$ & $<47.2$ & $<46.4$ & & & \\
\hline S95T003505 & $108: 3$ & Whole & $<37.30$ & $<38.7$ & $<38.0$ & & & \\
\hline \multicolumn{3}{|l|}{ Liquids: } & $48 / \mathrm{mi}$ & $\mu \mathrm{g} / \mathrm{mL}$ & . $1 \mathrm{gmi}$ & $2 \mathrm{~g} / \mathrm{m}$ & $\%$ & $\mathrm{~kg}$ \\
\hline S95T003394 & 108: 1 & $\mathrm{DL}$ & $<40.10$ & $<40.1$ & $<40.1$ & \multirow[t]{4}{*}{$<40.1$} & \multirow[t]{4}{*}{$n / a$} & \multirow[t]{4}{*}{$n / a$} \\
\hline S95T003396 & 108:1A & $\mathrm{DL}$ & $<40.10$ & $<40.1$ & $<40.1$ & & & \\
\hline S95T003418 & 108:1AR & $\mathrm{DL}$ & $<40.10$ & $<40.1$ & $<40.1$ & & & \\
\hline S95T003422 & $108: 2 \mathrm{AR}$ & $\mathrm{DL}$ & $<40.10$ & $<40.1$ & $<40.1$ & & & \\
\hline
\end{tabular}


Table A-21. Tank 241-BY-105 Analytical Results: Nickel.

\begin{tabular}{|c|c|c|c|c|c|c|c|c|}
\hline $\begin{array}{l}\text { Sample, } \\
\text { Tamber }\end{array}$ & Gorer & $\begin{array}{l}\text { Subr } \\
\text { segrient }\end{array}$ & Resiil & Duplicate & $\begin{array}{l}\text { Sample. } \\
\text {. Mean }\end{array}$ & $\begin{array}{l}\text { Overall } \\
\text { Mean }\end{array}$ & (Mean) & $\begin{array}{l}\text { Projected } \\
\text { Inventory }\end{array}$ \\
\hline Solins & (3. & & $4.9 \mathrm{gg}$ & $\mu g / g$, & $\mu g / g$ & $1 \mathrm{~g} / \mathrm{g}$ & $\%$ & $1.6 \mathrm{~g}$ \\
\hline S95T003501 & 108:1 & Whole & 56.40 & 62.20 & $59.30^{\mathrm{QC:c}}$ & \multirow[t]{9}{*}{75.9} & \multirow[t]{9}{*}{10.2} & \multirow[t]{9}{*}{$\mathrm{n} / \mathrm{a}$} \\
\hline \$95T003502 & 108:1A & Whole & 106 & 99.80 & 102.9 & & & \\
\hline S95T003507 & 108:1AR & Whole & 54.80 & 79.20 & $67.00^{\mathrm{QC:c}}$ & & & \\
\hline S95T003503 & 108:1B & Whole & 113 & 115.0 & 114.0 & & & \\
\hline S95T003506 & 108:1R & Whole & 58.90 & 76.00 & $67.45^{\mathrm{QC}: c, c}$ & & & \\
\hline S95T003504 & $108: 2$ & Whole & 69.50 & 75.30 & 72.40 & & & \\
\hline S95T003509 & 108:2AR & Whole & 106 & 103.0 & 104.5 & & & \\
\hline S95T003508 & $108: 2 \mathrm{R}$ & Whole & 109 & 122.0 & $115.5^{\text {oC:e }}$ & & & \\
\hline S95T003505 & $108: 3$ & Whole & 21.10 & 75.30 & $48.20^{\mathrm{ocic}}$ & & & \\
\hline \multicolumn{3}{|c|}{ (1) } & $\mu \mathrm{g} / \mathrm{mi}$ & $\mu \mathrm{g} / \mathrm{ni}$ & $.199 / 1 \mathrm{l}$ & 1 /mi &.$\%$ & $.18 \mathrm{~g}$ \\
\hline S95T003394 & $108: 1$ & $\mathrm{DL}$ & $<8.020$ & $<8.02$ & $<8.02$ & \multirow[t]{4}{*}{$<8.02$} & \multirow[t]{4}{*}{$n / a$} & \multirow[t]{4}{*}{$\mathrm{n} / \mathrm{a}$} \\
\hline S95T003396 & 108:1A & $\mathrm{DL}$ & $<8.020$ & $<8.02$ & $<8.02$ & & & \\
\hline S95T003418 & 108:1AR & $\mathrm{DL}$ & $<8.020$ & $<8.02$ & $<8.02$ & & & \\
\hline S95T003422 & 108:2AR & $\mathrm{DL}$ & $<8.020$ & $<8.02$ & $<8.02$ & & & \\
\hline
\end{tabular}


Table A-22. Tank 241-BY-105 Analytical Results: Phosphorus.

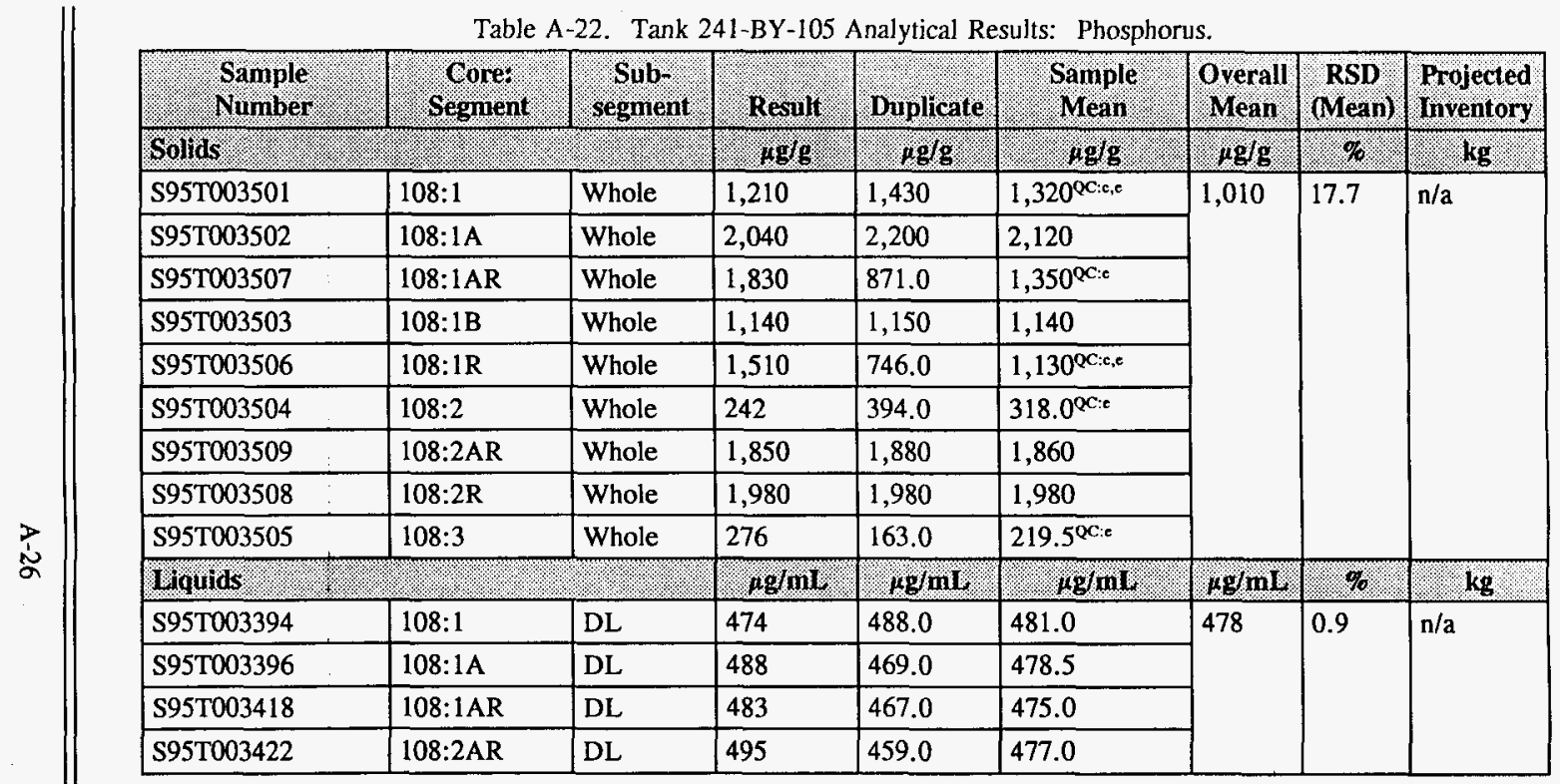


Table A-23. Tank 241-BY-105 Analytical Results: Potassium.

\begin{tabular}{|c|c|c|c|c|c|c|c|c|}
\hline $\begin{array}{l}\text { Sample } \\
\text { Iumber }\end{array}$ & Core: & $\begin{array}{l}\text { Sub- } \\
\text { segnuent }\end{array}$ & Resuilt & Duplicate & $\begin{array}{l}\text { Sample } \\
\text { Mean }\end{array}$ & $\begin{array}{l}\text { Overall } \\
\text { Mean }\end{array}$ & $\begin{array}{c}\text { RSD } \\
\text { (Mean) }\end{array}$ & $\begin{array}{l}\text { Projected } \\
\text { Inventory }\end{array}$ \\
\hline Solids & (15. & & $\mu \mathrm{g} g$ & $\mathrm{\mu g} / \mathrm{g}$ & $.0 \mathrm{~g} / \mathrm{g}$ & $\mu \mathrm{g} / \mathrm{g}$. & (1. 76 & kg \\
\hline S95T003501 & 108:1 & Whole & 646 & 652.0 & 649.0 & \multirow[t]{9}{*}{712} & \multirow[t]{9}{*}{10.7} & \multirow[t]{9}{*}{$\mathrm{n} / \mathrm{a}$} \\
\hline S95T003502 & 108:1A & Whole & 466 & 592.0 & $529.0^{\alpha \mathrm{CC}}$ & & & \\
\hline S95T003507 & 108: $1 \mathrm{AR}$ & Whole & 763 & 1,060 & $911.5^{\mathrm{QC:c}}$ & & & \\
\hline S95T003503 & 108:1B & Whole & 568 & 657.0 & 612.5 & & & \\
\hline S95T003506 & 108:1R & Whole & 760 & 777.0 & 768.5 & & & \\
\hline S95T003504 & $108: 2$ & Whole & 881 & 929.0 & 905.0 & & & \\
\hline S95T003509 & 108:2AR & Whole & 764 & 986.0 & $875.0^{\text {QC:e }}$ & & & \\
\hline S95T003508 & $108: 2 \mathrm{R}$ & Whole & 808 & 842.0 & 825.0 & & & \\
\hline S95T003505 & 108:3 & Whole & 569 & 578.0 & 573.5 & & & \\
\hline \multicolumn{3}{|c|}{ Liguids } & $48 \mathrm{mil}$ & $\mu \mathrm{g} / \mathrm{nL}$ & $1.9 \mathrm{~g} / \mathrm{mI}$ & $1 \mathrm{~g} / \mathrm{ml}$ & $\%$ & $1 . \mathbf{k g}$ \\
\hline S95T003394 & 108:1 & DL & 3,270 & 3,420 & 3,340 & \multirow[t]{4}{*}{3,790} & \multirow[t]{4}{*}{9.9} & \multirow[t]{4}{*}{$n / a$} \\
\hline S95T003396 & 108:1A & $\mathrm{DL}$ & 3,500 & 3,200 & 3,350 & & & \\
\hline S95T003418 & 108:1AR & DL & 3,540 & 3,540 & $3,540^{\mathrm{QC}: \mathrm{c}}$ & & & \\
\hline S95T003422 & 108:2AR & DL & 4,240 & 4,080 & $4,160^{\alpha C: c}$ & & & \\
\hline
\end{tabular}


Table A-24. Tank 241-BY-105 Analytical Results: Samarium.

\begin{tabular}{|c|c|c|c|c|c|c|c|c|}
\hline $\begin{array}{l}\text { Sample } \\
\text { Vumber }\end{array}$ & $\begin{array}{l}\text { Sore: } \\
\text { Segnent }\end{array}$ & sub- & Resull & Duplicate & Sample & Overall & $\begin{array}{l}\mathrm{RSD} \\
\mathrm{Mean})\end{array}$ & $\begin{array}{l}\text { Projected } \\
\text { Inventory }\end{array}$ \\
\hline Solids - & (3) & 4.8 .8 & $29 \mathrm{~g}$ & $.9 \mathrm{~g} / \mathrm{g}$ & $.9 \mathrm{~g} / \mathrm{g}$ & $\mu \mathrm{g} / \mathrm{g}$ & .8 & 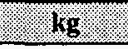 \\
\hline S95T003501 & $108: 1$ & Whole & $<43.20$ & $<39.1$ & $<41.2$ & \multirow[t]{9}{*}{$<40.0$} & \multirow[t]{9}{*}{$n / a$} & \multirow[t]{9}{*}{$\mathrm{n} / \mathrm{a}$} \\
\hline S95T003502 & 108:1A & Whole & $<38.50$ & $<38.9$ & $<38.7$ & & & \\
\hline S95T003507 & 108:1AR & Whole & $<46.70$ & $<45.1$ & $<45.9$ & & & \\
\hline S95T003503 & 108:1B & Whole & $<36.60$ & $<35.6$ & $<36.1$ & & & \\
\hline S95T003506 & 108:1R & Whole & $<35.90$ & $<35.3$ & $<35.6$ & & & \\
\hline S95T003504 & 108:2 & Whole & $<44.30$ & $<46.9$ & $<45.6$ & & & \\
\hline S95T003509 & 108:2AR & Whole & $<36.50$ & $<34.7$ & $<35.6$ & & & \\
\hline S95T003508 & 108:2R & Whole & $<45.60$ & $<47.2$ & $<46.4$ & & & \\
\hline S95T003505 & $108: 3$ & Whole & $<37.30$ & $<38.7$ & $<38.0$ & & & \\
\hline \multicolumn{2}{|l|}{ Liquids: } & (2) & $1,9 / \mathrm{ml}$ & $4 \mathrm{~g} / \mathrm{mi}$ & kg/mi & 18g/nil. & $\%$ & kg. \\
\hline S95T003394 & 108:1 & $\mathrm{DL}$ & $<40.10$ & $<40.1$ & $<40.1$ & \multirow[t]{4}{*}{$<40.1$} & \multirow[t]{4}{*}{$\mathrm{n} / \mathrm{a}$} & \multirow[t]{4}{*}{$n / a$} \\
\hline \$95T003396 & 108:1A & DL & $<40.10$ & $<40.1$ & $<40.1$ & & & \\
\hline S95T003418 & 108:1AR & DL & $<40.10$ & $<40.1$ & $<40.1$ & & & \\
\hline S95T003422 & 108:2AR & $\mathrm{DL}$ & $<40.10$ & $<40.1$ & $<40.1$ & & & \\
\hline
\end{tabular}


Table A-25. Tank 241-BY-105 Analytical Results: Selenium.

\begin{tabular}{|c|c|c|c|c|c|c|c|c|}
\hline $\begin{array}{l}\text { Sample } \\
\text { Number }\end{array}$ & $\begin{array}{l}\text { Core: } \\
\text { Segment }\end{array}$ & $\begin{array}{l}\text { Sub- } \\
\text { segnent }\end{array}$ & Result & Duplicate: & $\begin{array}{l}\text { Sample: } \\
\text { Mean }\end{array}$ & $\begin{array}{c}\text { Overall } \\
\text { Mean }\end{array}$ & $\begin{array}{r}\text { RSD } \\
\text { (Mean) }\end{array}$ & $\begin{array}{l}\text { Projected } \\
\text { Inventory }\end{array}$ \\
\hline Sollds : & 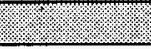 & W. & $\mu \mathrm{g} / \mathrm{g}$ & $n g / g$ & $\mu \mathrm{g} / \mathrm{g}$ & $\mu g / g$ & 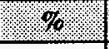 & $1.9 \mathrm{~kg}$. \\
\hline S95T003501 & $108: 1$ & Whole & $<43.20$ & $<39.1$ & $<41.2$ & \multirow[t]{9}{*}{$<40.0$} & \multirow[t]{9}{*}{$n / a$} & \multirow[t]{9}{*}{$\mathrm{n} / \mathrm{a}$} \\
\hline S95T003502 & 108:1A & Whole & $<38.50$ & $<38.9$ & $<38.7$ & & & \\
\hline S95T003507 & 108:1AR & Whole & $<46.70$ & $<45.1$ & $<45.9$ & & & \\
\hline S95T003503 & 108:1B & Whole & $<36.60$ & $<35.6$ & $<36.1$ & & & \\
\hline S95T003506 & 108:1R & Whole & $<35.90$ & $<35.3$ & $<35.6$ & & & \\
\hline S95T003504 & $108: 2$ & Whole & $<44.30$ & $<46.9$ & $<45.6$ & & & \\
\hline S95T003509 & $108: 2 \mathrm{AR}$ & Whole & $<36.50$ & $<34.7$ & $<35.6$ & & & \\
\hline S95T003508 & $108: 2 \mathrm{R}$ & Whole & $<45.60$ & $<47.2$ & $<46.4$ & & & \\
\hline S95T003505 & $108: 3$ & Whole & $<37.30$ & $<38.7$ & $<38.0$ & & & \\
\hline Liquias & 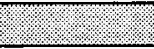 & (2) & pg/mi. & $1 \mathrm{~g} / \mathrm{nI}$ & $1 \mathrm{~g} / \mathrm{mL}$ & $\mu \mathrm{g} / \mathrm{mI}$ & $9 \%$ & 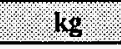 \\
\hline S95T003394 & $108: 1$ & DL & $<40.10$ & $<40.1$ & $<40.1$ & \multirow[t]{4}{*}{$<40.1$} & \multirow[t]{4}{*}{$\mathrm{n} / \mathrm{a}$} & \multirow[t]{4}{*}{$n / a$} \\
\hline S95T003396 & $108: 1 \mathrm{~A}$ & DL & $<40.10$ & $<40.1$ & $<40.1$ & & & \\
\hline S95T003418 & 108:1AR & $\mathrm{DL}$ & $<40.10$ & $<40.1$ & $<40.1$ & & & \\
\hline S95T003422 & 108:2AR & DL & $<40.10$ & $<40.1$ & $<40.1$ & & & \\
\hline
\end{tabular}


Table A-26. Tank 241-BY-105 Analytical Results: Silicon.

\begin{tabular}{|c|c|c|c|c|c|c|c|c|}
\hline Sample & Sorct & Subgrient & Result & Buplicate & Sample & $\begin{array}{l}\text { Overall } \\
\text { Meail }\end{array}$ & $\begin{array}{l}\text { RSD } \\
(\text { Mean })\end{array}$ & $\begin{array}{l}\text { Projected } \\
\text { Inventory }\end{array}$ \\
\hline Sollds & 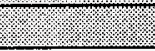 & . & $140 / 9$ & $(. \mu g / \mathrm{g}$. & 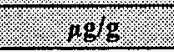 & $\mu \mathrm{g} g$ & \% $\%$ & $.6 \mathrm{~kg}$. \\
\hline S95T003501 & 108:1 & Whole & 201 & 249.0 & $225.0^{\mathrm{QC}: b, c, e}$ & \multirow[t]{9}{*}{180} & \multirow[t]{9}{*}{12.4} & \multirow[t]{9}{*}{$n / a$} \\
\hline S95T003502 & 108:1A & Whole & 322 & 316.0 & $319.0^{\alpha \mathrm{C}: \mathrm{b}}$ & & & \\
\hline S95T003507 & 108:1AR & Whole & 167 & 233.0 & $200.0^{\mathrm{QC}: b, c}$ & & & \\
\hline S95T003503 & $108: 1 \mathrm{~B}$ & Whole & 216 & 262.0 & $239.0^{\alpha \mathrm{C}: \mathrm{b}}$ & & & \\
\hline S95T003506 & 108:1R & Whole & 120 & 246.0 & $183.0^{\mathrm{QC}: b, c}$ & & & \\
\hline S95T003504 & $108: 2$ & Whole & 132 & 221.0 & $176.5^{Q \mathrm{QCb}, c}$ & & & \\
\hline S95T003509 & 108:2AR & Whole & 140 & 156.0 & $148.0^{\mathrm{QC}: \mathrm{b}}$ & & & \\
\hline S95T003508 & 108:2R & \begin{tabular}{|l|} 
Whole \\
\end{tabular} & 374 & 298.0 & $336.0^{\alpha C: b, c}$ & & & \\
\hline S95T003505 & $108: 3$ & Whole & 74.90 & 98.70 & $86.80^{Q \mathrm{QC:bec}}$ & & & \\
\hline Wougs & 2.7. & & $\mu \mathrm{gnL}$ & $48 / \mathrm{ml}$ & $1 \mathrm{~g} / \mathrm{ml}$ & $\mathrm{xg} / \mathrm{m}$ & .9 & . 68 \\
\hline S95T003394 & 108:1 & DL & 149 & 152.0 & 150.5 & \multirow[t]{4}{*}{144} & \multirow[t]{4}{*}{23.6} & \multirow[t]{4}{*}{$n / a$} \\
\hline S95T003396 & 108:1A & DL & 306 & 239.0 & $272.5^{\mathrm{QC}: e}$ & & & \\
\hline S95T003418 & 108:1AR & $\mathrm{DL}$ & 144 & 139.0 & 141.5 & & & \\
\hline S95T003422 & 108:2AR & DL & 97.80 & 103.0 & 100.4 & & & \\
\hline
\end{tabular}


Table A-27. Tank 241-BY-105 Analytical Results: Silver.

\begin{tabular}{|c|c|c|c|c|c|c|c|c|}
\hline $\begin{array}{l}\text { Sample: } \\
\text { Number }\end{array}$ & . Sorer & sub & Resuir & Duplicate & Sample & Overall & $\begin{array}{l}\text { RSD } \\
\text { (Mean) }\end{array}$ & $\begin{array}{l}\text { Projected } \\
\text { Inventory }\end{array}$ \\
\hline Sollos & 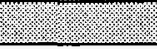 & & $4 \mathrm{~g} / \mathrm{g}$ & $1 \mathrm{mg/g}$ & $.1 \mathrm{~g} / \mathrm{g}$ & $10 \mathrm{~g} / \mathrm{g}$ & $\% \%$ & $\mathrm{~kg}_{\mathrm{g}}$ \\
\hline S95T003501 & 108:1 & Whole & 13.10 & 14.10 & 13.60 & \multirow[t]{9}{*}{17.4} & \multirow[t]{9}{*}{8.6} & \multirow[t]{9}{*}{$\mathrm{n} / \mathrm{a}$} \\
\hline S95T003502 & 108:1A & Whole & 14.30 & 14.40 & 14.35 & & & \\
\hline S95T003507 & 108:1AR & Whole & 14.30 & 15.50 & 14.90 & & & \\
\hline S95T003503 & 108:1B & Whole & 14.60 & 15.80 & 15.20 & & & \\
\hline S95T003506 & $108: 1 \mathrm{R}$ & Whole & 14.90 & 16.80 & 15.85 & & & \\
\hline \$95T003504 & $108: 2$ & Whole & 20.60 & 22.20 & 21.40 & & & \\
\hline S95T003509 & $108: 2 \mathrm{AR}$ & Whole & 13.00 & 14.10 & 13.55 & & & \\
\hline S95T003508 & $108: 2 \mathrm{R}$ & Whole & 14.90 & 15.50 & 15.20 & & & \\
\hline \$95T003505 & $108: 3$ & Whole & 13.50 & 27.70 & $20.60^{\mathrm{QC:e}}$ & & & \\
\hline \multicolumn{3}{|l|}{ Liquids } & $\mu \mathrm{g} / \mathrm{mL}$ & $\mu \mathrm{g} / \mathrm{ml}^{\prime}$ & $1 / \mathrm{g} / \mathrm{ml}$ & $19 / \mathrm{ml}$ & ( & k8 \\
\hline S95T003394 & 108:1 & DL & $<4.010$ & $<4.01$ & $<4.01^{Q C: c}$ & \multirow[t]{4}{*}{$<4.01$} & \multirow[t]{4}{*}{$n / a$} & \multirow[t]{4}{*}{$\mathrm{n} / \mathrm{a}$} \\
\hline S95T003396 & $108: 1 \mathrm{~A}$ & $\mathrm{DL}$ & $<4.010$ & $<4.01$ & $<4.01^{\mathrm{QC:c}}$ & & & \\
\hline S95T003418 & 108:1AR & $\mathrm{DL}$ & $<4.010$ & $<4.01$ & $<4.01^{\mathrm{QC}: \mathrm{c}}$ & & & \\
\hline S95T003422 & 108:2AR & DL & $<4.010$ & $<4.01$ & $<4.01^{\mathrm{QC}: \mathrm{c}}$ & & & \\
\hline
\end{tabular}




\begin{tabular}{|c|c|c|c|c|c|c|c|c|}
\hline $\begin{array}{c}\text { Sample } \\
\text { Number } \\
\end{array}$ & $\begin{array}{l}\text { Core: } \\
\text { Segment } \\
\end{array}$ & $\begin{array}{l}\text { Sub- } \\
\text { segment }\end{array}$ & Result & Duplicate & $\begin{array}{l}\text { Sample } \\
\text { Nean } \\
\end{array}$ & $\begin{array}{l}\text { Overall } \\
\text { Mean }\end{array}$ & $\begin{array}{c}\text { RSD } \\
\text { (Mean) }\end{array}$ & \begin{tabular}{|l|} 
Projected \\
Inventory \\
\end{tabular} \\
\hline Solids: & 4.8 & 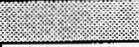 & $4 \mathrm{~g} / \mathrm{g}$ & agtg & $14 \mathrm{~g} / \mathrm{g}$ & $1.8 / \mathrm{g}$ & 9. & $1 \mathrm{~kg}$ \\
\hline S95T003501 & $108: 1$ & Whole & $1.89 \mathrm{E}+05$ & $1.85 \mathrm{E}+05$ & $1.87 \mathrm{E}+05^{\mathrm{QC}: \mathrm{d}}$ & \multirow[t]{9}{*}{$1.98 \mathrm{E}+05$} & \multirow[t]{9}{*}{2.7} & \multirow[t]{9}{*}{$n / a$} \\
\hline S95T003502 & 108:1A & Whole & $1.84 \mathrm{E}+05$ & $1.84 \mathrm{E}+05$ & $1.84 \mathrm{E}+05$ & & & \\
\hline S95T003507 & 108:1AR & Whole & $1.83 \mathrm{E}+05$ & $1.92 \mathrm{E}+05$ & $1.88 \mathrm{E}+05$ & & & \\
\hline S95T003503 & 108:1B & Whole & $1.92 \mathrm{E}+05$ & $1.98 \mathrm{E}+05$ & $1.95 \mathrm{E}+05$ & & & \\
\hline S95T003506 & 108:1R & Whole & $1.97 \mathrm{E}+05$ & $2.19 \mathrm{E}+05$ & $2.08 \mathrm{E}+05^{\mathrm{OC}: \mathrm{d}, \mathrm{c}}$ & & & \\
\hline S95T003504 & $108: 2$ & \begin{tabular}{|l|} 
Whole \\
\end{tabular} & $2.13 \mathrm{E}+05$ & $2.36 \mathrm{E}+05$ & $2.24 \mathrm{E}+05^{Q \mathrm{C}: \mathrm{e}}$ & & & \\
\hline S95T003509 & 108:2AR & Whole & $1.64 \mathrm{E}+05$ & $1.79 \mathrm{E}+05$ & $1.72 \mathrm{E}+05$ & & & \\
\hline S95T003508 & 108:2R & Whole & $1.81 \mathrm{E}+05$ & $1.97 \mathrm{E}+05$ & $1.89 \mathrm{E}+05$ & & & \\
\hline S95T003505 & $108: 3$ & Whole & $1.82 \mathrm{E}+05$ & $2.29 \mathrm{E}+05$ & $2.06 \mathrm{E}+05^{\mathrm{QC}: \mathrm{e}}$ & & & \\
\hline \multicolumn{3}{|c|}{ Eiguids : } & $19 / \mathbf{m i l}$ & ( $\mu \mathrm{g} / \mathrm{mil}$ & $1.1 .9 \mathrm{~g} / \mathrm{ml}$ & $1.1 \mathrm{~g} / \mathrm{mi}$ & $\%$ & (2.58 \\
\hline S95T003394 & 108:1 & $\mathrm{DL}$ & $1.94 \mathrm{E}+05$ & $1.98 \mathrm{E}+05$ & $1.96 \mathrm{E}+05$ & \multirow[t]{4}{*}{$2.03 \mathrm{E}+05$} & \multirow[t]{4}{*}{2.5} & \multirow[t]{4}{*}{$n / a$} \\
\hline S95T003396 & $108: 1 \mathrm{~A}$ & DL & $2.04 \mathrm{E}+05$ & $1.96 \mathrm{E}+05$ & $2.00 \mathrm{E}+05$ & & & \\
\hline S95T003418 & 108:1AR & $\mathrm{DL}$ & $1.99 \mathrm{E}+05$ & $1.97 \mathrm{E}+05$ & $1.98 \mathrm{E}+05$ & & & \\
\hline S95T003422 & 108:2AR & DL & $2.12 \mathrm{E}+05$ & $2.04 \mathrm{E}+05$ & $2.08 \mathrm{E}+05$ & & & \\
\hline
\end{tabular}


Table A-29. Tank 241-BY-105 Analytical Results: Strontium.

\begin{tabular}{|c|c|c|c|c|c|c|c|c|}
\hline Sample & Segret & sub. & Resull & Duplicate & $\begin{array}{l}\text { Sample } \\
\text { Mean }\end{array}$ & $\begin{array}{l}\text { Overall } \\
\text { Mean }\end{array}$ & $\begin{array}{c}\text { RSD } \\
\text { (Mean) }\end{array}$ & $\begin{array}{l}\text { Projected } \\
\text { Inventory }\end{array}$ \\
\hline Solids & & 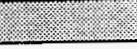 & $\mu g / g$ & $4 \mathrm{glg}$ & $.4 \mathrm{gg}$ & 1.98 & 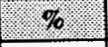 & $.1 \mathrm{~kg}$. \\
\hline S95T003501 & 108:1 & Whole & 74.60 & 81.10 & 77.85 & \multirow[t]{9}{*}{88.3} & \multirow[t]{9}{*}{13.2} & \multirow[t]{9}{*}{$n / a$} \\
\hline S95T003502 & 108:1A & Whole & 127 & 127.0 & 127.0 & & & \\
\hline S95T003507 & 108:1AR & Whole & 59.40 & 85.70 & $72.55^{\mathrm{QC}: \mathrm{e}}$ & & & \\
\hline S95T003503 & 108:1B & Whole & 137 & 137.0 & 137.0 & & & \\
\hline S95T003506 & 108:1R & Whole & 73.00 & 100.0 & $86.50^{\circ \mathrm{C}: \mathrm{e}}$ & & & \\
\hline S95T003504 & $108: 2$ & Whole & 28.00 & 30.30 & 29.15 & & & \\
\hline S95T003509 & 108:2AR & Whole & 127 & 118.0 & 122.5 & & & \\
\hline \$95T003508 & 108:2R & Whole & 133 & 147.0 & 140.0 & & & \\
\hline \$95T003505 & $108: 3$ & Whole & 31.20 & 104.0 & $67.60^{\alpha C: c}$ & & & \\
\hline Grouids & (9: : & 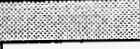 & $\mu \mathrm{griI}$ & $0 \mathrm{~g} / \mathrm{ml}$. & $(1 / \mathrm{g} / \mathrm{mL}$ & $\mu \mathrm{g} / \mathrm{ml}$ & $1.6 \%$ & $.1 \mathrm{~kg}$ \\
\hline S95T003394 & 108: 1 & $\mathrm{DL}$ & $<4.010$ & $<4.01$ & $<4.01$ & \multirow[t]{4}{*}{$<4.01$} & \multirow[t]{4}{*}{$n / a$} & \multirow[t]{4}{*}{$n / a$} \\
\hline S95T003396 & 108:1A & DL & $<4.010$ & $<4.01$ & $<4.01$ & & & \\
\hline S95T003418 & 108:1AR & DL & $<4.010$ & $<4.01$ & $<4.01$ & & & \\
\hline S95T003422 & 108:2AR & DL & $<4.010$ & $<4.01$ & $<4.01$ & & & \\
\hline
\end{tabular}


Table A-30. Tank 241-BY-105 Analytical Results: Sulfur.

\begin{tabular}{|c|c|c|c|c|c|c|c|c|}
\hline $\begin{array}{l}\text { Sample } \\
\text { Number }\end{array}$ & $\begin{array}{l}\text { Core: } \\
\text { Segment }\end{array}$ & $\begin{array}{l}\text { Sub } \\
\text { segment }\end{array}$ & Result & Duplicate & Sample & $\begin{array}{l}\text { Overall } \\
\text { Mean }\end{array}$ & $\begin{array}{l}\text { RSD } \\
\text { (Mean) }\end{array}$ & $\begin{array}{l}\text { Projected } \\
\text { Inventory }\end{array}$ \\
\hline Solds & 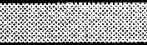 & . & $\mu \mathrm{g} / \mathrm{g}$ & $\mu \mathrm{glg}$ & $\mu g / g$ & $14 \mathrm{gg}$ & $1 \%$ & $\mathrm{~kg}$ \\
\hline S95T003501 & 108:1 & Whole & 2,670 & 3,010 & 2,840 & \multirow[t]{9}{*}{3,140} & \multirow[t]{9}{*}{30.6} & \multirow[t]{9}{*}{$n / a$} \\
\hline S95T003502 & 108:1A & Whole & 5,080 & 5,140 & 5,110 & & & \\
\hline \$95T003507 & 108:1AR & Whole & 1,930 & 2,860 & $2,400^{\text {QC:e }}$ & & & \\
\hline S95T003503 & 108:1B & Whole & 3,150 & 3,370 & 3,260 & & & \\
\hline S95T003506 & 108:1R & Whole & 3,600 & 4,570 & $4,080^{\mathrm{QC}: d, e}$ & & & \\
\hline S95T003504 & 108:2 & Whole & 4,510 & 4,930 & 4,720 & & & \\
\hline S95T003509 & 108:2AR & Whole & 4,470 & 4,620 & 4,540 & & & \\
\hline S95T003508 & $108: 2 \mathrm{R}$ & Whole & 5,170 & 4,790 & 4,980 & & & \\
\hline S95T003505 & $108: 3$ & Whole & 442 & 1,840 & $1,140^{\mathrm{OC}: \mathrm{e}}$ & & & \\
\hline \multicolumn{3}{|l|}{ Ligulds } & $\mu \mathrm{glm}$ & 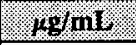 & ng/nil & & $.7 \%$ & .1 .69 \\
\hline S95T003394 & 108:1 & DL & 647 & 676.0 & 661.5 & \multirow[t]{4}{*}{675} & \multirow[t]{4}{*}{1.1} & \multirow[t]{4}{*}{$\mathrm{n} / \mathrm{a}$} \\
\hline S95T003396 & 108:1A & DL & 697 & 661.0 & 679.0 & & & \\
\hline S95T003418 & 108:1AR & $\mathrm{DL}$ & 702 & 690.0 & 696.0 & & & \\
\hline S95T003422 & 108:2AR & DL & 689 & 655.0 & 672.0 & & & \\
\hline
\end{tabular}


Table A-31. Tank 241-BY-105 Analytical Results: Thallium.

\begin{tabular}{|c|c|c|c|c|c|c|c|c|}
\hline . Sample & $\begin{array}{l}\text { Coret } \\
\text { Segnent } \\
\end{array}$ & $\begin{array}{l}\text { Sub: } \\
\text { segment }\end{array}$ & Result & Duplicate & $\begin{array}{l}\text { Sample } \\
\text { Mean }\end{array}$ & $\begin{array}{c}\text { Overall } \\
\text { Mean }\end{array}$ & $\begin{array}{c}\text { RSD } \\
\text { (Mean) } \\
\end{array}$ & $\begin{array}{l}\text { Projected } \\
\text { Inventory }\end{array}$ \\
\hline Sollas & 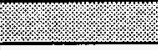 & 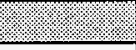 & $\mu \mathrm{g} / \mathrm{g}$ & $\mu \mathrm{gg} / \mathrm{g}$ & $\mathrm{ag} / \mathrm{g}$ & $\pi \mathrm{g} / \mathrm{g}$ & $\%$ & (ng. \\
\hline S95T003501 & $108: 1$ & Whole & $<86.50$ & $<78.3$ & $<82.4$ & \multirow[t]{9}{*}{$<80.0$} & \multirow[t]{9}{*}{$n / a$} & \multirow[t]{9}{*}{$n / a$} \\
\hline S95T003502 & 108:1A & Whole & $<76.90$ & $<77.7$ & $<77.3$ & & & \\
\hline S95T003507 & 108:1AR & Whole & $<93.40$ & $<90.3$ & $<91.9$ & & & \\
\hline S95T003503 & $108: 1 \mathrm{~B}$ & Whole & $<73.20$ & $<71.2$ & $<72.2$ & & & \\
\hline S95T003506 & 108:1R & Whole & $<71.70$ & $<70.6$ & $<71.2$ & & & \\
\hline S95T003504 & $108: 2$ & Whole & $<88.50$ & $<93.9$ & $<91.2$ & & & \\
\hline S95T003509 & 108:2AR & Whole & $<73.00$ & $<69.3$ & $<71.2$ & & & \\
\hline S95T003508 & \begin{tabular}{|l|}
$108: 2 \mathrm{R}$ \\
\end{tabular} & Whole & $<91.20$ & $<94.5$ & $<92.9$ & & & \\
\hline \begin{tabular}{|l|} 
S95T003505 \\
\end{tabular} & $108: 3$ & Whole & $<74.50$ & $<77.5$ & $<76.0$ & & & \\
\hline \multicolumn{3}{|c|}{ Miquias } & $48 / \mathrm{ml}$. & rg/mil. & $1 / \mathrm{g} / \mathrm{ml}$ & $\mu \mathrm{g} / \mathrm{ml}$ & 9. & kg. \\
\hline \$95T003394 & $108: 1$ & $\mathrm{DL}$ & $<80.20$ & $<80.2$ & $<80.2$ & \multirow[t]{4}{*}{$<80.2$} & \multirow[t]{4}{*}{$\mathrm{n} / \mathrm{a}$} & \multirow[t]{4}{*}{$\mathrm{n} / \mathrm{a}$} \\
\hline S95T003396 & $108: 1 \mathrm{~A}$ & $\mathrm{DL}$ & $<80.20$ & $<80.2$ & $<80.2$ & & & \\
\hline S95T003418 & 108:1AR & $\mathrm{DL}$ & $<80.20$ & $<80.2$ & $<80.2$ & & & \\
\hline S95T003422 & 108:2AR & $\mathrm{DL}$ & $<80.20$ & $<80.2$ & $<80.2$ & & & \\
\hline
\end{tabular}


Table A-32. Tank 241-BY-105 Analytical Results: Titanium.

\begin{tabular}{|c|c|c|c|c|c|c|c|c|}
\hline Sample & Soret & $\begin{array}{l}\text { Sub- } \\
\text { segment }\end{array}$ & Result & Duplicate & $\begin{array}{l}\text { Sample } \\
\text { Mean }\end{array}$ & $\begin{array}{l}\text { Overall } \\
\text { Mean }\end{array}$ & $\begin{array}{c}\text { RSD } \\
\text { (Mean) }\end{array}$ & $\begin{array}{l}\text { Projected } \\
\text { Inventory }\end{array}$ \\
\hline Solids & 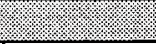 & (2) & 1996 & $\mathrm{pg}_{\mathrm{g}}$ & $\mu \mathrm{g} / \mathrm{g}$ & $r \mathrm{~g} / \mathrm{g}$ & 8 & $\mathrm{~kg}$ \\
\hline \$95T003501 & 108:1 & Whole & $<4.320$ & $<3.91$ & $<4.12$ & \multirow[t]{9}{*}{$<4.00$} & \multirow[t]{9}{*}{$n / a$} & \multirow[t]{9}{*}{$\mathrm{n} / \mathrm{a}$} \\
\hline S95T003502 & 108:1A & Whole & $<3.850$ & $<3.89$ & $<3.87$ & & & \\
\hline S95T003507 & 108:1AR & Whole & $<4.670$ & $<4.51$ & $<4.59$ & & & \\
\hline S95T003503 & 108:1B & Whole & $<3.660$ & $<3.56$ & $<3.61$ & & & \\
\hline S95T003506 & 108:1R & Whole & $<3.590$ & $<3.53$ & $<3.56$ & & & \\
\hline S95T003504 & $108: 2$ & Whole & $<4.430$ & $<4.69$ & $<4.56$ & & & \\
\hline S95T003509 & 108:2AR & Whole & $<3.650$ & $<3.47$ & $<3.56$ & & & \\
\hline S95T003508 & $108: 2 \mathrm{R}$ & Whole & $<4.560$ & $<4.72$ & $<4.64$ & & & \\
\hline S95T003505 & $108: 3$ & Whole & $<3.730$ & $<3.87$ & $<3.80$ & & & \\
\hline \multicolumn{2}{|l|}{ Viquids } & & $19 \mathrm{ml}$ & $\mu \mathrm{g} / \mathrm{mi}$ & $1 \mathrm{~g} / \mathrm{ml}$ & $\mu \mathrm{g} / \mathrm{ml}$ &.$\%$ & $\mathbf{k g}$ \\
\hline S95T003394 & 108:1 & DL & $<4.010$ & $<4.01$ & $<4.01$ & \multirow[t]{4}{*}{$<4.01$} & \multirow[t]{4}{*}{$\mathrm{n} / \mathrm{a}$} & \multirow[t]{4}{*}{$n / a$} \\
\hline S95T003396 & 108:1A & DL & $<4.010$ & $<4.01$ & $<4.01$ & & & \\
\hline S95T003418 & 108:1AR & DL & $<4.010$ & $<4.01$ & $<4.01$ & & & \\
\hline S95T003422 & 108:2AR & DL & $<4.010$ & $<4.01$ & $<4.01$ & & & \\
\hline
\end{tabular}


Table A-33. Tank 241-BY-105 Analytical Results: Uranium.

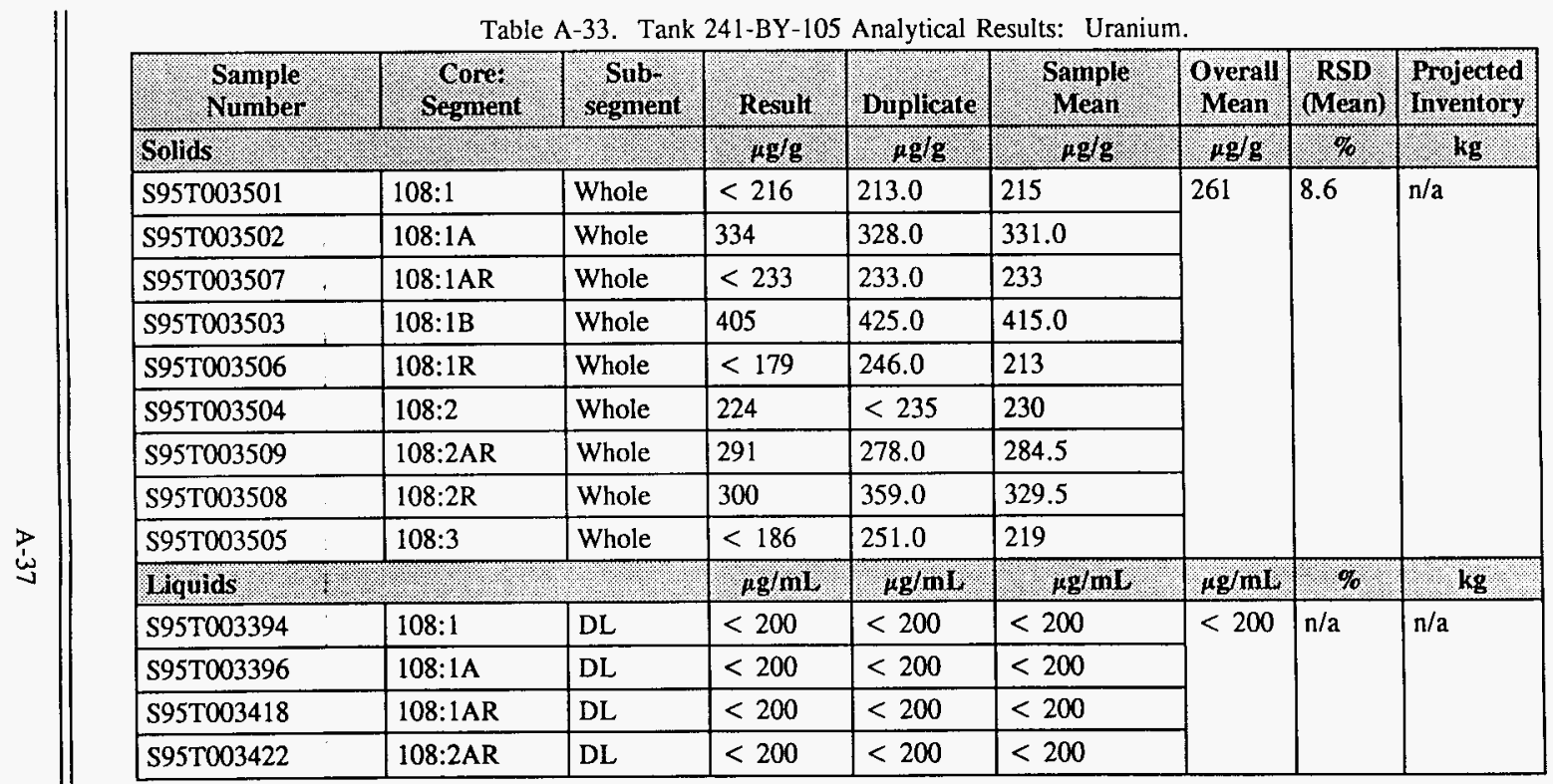


Table A-34. Tank 241-BY-105 Analytical Results: Vanadium.

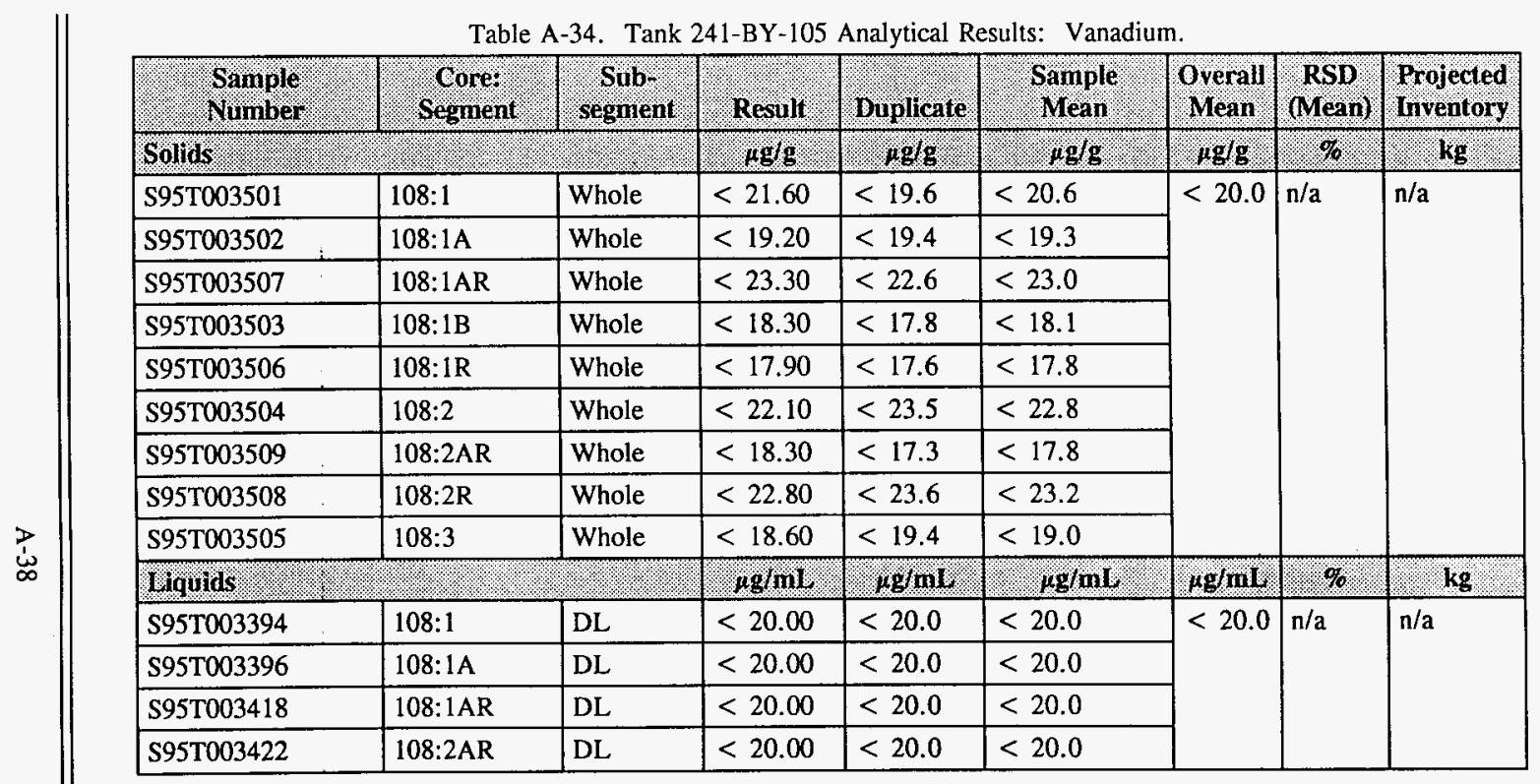


Table A-35. Tank 241-BY-105 Analytical Results: Zinc.

\begin{tabular}{|c|c|c|c|c|c|c|c|c|}
\hline Sample & $\begin{array}{l}\text { Core: } \\
\text { Segment }\end{array}$ & $\begin{array}{l}\text { sub- } \\
\text { segnient }\end{array}$ & Result & Duplicate & $\begin{array}{l}\text { Sample } \\
\text { Mean }\end{array}$ & $\begin{array}{l}\text { Overall } \\
\text { Mean }\end{array}$ & $\begin{array}{l}\text { RSD } \\
\text { (Mean) }\end{array}$ & $\begin{array}{l}\text { Projected } \\
\text { Inventory }\end{array}$ \\
\hline Solids. & 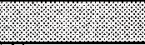 & (2. & rg/g. & og/g & $\mu \mathrm{g} / \mathrm{g}$ & $1 / \mathrm{g} / \mathrm{g}$ & $\%$ & $\mathrm{~kg}$ \\
\hline S95T003501 & 108:1 & Whole & 25.20 & 28.20 & 26.70 & \multirow[t]{9}{*}{36.8} & \multirow[t]{9}{*}{22.6} & \multirow[t]{9}{*}{$n / a$} \\
\hline S95T003502 & 108:1A & Whole & 43.40 & 39.30 & 41.35 & & & \\
\hline S95T003507 & 108:1AR & Whole & 39.40 & 51.90 & $45.65^{\mathrm{OC} e \mathrm{e}}$ & & & \\
\hline S95T003503 & 108:1B & Whole & 34.00 & 30.60 & 32.30 & & & \\
\hline S95T003506 & 108:1R & Whole & 46.10 & 57.90 & $52.00^{\mathrm{QC:e}}$ & & & \\
\hline S95T003504 & $108: 2$ & Whole & 29.70 & 19.20 & $24.45^{\mathrm{QC}: t}$ & & & \\
\hline S95T003509 & $108: 2 \mathrm{AR}$ & Whole & 81.90 & 62.00 & $71.95^{\mathrm{QC}: \mathrm{e}}$ & & & \\
\hline S95T003508 & $108: 2 \mathrm{R}$ & Whole & 65.80 & 78.30 & 72.05 & & & \\
\hline S95T003505 & $108: 3$ & Whole & 12.80 & 16.60 & $14.70^{\text {QC:e }}$ & & & \\
\hline \multicolumn{3}{|l|}{ Kiquids } & ng/nil. & $\mathrm{gg}_{\mathrm{ml}}$ & $18 / \mathrm{mL}$ & (kg/ml. & $\%$ & kg. \\
\hline S95T003394 & 108:1 & DL & 26.60 & 31.80 & 29.20 & \multirow[t]{4}{*}{63.5} & \multirow[t]{4}{*}{37.2} & \multirow[t]{4}{*}{$\mathrm{n} / \mathrm{a}$} \\
\hline S95T003396 & 108:1A & DL & 98.50 & 107.0 & 102.8 & & & \\
\hline S95T003418 & 108:1AR & DL & 151 & 150.0 & 150.5 & & & \\
\hline S95T003422 & 108:2AR & DL & 33.40 & 32.20 & 32.80 & & & \\
\hline
\end{tabular}


Table A-36. Tank 241-BY-105 Analytical Results: Zirconium.

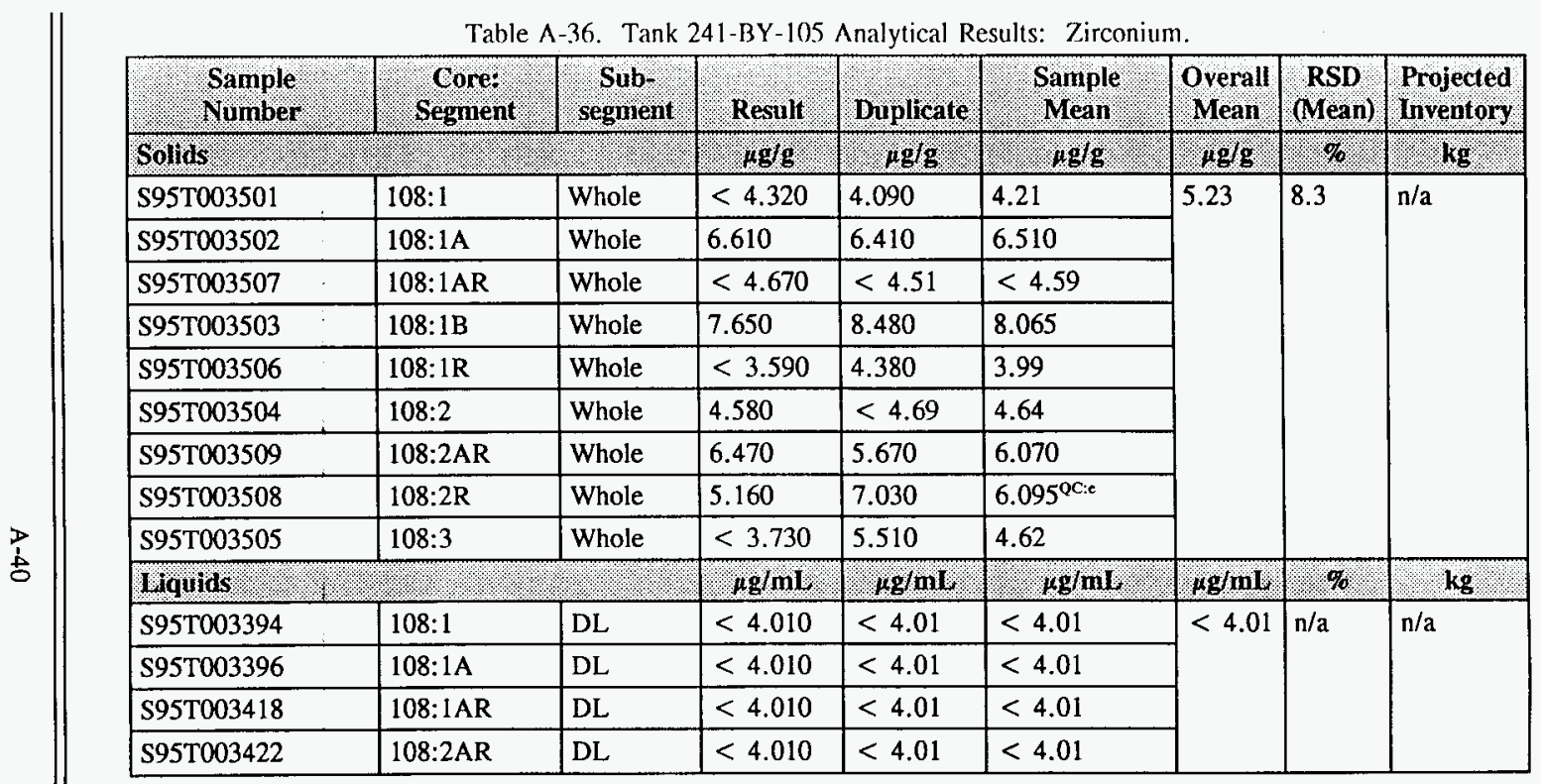


Table A-37. Tank 241-BY-105 Analytical Results: Chloride.

\begin{tabular}{|c|c|c|c|c|c|c|c|c|}
\hline $\begin{array}{l}\text { Sample } \\
\text { Number }\end{array}$ & $\begin{array}{l}\text { Core? } \\
\text { Segment }\end{array}$ & $\begin{array}{l}\text { Sub- } \\
\text { segnient }\end{array}$ & Result & Duplicate & $\begin{array}{l}\text { Sample } \\
\text { Mean }\end{array}$ & $\begin{array}{c}\text { Overall } \\
\text { Mean }\end{array}$ & $\begin{array}{c}\text { RSD } \\
\text { (Mean) }\end{array}$ & $\begin{array}{l}\text { Projected } \\
\text { Inventory }\end{array}$ \\
\hline Solids & $\sqrt{1.12}$ & (1): & $\mu g / g$ & ug/g & $. \mu \mathrm{g} / \mathrm{g}$ & $\mu \mathrm{g} / \mathrm{s}$ & 8. & $\mathrm{~kg}$ \\
\hline S95T003510 & 108:1 & Whole & 530 & 791.0 & $660.8^{\text {OC: } d, e}$ & \multirow[t]{9}{*}{897} & \multirow[t]{9}{*}{30.7} & \multirow[t]{9}{*}{$\mathrm{n} / \mathrm{a}$} \\
\hline S95T003511 & 108:1A & Whole & 428 & 392.0 & \begin{tabular}{|l|}
410.1 \\
\end{tabular} & & & \\
\hline S95T003516 & 108:1AR & Whole & 891 & 1,060 & 975.4 & & & \\
\hline S95T003512 & 108:1B & Whole & 840 & 504.0 & $672.0^{\varphi \mathrm{C}: \mathrm{e}}$ & & & \\
\hline S95T003515 & 108:1R & Whole & 617 & 717.0 & 667.1 & & & \\
\hline S95T003513 & $108: 2$ & Whole & 1,240 & 848.0 & $1,040^{Q \subset: c}$ & & & \\
\hline S95T003518 & 108:2AR & Whole & 2,910 & 1,100 & $2,010^{\mathrm{QC}: e}$ & & & \\
\hline S95T003517 & $108: 2 \mathrm{R}$ & Whole & 1,330 & 1,270 & 1,300 & & & \\
\hline S95T003514 & $108: 3$ & Whole & 551 & 580.0 & 565.4 & & & \\
\hline \multicolumn{3}{|c|}{ Liquids } & $1 \mathrm{~g} / \mathrm{ml}$ & $\mu g / \mathrm{mL}$ & $18 \mathrm{~g} / \mathrm{mL}$ & $\mu g / \operatorname{mil}$ & $1 \%$ & $.1 \mathrm{~kg}$ \\
\hline S95T003394 & $108: 1$ & DL & 3,080 & 3,210 & 3,140 & \multirow[t]{4}{*}{3,660} & \multirow[t]{4}{*}{8.4} & \multirow[t]{4}{*}{$n / a$} \\
\hline S95T003396 & 108:1A & $\mathrm{DL}$ & 3,060 & 3,410 & 3,240 & & & \\
\hline S95T003418 & 108:1AR & $\mathrm{DL}$ & 3,280 & 4,070 & $3,680^{\mathrm{oC}: e}$ & & & \\
\hline S95T003422 & 108:2AR & $\mathrm{DL}$ & 3,940 & 3,990 & 3,960 & & & \\
\hline
\end{tabular}


Table A-38. Tank 241-BY-105 Analytical Results: Flouride.

\begin{tabular}{|c|c|c|c|c|c|c|c|c|}
\hline . 1. Sanple & Sore: & segnient & Result & Duplicate & $\begin{array}{l}\text { Sample } \\
\text { Mean }\end{array}$ & $\begin{array}{l}\text { Overall } \\
\text { Mean }\end{array}$ & $\begin{array}{c}\text { RSD } \\
\text { (Mean) }\end{array}$ & $\begin{array}{l}\text { Projected } \\
\text { Inventory }\end{array}$ \\
\hline Solids & (1.7. & 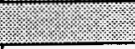 & $1 / 4 g / g$ & $\mu \mathrm{g} / \mathrm{g}$. & $1.4 \mathrm{~g} / \mathrm{g}$ & $14 \mathrm{~g} g$ & $\%$ & $.4 \mathrm{~kg}$. \\
\hline S95T003510 & 108:1 & Whole & 5,420 & 5,630 & 5,520 & \multirow[t]{9}{*}{4,100} & \multirow[t]{9}{*}{29.6} & \multirow[t]{9}{*}{$n / a$} \\
\hline S95T003511 & 108:1A & Whole & 9,490 & 9,970 & 9,730 & & & \\
\hline S95T003516 & 108:1AR & Whole & 3,490 & 4,170 & 3,830 & & & \\
\hline S95T003512 & 108:1B & Whole & 4,510 & 3,930 & 4,220 & & & \\
\hline S95T003515 & 108:1R & Whole & 6,810 & 7,240 & 7,020 & & & \\
\hline S95T003513 & 108:2 & Whole & 3,680 & 3,770 & 3,730 & & & \\
\hline S95T003518 & 108:2AR & Whole & 4,390 & 6,730 & $5,560^{\mathrm{OC}: \mathrm{e}}$ & & & \\
\hline \$95T003517 & $108: 2 \mathrm{R}$ & Whole & 7,690 & 8,850 & 8,270 & & & \\
\hline S95T003514 & $108: 3$ & Whole & 391 & 356.0 & 373.6 & & & \\
\hline \multicolumn{3}{|l|}{ Hiquds } & $.48 / \mathrm{nl}$ & $4 \mathrm{glni}$ & $1, \mathrm{~g} / \mathrm{mL}$ & gg/mi & 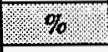 & 1.68 \\
\hline \$95T003394 & 108:1 & $\mathrm{DL}$ & 602 & 648.0 & 624.9 & \multirow[t]{4}{*}{534} & \multirow[t]{4}{*}{13.5} & \multirow[t]{4}{*}{$n / a$} \\
\hline S95T003396 & 108:1A & $\mathrm{DL}$ & 632 & 630.0 & 630.9 & & & \\
\hline S95T003418 & 108:1AR & $\mathrm{DL}$ & 513 & 615.0 & 564.0 & & & \\
\hline S95T003422 & $108: 2 \mathrm{AR}$ & DL & 466 & 457.0 & 461.4 & & & \\
\hline
\end{tabular}




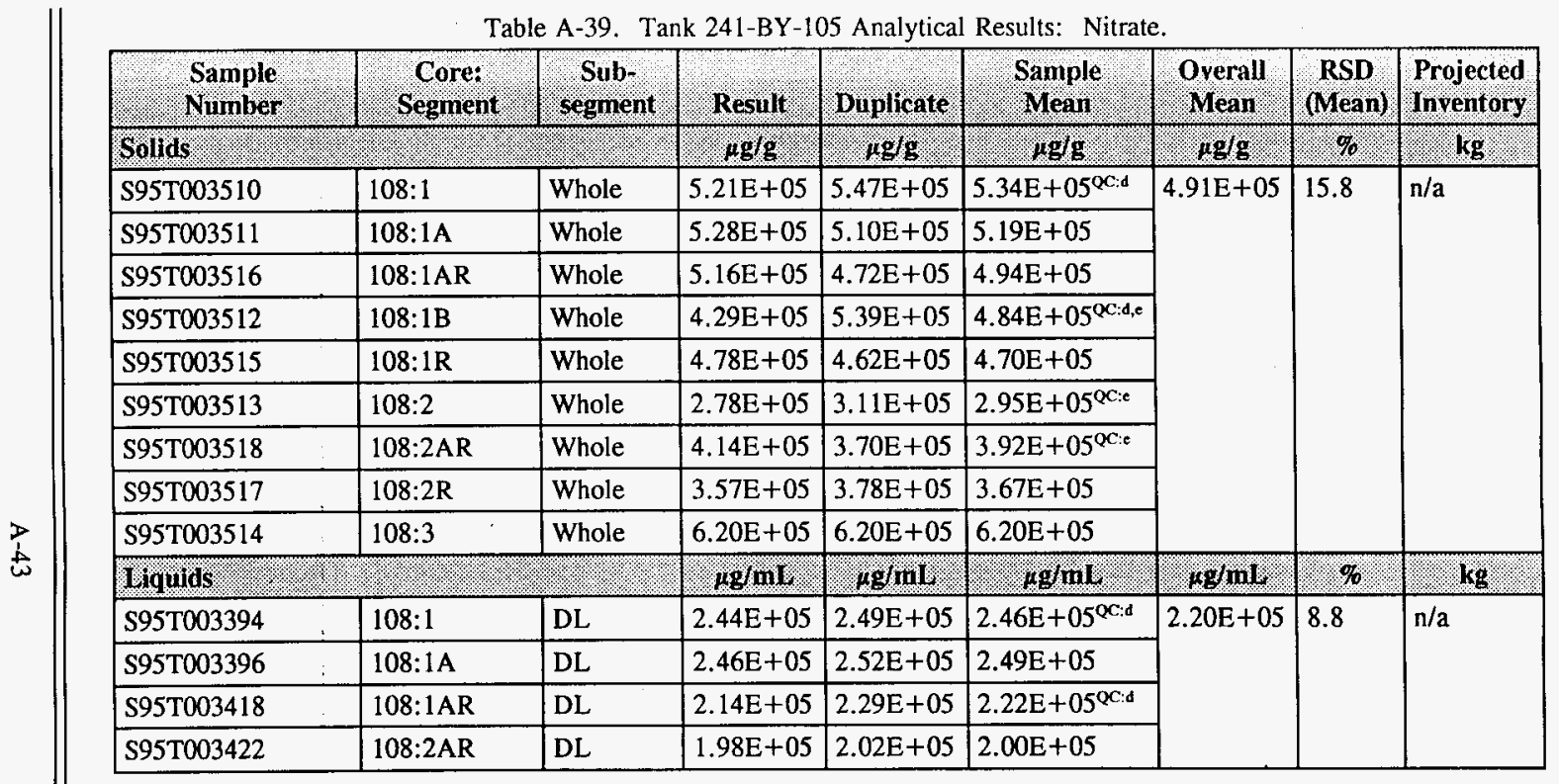


Table A-40. Tank 241-BY-105 Analytical Results: Nitrite.

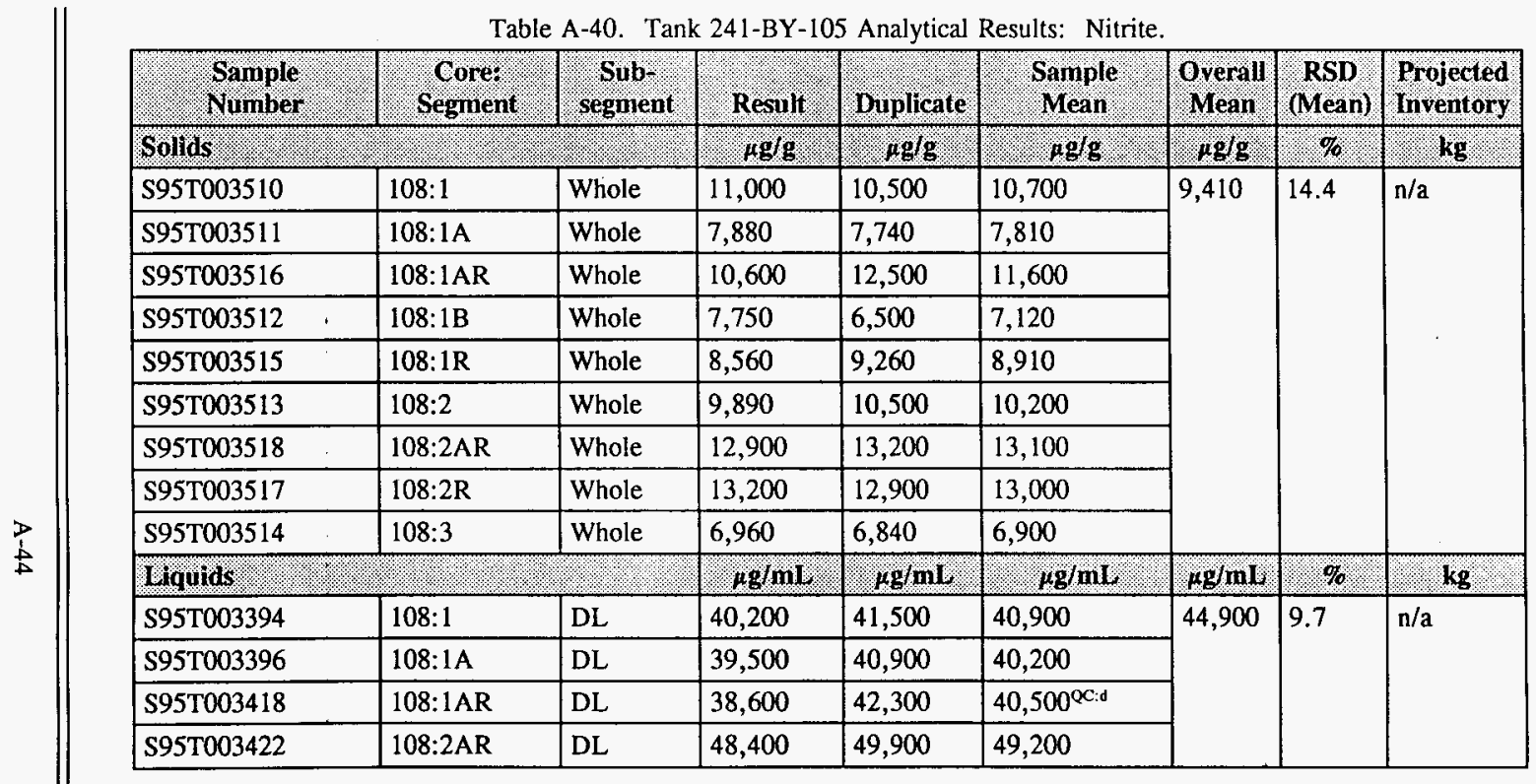


Table A-41. Tank 241-BY-105 Analytical Results: Oxalate.

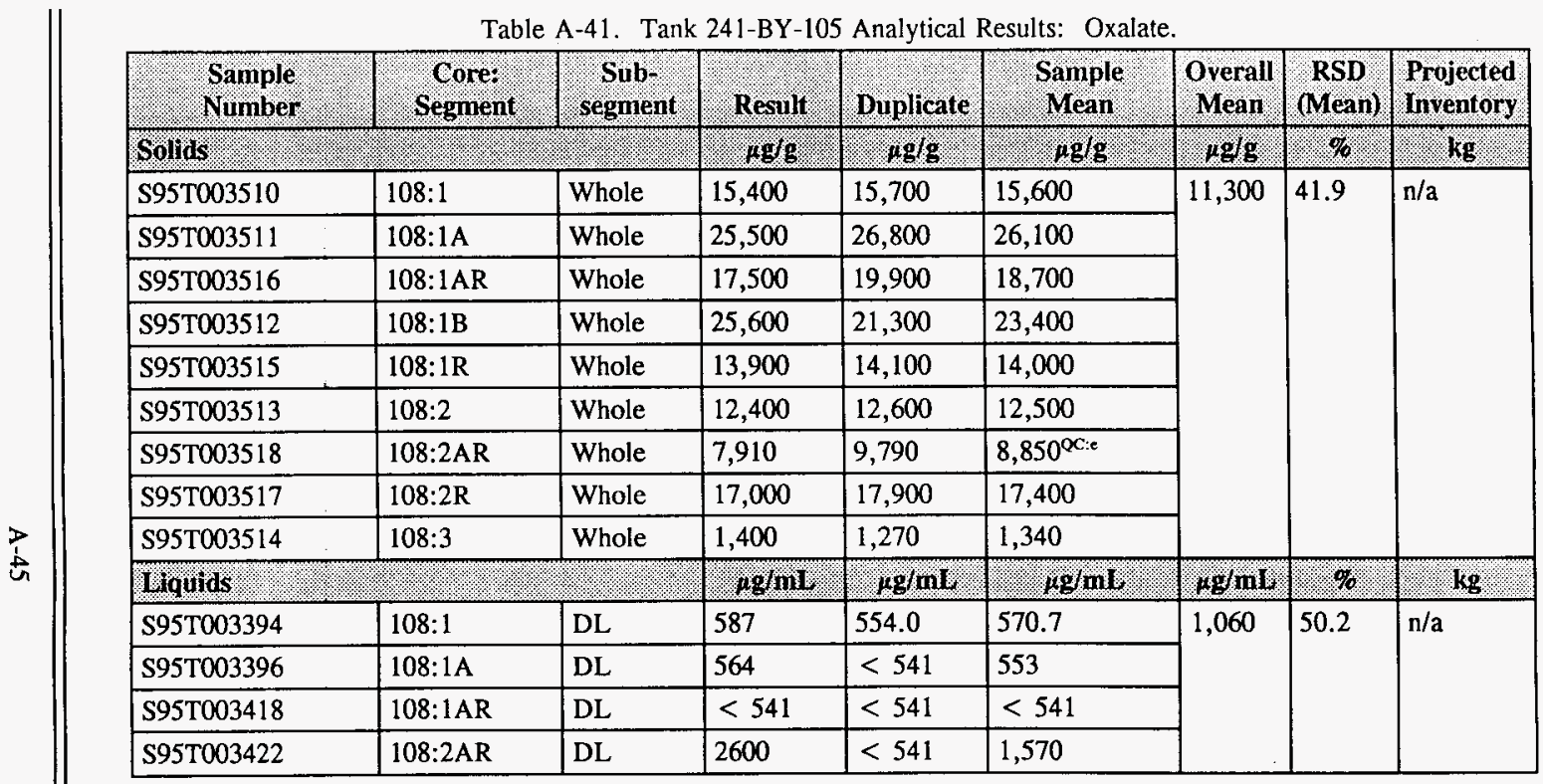


Table A-42. Tank 241-BY-105 Analytical Results: Phosphate.

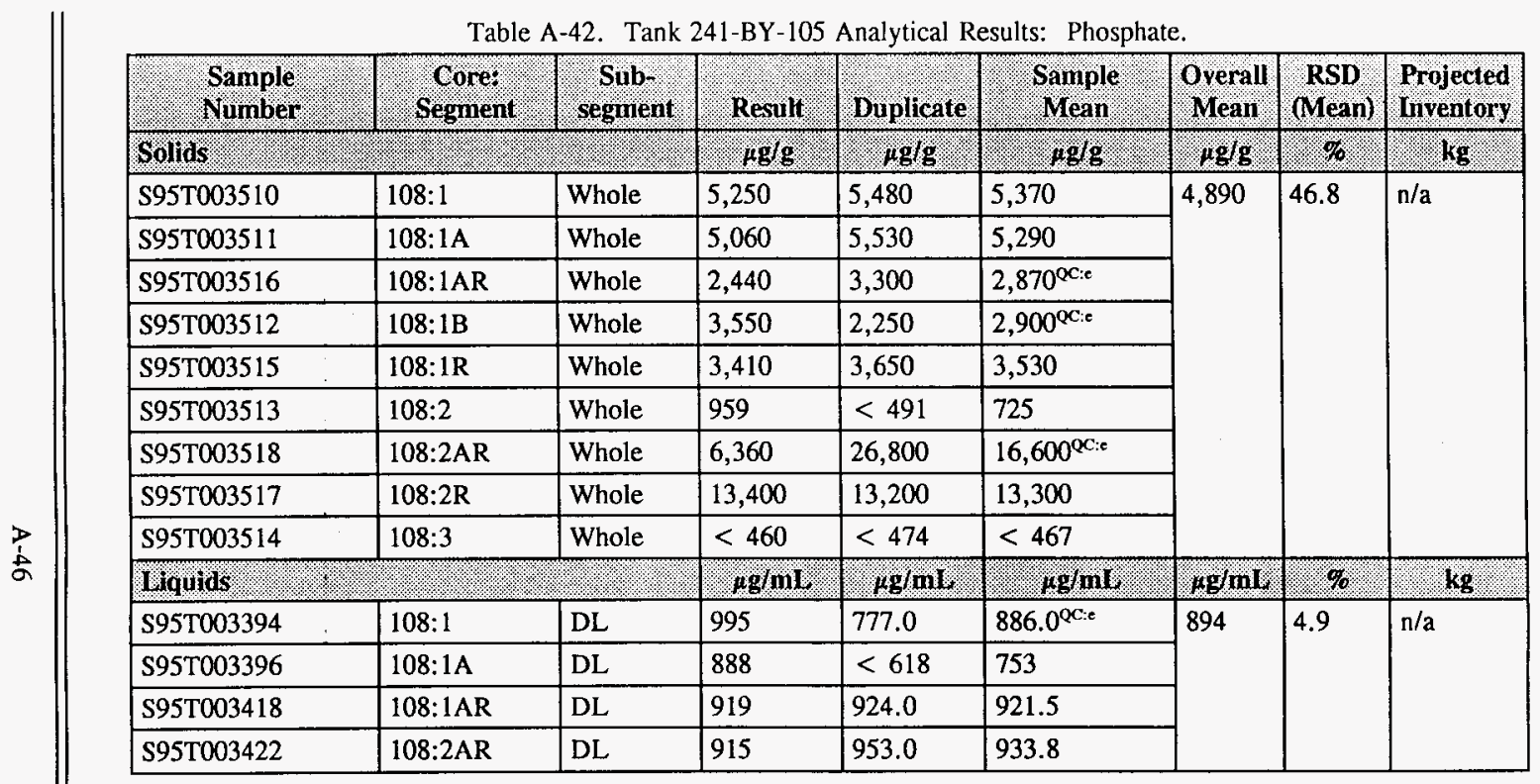


Table A-43. Tank 241-BY-105 Analytical Results: Sulfate.

\begin{tabular}{|c|c|c|c|c|c|c|c|c|}
\hline $\begin{array}{l}\text { Sample } \\
\text { Number } \\
\end{array}$ & $\begin{array}{c}\text { Core: } \\
\text { Segment } \\
\end{array}$ & $\begin{array}{c}\text { Sub- } \\
\text { segment }\end{array}$ & Result: & Duplicate & $\begin{array}{l}\text { Sample } \\
\text { Mean }\end{array}$ & $\begin{array}{c}\text { Overall } \\
\text { Mean }\end{array}$ & $\begin{array}{c}\text { RSD } \\
\text { (Mean) } \\
\end{array}$ & $\begin{array}{l}\text { Projected } \\
\text { Inventory }\end{array}$ \\
\hline \multicolumn{3}{|c|}{ Solids } & $\mu \mathrm{g} / \mathrm{g}$ & $4 \mathrm{~g} / \mathrm{g}$ & $10.98 \mathrm{~g}$ & $\mu \mathrm{g} / \mathrm{g}$ & $1 \%$ & $.4 \mathrm{~kg}$ \\
\hline S95T003510 & $108: 1$ & Whole & 12,300 & 11,800 & 12,000 & \multirow[t]{9}{*}{10,600} & \multirow[t]{9}{*}{36.2} & \multirow[t]{9}{*}{$\mathrm{n} / \mathrm{a}$} \\
\hline S95T003511 & 108:1A & Whole & 21,100 & 21,700 & 21,400 & & & \\
\hline S95T003516 & 108:1AR & Whole & 8,640 & 9,800 & $9,220^{\mathrm{QC:c}}$ & & & \\
\hline S95T003512 & 108:1B & Whole & 9,390 & 8,540 & 8,970 & & & \\
\hline S95T003515 & $108: 1 \mathrm{R}$ & Whole & 13,500 & 13,500 & 13,500 & & & \\
\hline S95T003513 & 108:2 & Whole & 17,000 & 17,600 & 17,300 & & & \\
\hline S95T003518 & 108:2AR & Whole & 14,900 & 15,400 & 15,200 & & & \\
\hline S95T003517 & $108: 2 \mathrm{R}$ & Whole & 18,000 & 18,200 & 18,100 & & & \\
\hline S95T003514 & $108: 3$ & Whole & 1,850 & 2,030 & 1,940 & & & \\
\hline \multicolumn{3}{|c|}{ Vrquids } & $\mu \mathrm{g} / \mathrm{mL}$ & $\mu \mathrm{g} / \mathrm{mil}$ & $\mu \mathrm{g} / \mathrm{mL}$ & $\mu \mathrm{g} / \mathrm{mL}$. & 9. & . \\
\hline S95T003394 & 108:1 & DL & 1,900 & 1,850 & 1,880 & \multirow[t]{4}{*}{1,680} & \multirow[t]{4}{*}{3.4} & \multirow[t]{4}{*}{$n / a$} \\
\hline S95T003396 & 108:1A & DL & 1,630 & 1,800 & 1,710 & & & \\
\hline S95T003418 & 108:1AR & $\mathrm{DL}$ & 1,620 & 1,670 & 1,650 & & & \\
\hline S95T003422 & 108:2AR & $\mathrm{DL}$ & 1,580 & 1,650 & 1,620 & & & \\
\hline
\end{tabular}


Table A-44. Tank 241-BY-105 Analytical Results: Total Alpha.

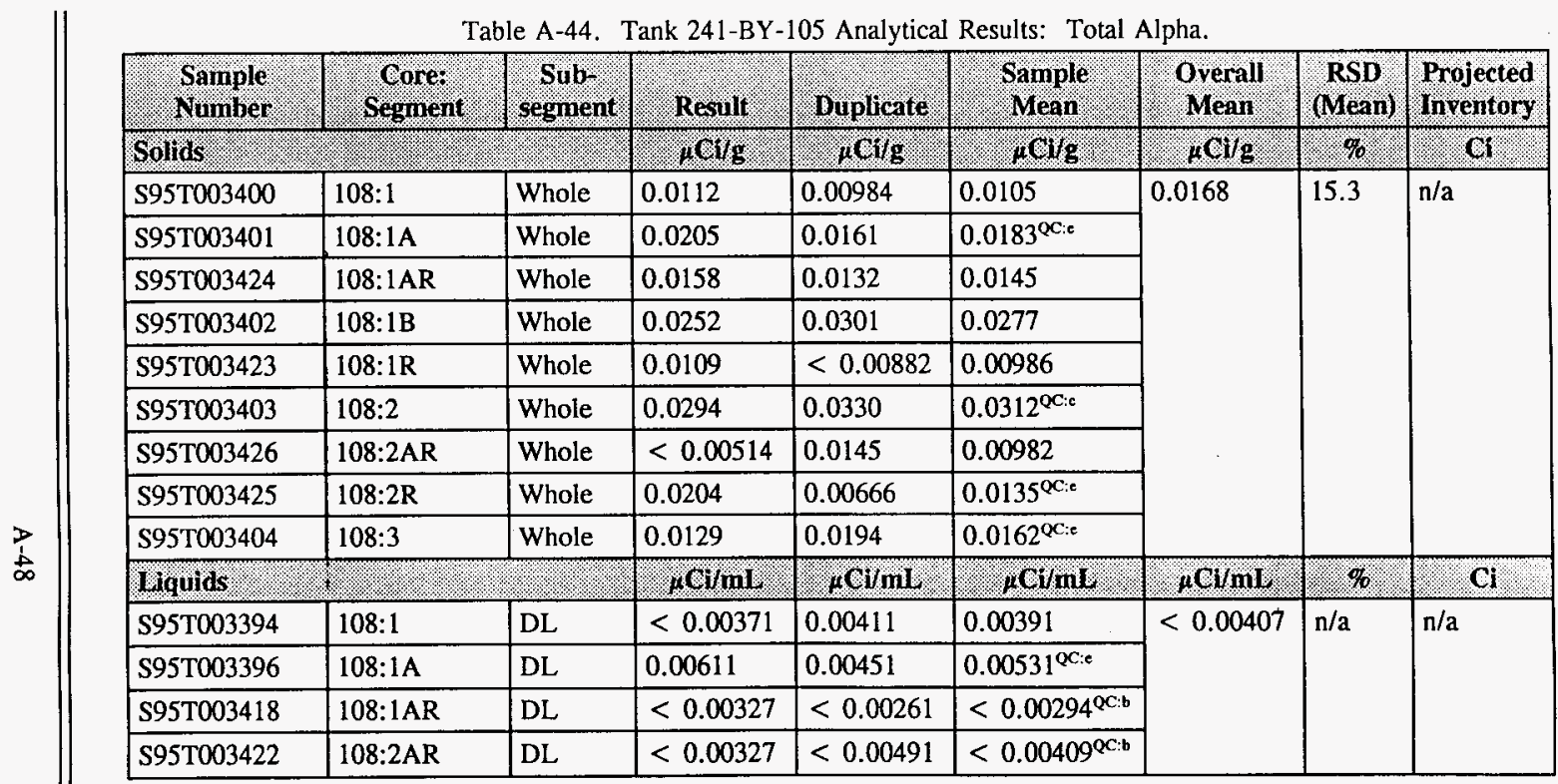


Table A-45. Tank 241-BY-105 Analytical Results: TOC.

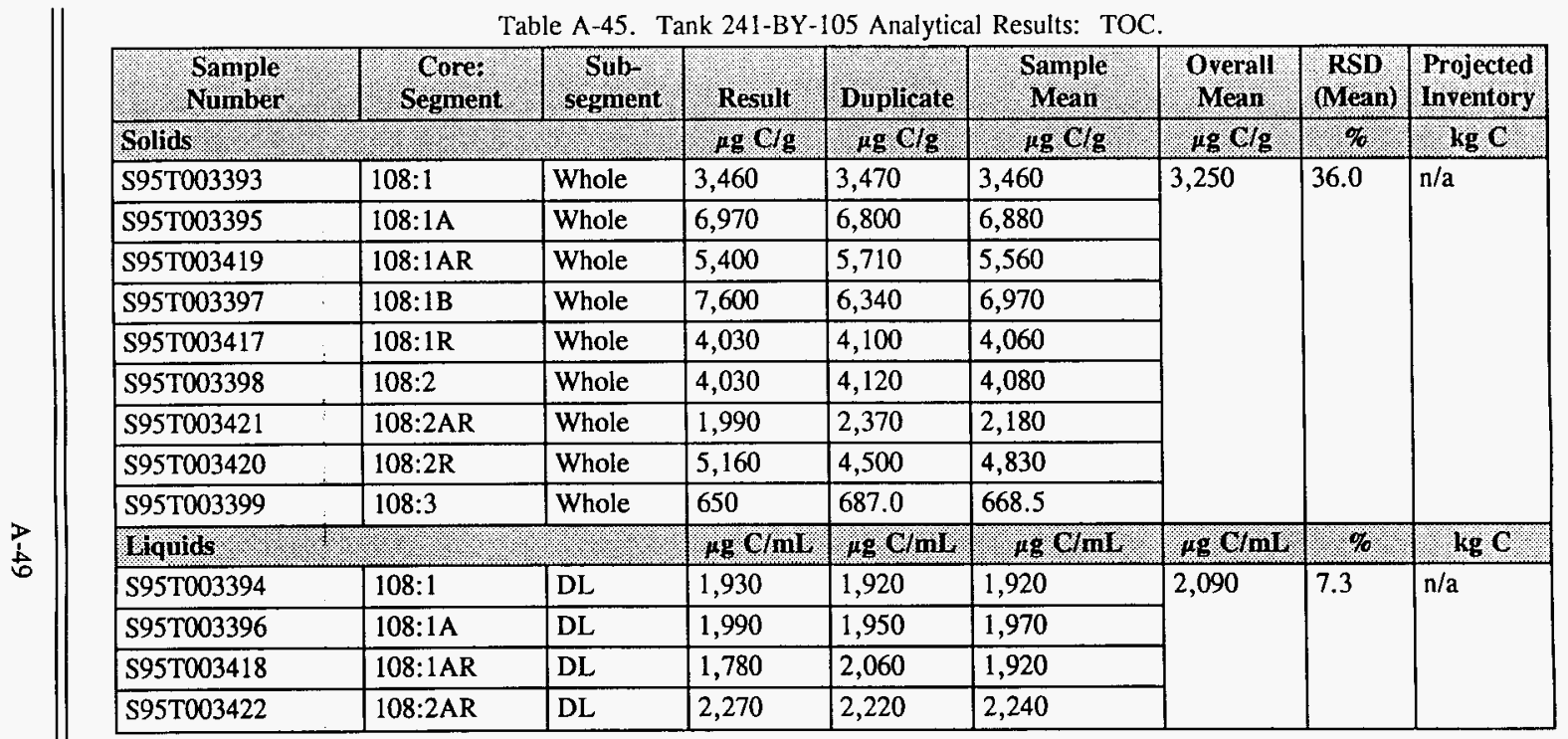

Table A-46. Tank 241-BY-105 Analytical Results: Cyanide.

\begin{tabular}{|c|c|c|c|c|c|c|c|c|}
\hline $\begin{array}{l}\text { Sample } \\
\text { Number }\end{array}$ & Segrnent & segment & Result & Duplicate & $\begin{array}{l}\text { Sample } \\
\text { Mean }\end{array}$ & $\begin{array}{l}\text { Overall } \\
\text { Yean }\end{array}$ & $\begin{array}{c}\text { RSD } \\
\text { (Meail) }\end{array}$ & $\begin{array}{l}\text { Projected } \\
\text { Inventory }\end{array}$ \\
\hline Solids & & & $\mu \mathrm{g} / \mathrm{g}$ & $\mu \mathrm{g} / \mathrm{g}$ & $\mu \mathrm{g} / \mathrm{g}$ & $\mu g / g$ & $\%$ & kg \\
\hline S95T003399 & $108: 3$ & Whole & 3.920 & 5.860 & $4.890^{\mathrm{QC}: c, e}$ & 4.89 & 14.5 & $n / a$ \\
\hline Giquids & & & $17 \mathrm{~g} / \mathrm{ml}$ & $1 \mathrm{~g} / \mathrm{mL}$ & rgini. & $\mu \mathrm{g} / \mathrm{mL}$ & $\%$ & $\mathrm{~kg}$ \\
\hline S95T003418 & 108:1AR & DL & 10.10 & 11.30 & $10.70^{\mathrm{QC:c}}$ & 10.7 & 5.6 & $n / a$ \\
\hline
\end{tabular}


Table A-47. Tank 241-BY-105 Analytical Results: Weight Percent Water. (2 sheets)

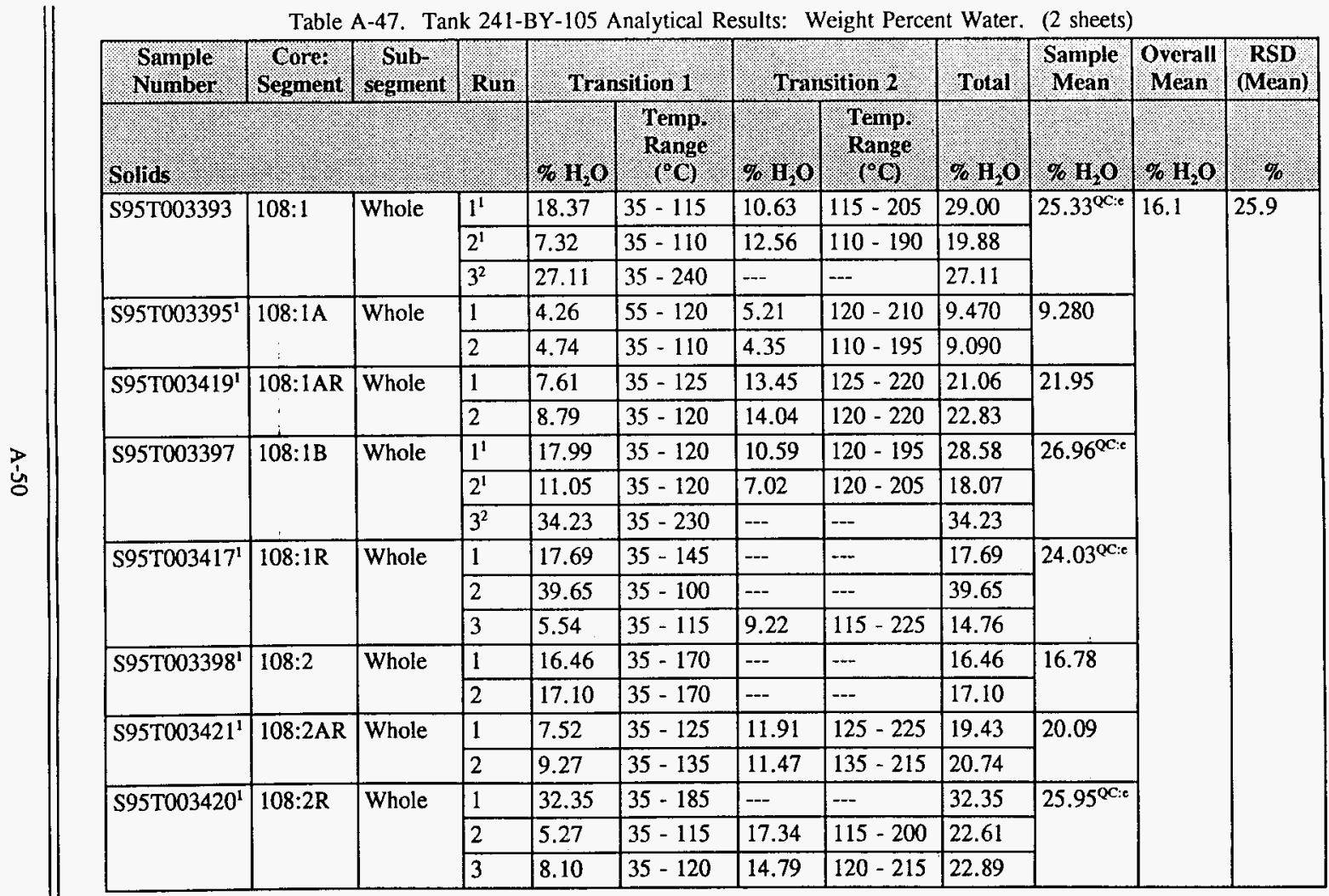


Table A-47. Tank 241-BY-105 Analytical Results: Weight Percent Water. (2 sheets)

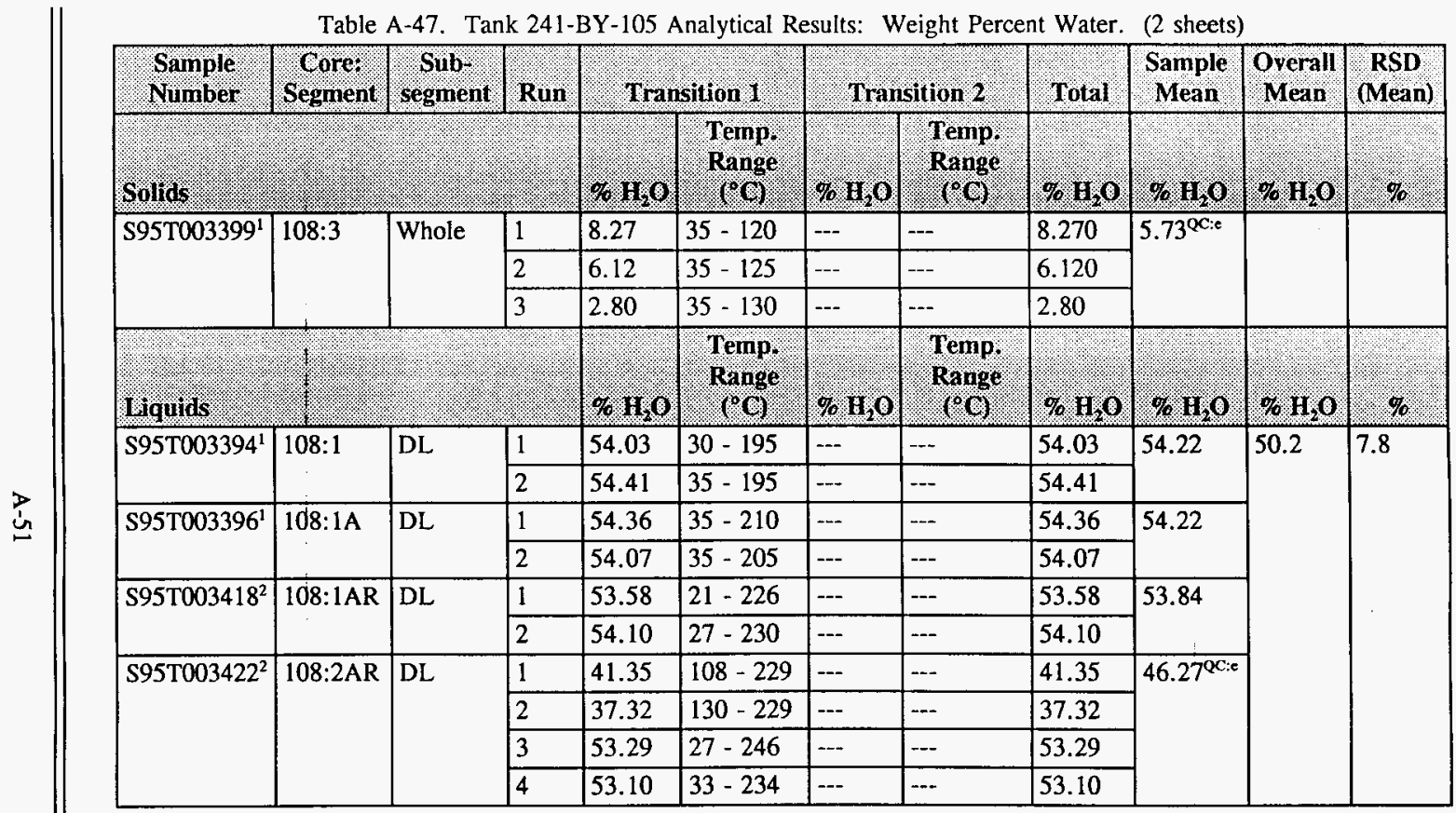

Notes:

'Performed on a Mettler ${ }^{\mathrm{TM}}$ instrument

${ }^{2}$ Performed on a Perkin-Elmer ${ }^{\mathrm{TM}}$ instrument 


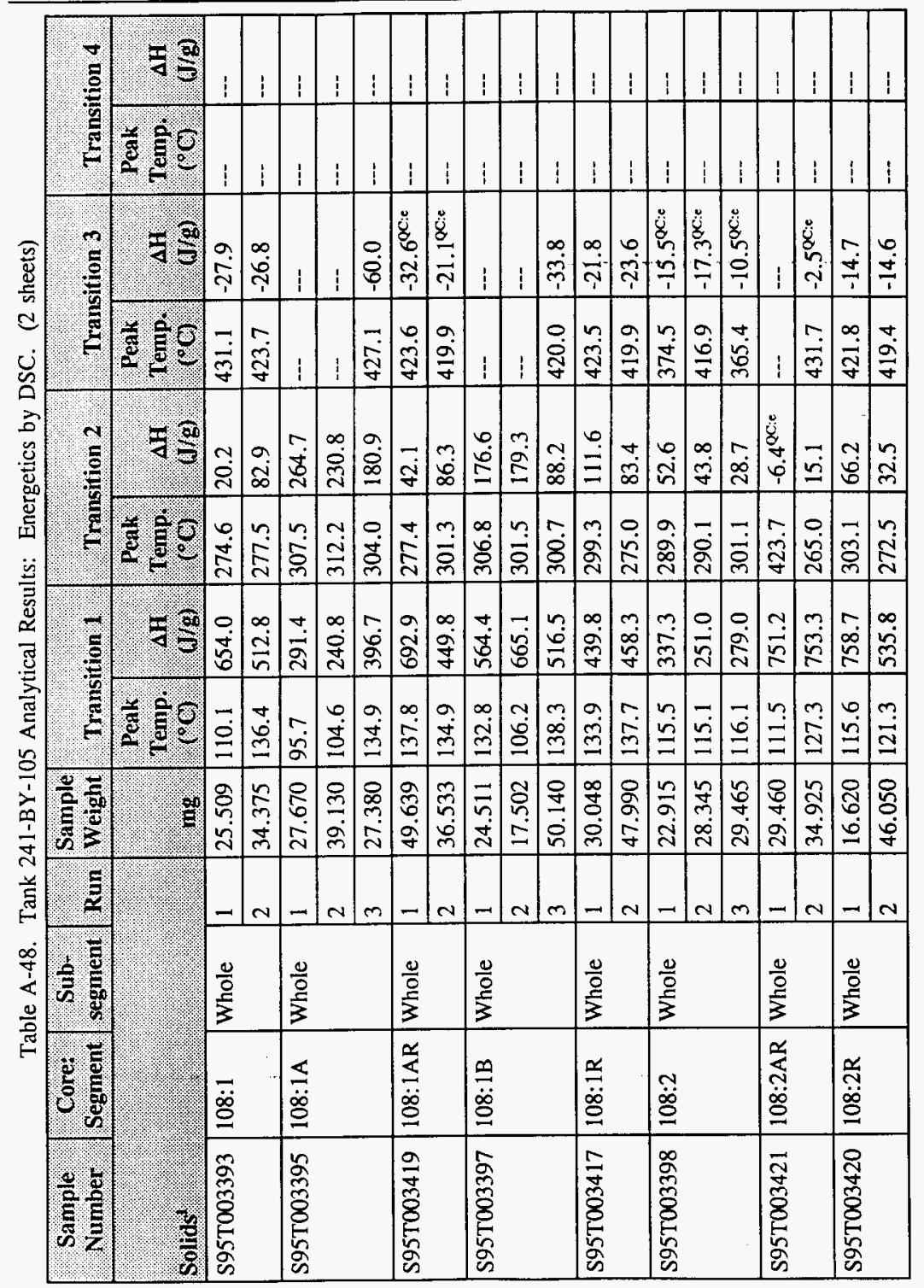


Table A-48. Tank 241-BY-105 Analytical Results: Energetics by DSC. (2 sheets)

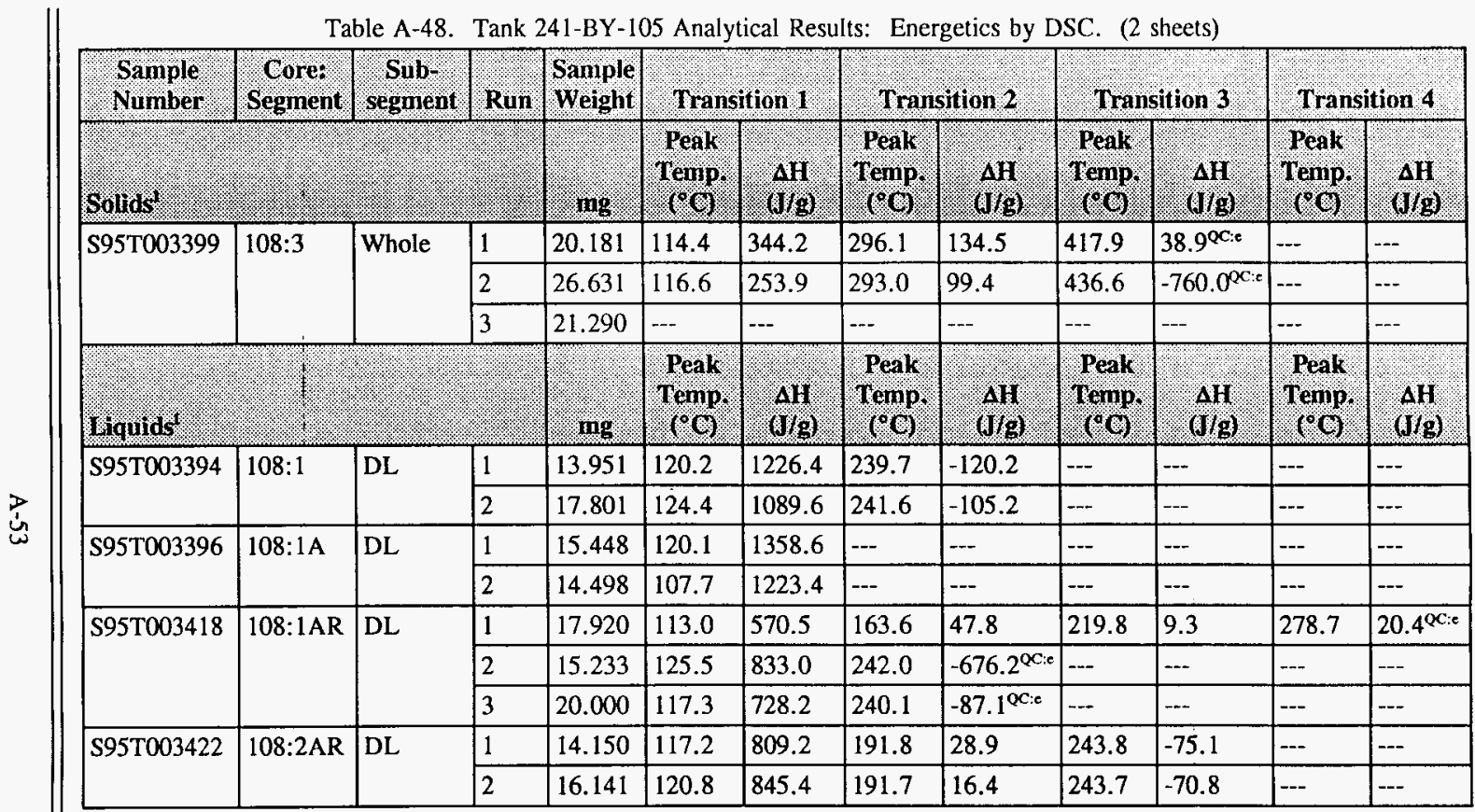

Notes:

$\Delta \mathbf{H}=$ change in enthalpy (negative sign denotes exothermic reaction)

'All analyses performed on a Mettler ${ }^{\mathrm{TM}}$ instrument. 
Table A-49. Tank 241-BY-105 Analytical Results: Bulk Density/Specific Gravity.

\begin{tabular}{|c|c|c|c|c|c|c|c|}
\hline Sample & Sorret & $\begin{array}{l}\text { Sub- } \\
\text { segment }\end{array}$ & Result & Duplicate & Sample & Overall & $\begin{array}{l}\text { RSD } \\
(\text { Mean })\end{array}$ \\
\hline Sollids. & N. & I & $\mathrm{g} / \mathrm{ml}$ & $\mathrm{glml}$ & g/ml & $\mathrm{g} / \mathrm{ml}$ & $\%$ \\
\hline S95T003379 & 108:1 & Whole & 1.970 & 1.900 & 1.935 & \multirow[t]{9}{*}{1.86} & \multirow[t]{9}{*}{1.6} \\
\hline S95T003381 & 108:1A & Whole & 1.970 & 1.980 & 1.975 & & \\
\hline S95T003406 & 108:1AR & Whole & $<0.500$ & $\mathrm{n} / \mathrm{a}$ & $n / a$ & & \\
\hline S95T003383 & 108:1B & Whole & 1.870 & 1.890 & 1.880 & & \\
\hline S95T003405 & 108:1R & Whole & 1.900 & 1.860 & 1.880 & & \\
\hline S95T003384 & $108: 2$ & Whole & $<0.500$ & $n / a$ & $n / a$ & & \\
\hline \$95T003409 & $108: 2 \mathrm{AR}$ & Whole & 1.880 & 1.810 & 1.845 & & \\
\hline S95T003408 & $108: 2 \mathrm{R}$ & Whole & 1.840 & 1.850 & 1.845 & & \\
\hline S95T003385 & $108: 3$ & Whole & 1.830 & $\mathrm{n} / \mathrm{a}$ & $\mathrm{n} / \mathrm{a}$ & & \\
\hline \multicolumn{3}{|l|}{ Wouids. } & $\mathrm{g} / \mathrm{ml}$ & $\mathrm{g} / \mathrm{mi}$ & $\mathrm{g} / \mathrm{ml}$ & $g / \mathbf{m l}$ & $\%$ \\
\hline S95T003394 & 108:1 & $\mathrm{DL}$ & 1.390 & 1.390 & 1.390 & \multirow[t]{4}{*}{1.40} & \multirow[t]{4}{*}{0.3} \\
\hline S95T003396 & 108:1A & $\mathrm{DL}$ & 1.400 & 1.390 & 1.395 & & \\
\hline S95T003418 & 108:1AR & $\mathrm{DL}$ & 1.410 & 1.410 & 1.410 & & \\
\hline S95T003422 & $108: 2 \mathrm{AR}$ & DL & 1.410 & 1.400 & 1.405 & & \\
\hline
\end{tabular}


WHC-SD-WM-ER-598 Rev. 0

APPENDIX B

RESULTS OF HYDROSTATIC HEAD FLUID CONTAMINATION CHECK FOR SINGLE-SHELL TANK 241-BY-105 
WHC-SD-WM-ER-598 Rev. 0

This page intentionally left blank. 


\section{ION CHECK FOR}

\section{SINGLE-SHELL TANK 241-BY-105}

\section{B.1 INTRODUCTION AND ANALYTE TABLE DESCRIPTION}

Appendix B reports the results of the HHF contamination check for the 1995 core sampling event. Lithium and bromide were measured to detect any contamination of the waste samples by the HHF.

The "Sample Number" column in each of the data tables lists the laboratory sample identification number. Sampling rationale, locations, and a description of the sampling event are discussed in Section 3.0.

The "Core:Segment" column specifies the core and segment from which the sample was derived.

The "Subsegment" column specifies "Whole" or "DL," depending on whether the sample analyzed was a whole (solid) segment or drainable liquid from a segment.

The "Result" and "Duplicate" columns are self-explanatory. The "Sample Mean" column lists the average of the result and duplicate values. If the result and duplicate values were both detected, or one of the two values is detected and the other non-detected, then the mean is expressed as a detected value. If the result and duplicate values were both nondetected, then the mean is expressed as a nondetected. The result and duplicate values, as well as the result/duplicate means, are reported in the tables exactly as found in the original laboratory data package. The means may appear to have been rounded up in some cases and down in others. This is because the analytical results in the tables may have fewer significant figures than originally reported, not because the means were incorrectly calculated.

Projected inventories were not calculated for either of the two analytes because they are not believed to be inherent constituents of the waste.

The four quality control parameters assessed on the tank 241-BY-105 samples were standard recoveries, spike recoveries, duplicate analyses (RPDs), and blanks. These were summarized in Section 5.1.2. More specific information is provided in the following appendix tables. Sample and duplicate pairs in which any of the QC parameters were outside their specified limits are superscripted in the "Sample Mean" column as follows:

$\mathrm{QC}: \mathrm{a}$-- indicates that the standard recovery was below the QC range.

$\mathrm{QC}: \mathrm{b}$-- indicates that the standard recovery was above the QC range.

$\mathrm{QC}: \mathrm{c}$-- indicates that the spike recovery was below the QC range.

QC:d -- indicates that the spike recovery was above the QC range.

$\mathrm{QC}: \mathrm{e}$-- indicates that the RPD was greater than the QC limit range.

QC:f - indicates blank contamination. 
Table B-1. Tank 241-BY-105 Hydrostatic Head Fluid Contamination Check: Lithium.

\begin{tabular}{|c|c|c|c|c|c|}
\hline $\begin{array}{l}\text { Sample } \\
\text { Number }\end{array}$ & $\begin{array}{l}\text { Core: } \\
\text { Segrneit }\end{array}$ & $\begin{array}{l}\text { Sub- } \\
\text { segment }\end{array}$ & Result & Duplicate & $\begin{array}{l}\text { Sample } \\
\text { Mean }\end{array}$ \\
\hline Solids & 2. & 4.8. & pg/g & $\mathrm{Mg} / \mathrm{g}$ & $\begin{array}{ll}\mathrm{gg} / \mathrm{g} \\
\end{array}$ \\
\hline S95T003501 & 108:1 & Whole & $<4.320$ & $<3.91$ & $<4.12$ \\
\hline S95T003502 & 108:1A & Whole & $<3.850$ & $<3.89$ & $<3.87$ \\
\hline S95T003507 & 108:1AR & Whole & 12.60 & 18.80 & $15.70^{\mathrm{QC}: \mathrm{e}}$ \\
\hline S95T003503 & 108:1B & Whole & $<3.660$ & $<3.56$ & $<3.61$ \\
\hline S95T003506 & 108:1R & Whole & 69.20 & 79.50 & 74.35 \\
\hline S95T003504 & 108:2 & Whole & $<4.430$ & $<4.69$ & $<4.56$ \\
\hline S95T003509 & $108: 2 \mathrm{AR}$ & Whole & 9.060 & 11.40 & $10.23^{Q C i e}$ \\
\hline S95T003508 & $108: 2 \mathrm{R}$ & Whole & 41.40 & 40.80 & 41.10 \\
\hline S95T003505 & 108:3 & Whole & $<3.730$ & $<3.87$ & $<3.80$ \\
\hline Liquids: & s: & & (ng/nil. & $\mu \mathrm{g} / \mathrm{mL}$ & $18 \mathrm{~m}$ \\
\hline S95T003394 & 108:1 & DL & $<4.010$ & $<4.01$ & $<4.01$ \\
\hline S95T003396 & 108:1A & DL & $<4.010$ & $<4.01$ & $<4.01$ \\
\hline S95T003418 & 108:1 AR & DL & $<4.010$ & $<4.01$ & $<4.01$ \\
\hline S95T003422 & $108: 2 \mathrm{AR}$ & DL & $<4.010$ & $<4.01$ & $<4.01$ \\
\hline
\end{tabular}


Table B-2. Tank 241-BY-105 Hydrostatic Head Fluid Contamination Check: Bromide.

\begin{tabular}{|c|c|c|c|c|c|}
\hline Sample & $\begin{array}{l}\text { Soret } \\
\text { Segnent }\end{array}$ & $\begin{array}{l}\text { Sub- } \\
\text { segment }\end{array}$ & Result & Diplicate & $\begin{array}{l}\text { Sample } \\
\text { Hean }\end{array}$ \\
\hline Solids. & & 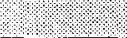 & $2 \mathrm{~g} / \mathrm{g}$ & $4.4 \mathrm{~g} / \mathrm{g}$ & $4 \mathrm{~g} / \mathrm{g}$ \\
\hline S95T003510 & $108: 1$ & Whole & $<2,420$ & $<2,290$ & $<2,360$ \\
\hline S95T003511 & $108: 1 \mathrm{~A}$ & Whole & $<1,630$ & $<1,640$ & $<1,640$ \\
\hline S95T003516 & 108:1AR & Whole & 783 & 817.0 & 799.9 \\
\hline S95T003512 & 108:1B & Whole & $<520$ & $<508$ & $<514$ \\
\hline S95T003515 & $108: 1 \mathrm{R}$ & Whole & 1,060 & 1,120 & 1,090 \\
\hline S95T003513 & $108: 2$ & Whole & $<522$ & $<516$ & $<519$ \\
\hline S95T003518 & 108:2AR & Whole & $<2,270$ & $<2,260$ & $<2,270$ \\
\hline S95T003517 & $108: 2 \mathrm{R}$ & Whole & $<2,320$ & 3,280 & 2,800 \\
\hline S95T003514 & $108: 3$ & Whole & $<484$ & $<497$ & $<491$ \\
\hline Lquids & & & $4 \mathrm{~g} / \mathrm{mL}$ & $.4 \mathrm{~g} / \mathrm{ml}$ & $1.4 \mathrm{~g} / \mathrm{ml}$ \\
\hline S95T003394 & 108:1 & DL & $<649$ & $<649$ & $<649$ \\
\hline S95T003396 & 108:1A & $\mathrm{DL}$ & $<649$ & $<649$ & $<649$ \\
\hline S95T003418 & 108:1AR & $\mathrm{DL}$ & 1,110 & 1,150 & 1,130 \\
\hline S95T003422 & $108: 2 \mathrm{AR}$ & $\mathrm{DL}$ & 685 & 673.0 & 679.1 \\
\hline
\end{tabular}


WHC-SD-WM-ER-598 Rev. 0

This page intentionally left blank. 
WHC-SD-WM-ER-598 Rev. 0

\begin{abstract}
APPENDIX C
MARCH 1995 GRAB SAMPLING RESULTS
\end{abstract}

C-1 
WHC-SD-WM-ER-598 Rev. 0

This page intentionally left blank. 


\section{C.0 MARCH 1995 GRAB SAMPLING RESULTS}

Table C-1 presents the historical analytical results from two grab samples collected from tank 241-BY-105 in March 1995. The samples were reported as having no organic layer and having approximately $2 \%$ settled solids.

Table C-1. Tank 241-BY-105 March 1995 Grab Sampling Results. (2 sheets)

\begin{tabular}{|c|c|c|c|c|}
\hline Sample Number & Waryte & Result & Buplicate & Sample Mean \\
\hline 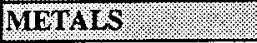 & & $\% 4 \mathrm{~g} / \mathrm{mL}$ & $6.9 \mathrm{gmi}$ & $1.9 / \mathrm{m}$ \\
\hline S95T000450 & \multirow[t]{2}{*}{ Aluminum } & 6,130 & 6,140 & 6,135 \\
\hline S95T000451 & & 6,110 & 6,130 & 6,120 \\
\hline S95T000450 & \multirow[t]{2}{*}{ Iron } & $<20$ & $<20$ & $<20$ \\
\hline S95T000451 & & $<20.0$ & $<20$ & $<20$ \\
\hline S95T000450 & \multirow[t]{2}{*}{ Sodium } & $1.87 \mathrm{E}+05$ & $1.86 \mathrm{E}+05$ & $1.865 \mathrm{E}+05$ \\
\hline S95T000451 & & $1.80 \mathrm{E}+05$ & $1.81 \mathrm{E}+05$ & $1.805 E+05$ \\
\hline \multicolumn{2}{|l|}{ ANIONS } & mglnI & $1.6 \mathrm{~g} / \mathrm{mL}$ & 1/. $/ \mathrm{g}$ mil \\
\hline S95T000450 & \multirow[t]{2}{*}{ Chloride } & 2,080 & 2,070 & 2,080 \\
\hline S95T000451 & & 2,080 & 2,150 & 2,120 \\
\hline S95T000450 & \multirow[t]{2}{*}{ Flouride } & 802 & 787 & 794 \\
\hline \$95T000451 & & 801 & 830 & 816 \\
\hline S95T000450 & \multirow[t]{2}{*}{ Nitrate } & $2.95 \mathrm{E}+05$ & $2.90 \mathrm{E}+05$ & $2.92 \mathrm{E}+05$ \\
\hline S95T000451 & & $3.10 \mathrm{E}+05$ & $2.98 \mathrm{E}+05$ & $3.04 \mathrm{E}+05$ \\
\hline S95T000450 & \multirow[t]{2}{*}{ Nitrite } & 26,800 & 26,400 & 26,600 \\
\hline S95T000451 & & 26,300 & 27,000 & 26,600 \\
\hline S95T000450 & \multirow[t]{2}{*}{ Phosphate } & $<2,647$ & $<2,647$ & $<2,647$ \\
\hline S95T000451 & & $<2,647$ & $<2,647$ & $<2,647$ \\
\hline S95T000450 & \multirow[t]{2}{*}{ Sulfate } & $<3,528$ & $<3,528$ & $<3,528$ \\
\hline S95T000451 & & $<3,528$ & $<3,528$ & $<3,528$ \\
\hline S95T000450 & \multirow[t]{2}{*}{ Hydroxide } & 11,600 & 11,900 & 11,800 \\
\hline S95T000451 & & 11,700 & 12,100 & 11,900 \\
\hline RADIONUCHIDES & (1. & MQVml & $.2 \mathrm{QVu}$ & 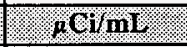 \\
\hline S95T000450 & \multirow[t]{2}{*}{ Americium-241 } & $<2.56 \mathrm{E}-04$ & $<2.46 \mathrm{E}-04$ & $<2.51 \mathrm{E}-04$ \\
\hline S95T000451 & & $<2.99 \mathrm{E}-04$ & $<2.60 \mathrm{E}-04$ & $<2.80 \mathrm{E}-04$ \\
\hline S95T000450 & \multirow[t]{2}{*}{ Cesium-137 } & 85.2 & 85.3 & 85.2 \\
\hline S95T000451 & & 89.7 & 89.8 & 89.8 \\
\hline S95T000450 & \multirow[t]{2}{*}{ Plutonium-239/240 } & $5.07 \mathrm{E}-05$ & $4.09 \mathrm{E}-05$ & 4.58E-05 \\
\hline S95T000451 & & $3.80 \mathrm{E}-05$ & $<7.27 \mathrm{E}-05$ & $5.54 \mathrm{E}-05$ \\
\hline
\end{tabular}


Table C-1. Tank 241-BY-105 March 1995 Grab Sampling Results. (2 sheets)

\begin{tabular}{|c|c|c|c|c|}
\hline Sample Number: & Analyte & Result & Duplicate & Sample Mean \\
\hline \multicolumn{2}{|c|}{ RADIONUCYIDES (Eont d) : : } & $\mu \mathrm{CV} / \mathrm{ml}$. & ICirni. & $\mu \mathrm{Cl} / \mathrm{ml}$ \\
\hline S95T000450 & \multirow[t]{2}{*}{ Strontium-89/90 } & 0.158 & 0.163 & 0.161 \\
\hline S95T000451 & & 0.155 & 0.162 & 0.159 \\
\hline \multicolumn{2}{|c|}{ CARBON } & $\mu \mathrm{g}$ ClmL & $10 \mathrm{~g} / \mathrm{mL}$ & If Clmil \\
\hline S95T000450 & \multirow[t]{2}{*}{ TIC } & 13,300 & 13,300 & 13,300 \\
\hline S95T000451 & & 14,700 & 15,000 & 14,800 \\
\hline S95T000450 & \multirow[t]{2}{*}{ TOC } & 1,660 & 1,580 & 1,620 \\
\hline S95T000451 & & 1,720 & 1,700 & 1,710 \\
\hline \multicolumn{5}{|c|}{ PHYSICAI PROPERTIES: } \\
\hline S95T000450 & \multirow{2}{*}{$\begin{array}{l}\text { Weight percent } \\
\text { water }\end{array}$} & 55.21 & 55.36 & 55.28 \\
\hline S95T000451 & & 56.34 & 55.90 & 56.12 \\
\hline S95T000450 & \multirow[t]{2}{*}{$\operatorname{DSC}(\mathrm{J} / \mathrm{g})$} & 0 & 0 & 0 \\
\hline S95T000451 & & 0 & 0 & 0 \\
\hline S95T000450 & \multirow[t]{2}{*}{$\mathrm{pH}$} & 13.50 & 13.56 & 13.53 \\
\hline S95T000451 & & 13.55 & 13.54 & 13.54 \\
\hline S95T000450 & \multirow[t]{2}{*}{$\mathrm{SpG}$} & 1.32 & 1.33 & 1.325 \\
\hline S95T000451 & & 1.08 & 1.20 & 1.140 \\
\hline S95T000450 & \multirow[t]{2}{*}{ Volume $\%$ solids } & 2.00 & $\mathrm{n} / \mathrm{a}$ & $\mathrm{n} / \mathrm{a}$ \\
\hline S95T000451 & & 2.1 & $n / a$ & $\mathrm{n} / \mathrm{a}$ \\
\hline S95T000450 & \multirow{2}{*}{$\begin{array}{l}\text { Organic volume } \\
\text { present }(\mathrm{mL})\end{array}$} & 0 & $n / a$ & $\mathrm{n} / \mathrm{a}$ \\
\hline S95T000451 & & 0 & $\mathrm{n} / \mathrm{a}$ & $n / a$ \\
\hline
\end{tabular}




\begin{tabular}{|c|c|c|c|c|c|}
\hline To & \multirow{2}{*}{\multicolumn{3}{|c|}{ From }} & \multicolumn{2}{|l|}{ Page 3 of 4} \\
\hline Distribution & & & & Date & $08 / 14 / 96$ \\
\hline \multicolumn{4}{|l|}{ Project Title/Work Order } & \multicolumn{2}{|c|}{ EDT No. EDT-617521 } \\
\hline \multicolumn{4}{|c|}{$\begin{array}{l}\text { Tank Characterization Report for Single-She } 11 \text { Tank 241-BY-105. } \\
\text { WHC-SD-WM-ER-598. Rev. } 0\end{array}$} & ECN No. $\quad \mathrm{N} / \mathrm{f}$ & \\
\hline Name & MSIN & $\begin{array}{c}\text { Text } \\
\text { With All } \\
\text { Attach. }\end{array}$ & Text Only & $\begin{array}{l}\text { Attach./ } \\
\text { Appendix } \\
\text { Only }\end{array}$ & $\begin{array}{l}\text { EDT/ECN } \\
\text { Only }\end{array}$ \\
\hline
\end{tabular}

\section{ONSITE}

Department of Energy - Richland Operations
J. F. Thompson
W. S. Liou
N. W. Willis

$\begin{array}{ll}57-54 & x \\ 57-54 & x \\ 57-54 & X\end{array}$

ICF-Kaiser Hanford Company
R. L. Newe 17
S3-09
$X$

Pacific Northwest Laboratory

N. G. Colton

* J. R. Gormsen

S. A. Hartley

J. G. Hill

G. J. Lumetta

A. F. Noonan

Westinghouse Hanford Company

H. Babad

D. A. Barnes

G. R. Bloom

W. L. Cowley

L. A. Diaz

G. L. Dunford

*E. J. Eberlein

D. B. Engelman

J. G. Field

J. S. Garfield

*J. D. Guberski

D. L. Herting

D. C. Hetzer

$G$. Jansen

G. D. Johnson

T. J. Kelley

N. W. Kirch

M. J. Kupfer

J. E. Meacham

$\begin{array}{ll}K 3-75 & x \\ K 7-28 & \\ K 5-12 & x \\ K 7-94 & X \\ \text { P7 }-25 & X \\ K 9-81 & X\end{array}$

$57-14$

R1 -80

H5-61

A3-37

T6-06

A2-34

$\mathrm{R} 2-12$

RI-49

R2-12

H5 -49

R1-51

T6-09

S6-31

H6-33

S7 -15

S7 -21

R2-11

H5 - 49

S7- 15

$x$

$x$
$x$

X

$x$

$x$

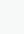




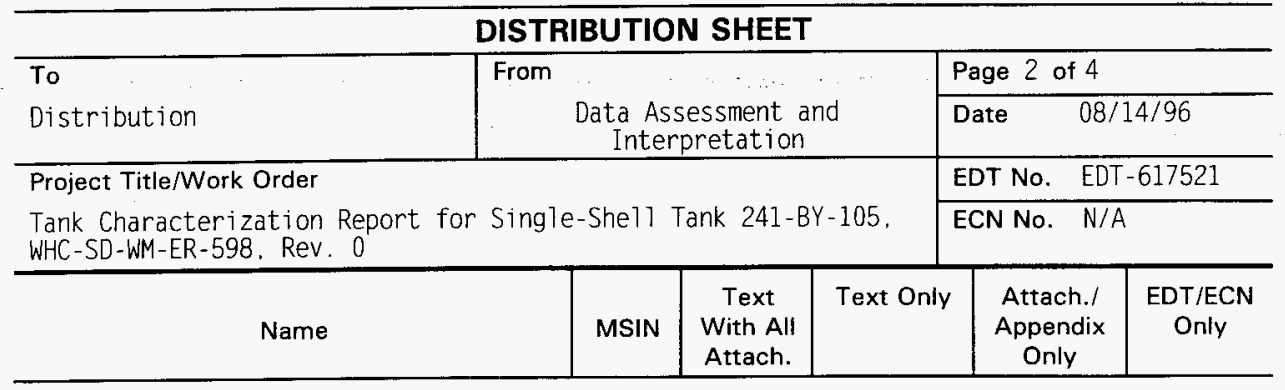

SAIC

20300 Century Boulevard. Suite 200-B

Germantown. MD 20874

H. Sutter

555 Quince Orchard Rd., Suite 500

Gaithersburg, MD 20878

P. Szerszen

$X$

LoS Alamos Laboratory

CST-14 MS-J586

P. 0. Box 1663

Los Alamos. NM 87545

S. F. Agnew (4)

$x$

Los Alamos Technical Associates

T. T. Tran

B1 - 44

$x$

Ogden Environmental

101 East Wel Tsian Way

Richland. WA 99352

R. J. Anema

$x$

$\mathrm{CH} 2 \mathrm{M} \mathrm{Hi} 11$

P. O. Box 91500

Bellevue. WA 98009-2050

M. McAfee

$x$

Tank Advisory Panel

102 Windham Road

Oak Ridge. TN 37830

D. 0. Campbe17

$x$ 


\section{DISTRIBUTION SHEET}

\begin{tabular}{|c|c|c|c|c|c|}
\hline To & \multirow{2}{*}{\multicolumn{3}{|c|}{$\begin{array}{c}\text { Data Ass } \\
\text { Inter }\end{array}$}} & \multicolumn{2}{|l|}{ Page 1 of 4} \\
\hline Distribution & & & & Date & $08 / 14 / 96$ \\
\hline \multicolumn{4}{|l|}{ Project Title/Work Order } & \multicolumn{2}{|c|}{ EDT No. EDT-617521 } \\
\hline \multicolumn{4}{|c|}{$\begin{array}{l}\text { Tank Characterization Report for Single-She11 Tank 241-BY-105. } \\
\text { WHC-SD-WM-ER-598, Rev. } 0\end{array}$} & \multicolumn{2}{|c|}{ ECN No. $\quad \mathrm{N} / \mathrm{A}$} \\
\hline Name & MSIN & $\begin{array}{c}\text { Text } \\
\text { With All } \\
\text { Attach. }\end{array}$ & Text Only & $\begin{array}{l}\text { Attach./ } \\
\text { Appendix } \\
\text { Only }\end{array}$ & $\begin{array}{l}\text { EDT/ECN } \\
\text { Only }\end{array}$ \\
\hline
\end{tabular}

OFFSITE

Sandia National Laboratory

P.0. Box 5800

MS-0744, Dept. 6404

Albuquerque, NM 87815

D. Powers

Nuclear Consulting Services Inc.

P. 0. Box 29151

Columbus, OH 43229-01051

J. L. Kovach

Chemical Reaction Sub-TAP

P. 0. Box 271

Lindsborg, KS 67456

B. C. Hudson

Tank Characterization Panel

Senior Technical Consultant Contech

7309 Indian School Road

Albuquerque, NM 87110

]. Arvisu

U. S. Department of Enerqy - Headquarters

Office of Environmental Restoration and Waste Management EM-563

12800 Middlebrook Road

Germantown. MD 20874

J. A. Poppitti

$x$

Jacobs Engineering Group

B5-36

$x$ 


\begin{tabular}{|c|c|c|c|c|c|}
\hline \multicolumn{6}{|c|}{ DISTRIBUTION SHEET } \\
\hline To & \multirow{2}{*}{\multicolumn{3}{|c|}{ From }} & \multicolumn{2}{|c|}{ Page 4 of 4} \\
\hline Distribution & & & & \multicolumn{2}{|c|}{ Date $\quad 08 / 14 / 96$} \\
\hline \multicolumn{4}{|c|}{ Project Title/Work Order } & \multicolumn{2}{|c|}{ EDT No. EDT-617521 } \\
\hline \multicolumn{4}{|c|}{$\begin{array}{l}\text { Tank Characterization Report for Single-Shel1 Tank 241-BY-105. } \\
\text { WHC-SD-WM-ER-598. Rev. } 0\end{array}$} & N No. $\quad \mathrm{N} / \mathrm{A}$ & \\
\hline Name & MSIN & $\begin{array}{c}\text { Text } \\
\text { With All } \\
\text { Attach. }\end{array}$ & Text Only & $\begin{array}{l}\text { Attach./ } \\
\text { Appendix } \\
\text { Only }\end{array}$ & $\begin{array}{l}\text { EDT/ECN } \\
\text { Only }\end{array}$ \\
\hline
\end{tabular}

Westinghouse Hanford Company continued

W. C. Miller

C. T. Narquis

D. E. Place

D. A. Reynolds

L. M. Sasaki (2)

L. W. Shelton, Jr.

B. C. Simpson

G. L. Troyer

L. R. Webb

K. A. White

Ffic (Fank-Farm Information-Center)

Central Files

EDMC

ERC (Environmental Resource Center)

-OSTI $(-2)$

TCRC (10)

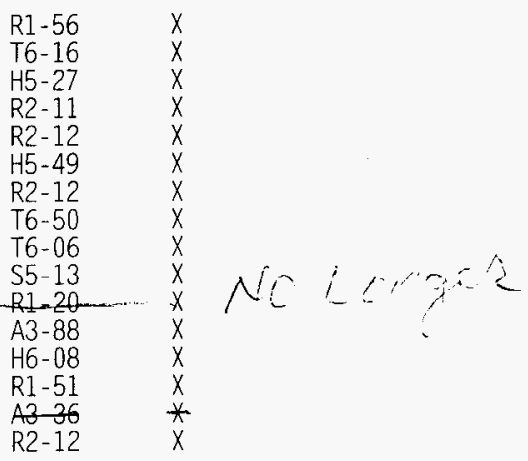

